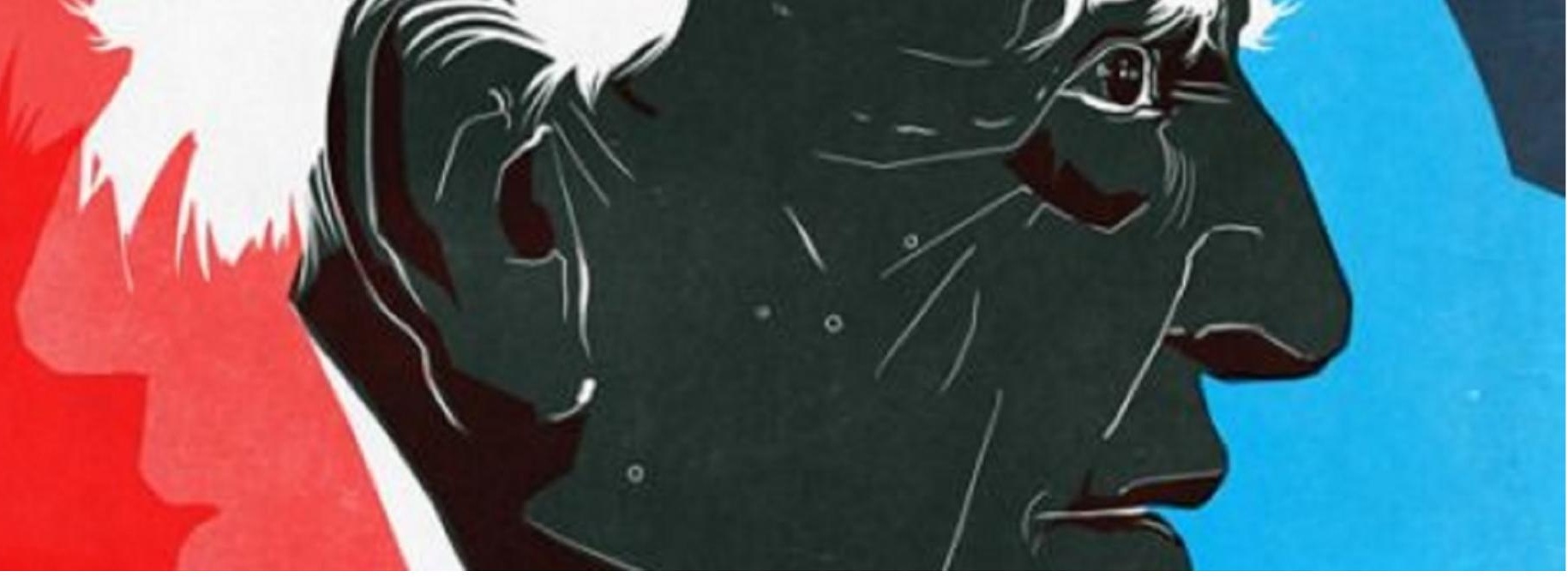

\title{
Abstract:
}

\section{En Torno al Concepto de Bildung en Gadamer - On the concept of Bildung in Gadamer}

$\begin{aligned} \text { Authors: } & \text { Luis Enrique Silva Vieira } \\ \text { Submitted: } & \text { 4. June } 2020 \\ \text { Published: } & \text { 15. June } 2020 \\ \text { Volume: } & 7 \\ \text { Issue: } & 3 \\ \text { Affiliation: } & \text { Facultad de Humanidades y Educación, Universidad Central de } \\ & \text { Venezuela; Caracas Venezuela. } \\ \text { Languages: } & \text { Spanish, Castilian } \\ \text { Keywords: } & \text { Gadamer, Hegel, Bildung, hermeneutics, ethical-political scope. } \\ \text { Categories: } & \text { Humanities, Social Sciences and Law } \\ \text { DOl: } & \text { 10.17160/josha.7.3.680 }\end{aligned}$

When undertaking a hermeneutic-philosophical discourse, centered on the notion of Bildung or human formation, it emerges as an epistemic objective to provide meaningful explanations in the field of the Sciences of the Spirit. Here, Hans-Georg Gadamer has had a fruitful philosophical innovation that affects both the understanding of man and ethics and politics. This research on his contributions to the Bildung is divided into two questions. In the theoretical field: Is it true that Gadamer gives us an original version of the Bildung that can be said to exceed those conceived by the philosophers of the German tradition? Is its universality such that it can be applied to other realities outside the "Heritage of Europe"? In the field of application: Does your version of the Bildung have any significant ethical or political relevance or incidence in today's society? Later, we will analyze the Hegelian perspective of formation as a process focused on the category of "ascent to universality". Both parts seek to establish the fundamental theoretical background from which Gadamer drew for the elaboration of his hermeneutics. We will present those revealina theoretical-practical contributions into the spectrum of Bilduna from the humanistic tradition.

\section{JOSHA \\ Journal of Science, Humanities and Arts}




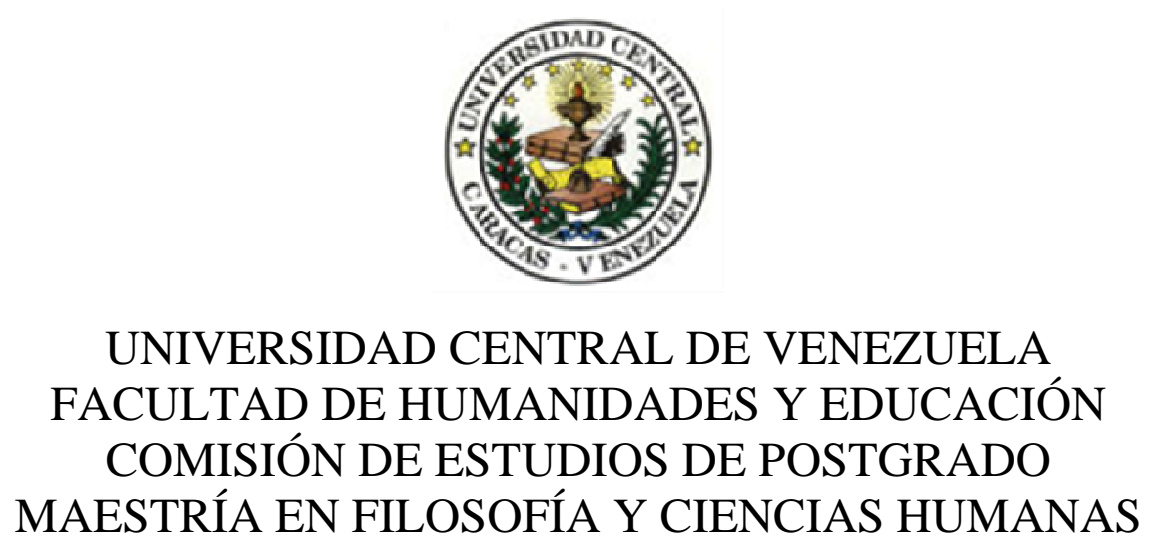

\section{EN TORNO AL CONCEPTO DE BILDUNG EN GADAMER FUENTES, ORIGINALIDAD Y ALCANCE ÉTICO-POLÍTICO}

AUTOR: Lic. Luis Enrique Silva Viera

Caracas, septiembre 2019 
UNIVERSIDAD CENTRAL DE VENEZUELA FACULTAD DE HUMANIDADES Y EDUCACIÓN DIRECCIÓN DE ESTUDIOS DE POSTGRADO ÁREA FILOSOFÍA

MAESTRÍA EN FILOSOFÍA Y CIENCIAS HUMANAS

\section{EN TORNO AL CONCEPTO DE BILDUNG EN GADAMER FUENTES, ORIGINALIDAD Y ALCANCE ÉTICO-POLÍTICO}

Autor: Lic. Luis Enrique Silva Viera C.I. 6.361 .828

Trabajo que se presenta para optar al grado de Magister Scientiarum en Filosofía

Mención: Filosofía y Ciencias Humanas

Tutor

Prof. MSc. Jesús Ojeda 


\section{AGRADECIMIENTOS}

En primer lugar, agradezco a Dios. Le doy gracias a mis padres ausentes, los amo infinitamente. A mis hermanos, por ser parte fundamental en mi vida; a ellos y sólo a ellos dedico este trabajo de investigación. Vaya a todos mi infinita gratitud por tener tanta paciencia ante las adversidades.

A la Facultad de Humanidades y Educación, al Instituto de Filosofía de la Universidad Central de Venezuela y, específicamente, a sus profesores que fueron luz durante mis estudios filosóficos.

Mención especial al profesor Gonzalo León por su inestimable enseñanza y sus consejos en mi arduo camino universitario.

Esta investigación ha sido posible gracias a la atenta lectura, a las muy acertadas observaciones y necesarias sugerencias de mi tutor el Prof. MSc. Jesús Ojeda, sin su apoyo y asesoría jamás hubiera logrado concluirla. A él mi más sinceras consideraciones y eterno agradecimiento.

A mis queridos amigos, profesores y alumnos. 


\begin{abstract}
In undertaking a hermeneutic-philosophical discourse, centered on the notion of Bildung or human formation, it emerges as an epistemic objective to provide meaningful explanations in the field of the Sciences of the Spirit. In this sense, HansGeorg Gadamer has had a fruitful philosophical innovation with repercussions both in the understanding of man and in ethics and politics. The investigation that we will make about his contributions to the Bildung is divided into two lines of questions. In the theoretical field: Is it true that Gadamer gives us an original version of the Bildung that can be said to exceed those conceived by the philosophers of the German tradition? Is its universality such that it can be applied to other realities outside the "Heritage of Europe"? In the field of application: Does your version of the Bildung have any significant ethical or political relevance or incidence in today's society? We will answer these questions by showing, at first, the semantic history of the word Bildung using as references the research carried out by Reinhart Koselleck and the theories of Johann Herder and Wilhelm von Humboldt. Later, we will analyze the Hegelian perspective of formation as a process centered on the category of "ascent to universality". Both parties seek to establish the fundamental theoretical antecedents from where Gadamer was nourished for the elaboration of his hermeneutics. And, finally, we will expose those revealing theoretical-practical contributions that Gadamer incorporated into the spectrum of Bildung from the humanistic tradition.
\end{abstract}

Keywords: Gadamer, Hegel, Bildung, humanistic tradition, hermeneutics, rise to universality, ethical-political scope. 


\section{RESUMEN}

Al emprender un discurso hermenéutico-filosófico, centrado en la noción de Bildung o formación humana, emerge como objetivo epistémico proporcionar explicaciones significativas en el ámbito de las Ciencias del Espíritu. En este sentido, Hans-Georg Gadamer ha tenido una fecunda innovación filosófica con repercusión tanto en la comprensión del hombre como en la ética y la política. La indagación que haremos sobre sus aportes acerca de la Bildung se bifurca en dos derroteros de preguntas. En el terreno teórico: ¿Es cierto que Gadamer nos da una versión original de la Bildung que se puede decir que supera las concebidas por los filósofos de la tradición alemana? ¿Su universalidad es tal que pueda aplicarse a otras realidades fuera de la «Herencia de Europa»? En el ámbito de la aplicación: ¿Su versión de la Bildung tiene alguna pertinencia o incidencia ética o política significativa en la sociedad actual? Responderemos a estas interrogantes mostrando, en un primer momento, el recorrido histórico-semántico del vocablo Bildung utilizando como referencias las investigaciones realizadas por Reinhart Koselleck y las teorías de Johann Herder y Wilhelm von Humboldt. Posteriormente, analizaremos la perspectiva hegeliana de la formación como un proceso centrado en la categoría de «ascenso a la universalidad». Ambas partes persiguen establecer los antecedentes teóricos fundamentales desde donde Gadamer se nutrió para la elaboración de su hermenéutica. Y, finalmente, expondremos aquellas contribuciones teórico-prácticas reveladoras que Gadamer incorporó en el espectro de la Bildung a partir de la tradición humanística.

Palabras clave: Gadamer, Hegel, Bildung, tradición humanística, hermenéutica, ascenso a la universalidad, alcance ético-político. 


\section{ÍNDICE}

Pág.

Introducción

\section{CAPÍTULO I}

El concepto Bildung en la tradición humanística alemana

1.1. Antecedentes histórico-semánticos y escollos de la noción Bildung ...

1.2. Johann G. Herder: la Bildung como «ascenso a la humanidad»

1.3. La Bildung herderiana: problemas, trazas y retos

1.4. Wilhelm von Humboldt: el lenguaje en la relación mundo-hombre-

Bildung

\section{CAPÍTULO II}

La Bildung en la filosofía de G.W.F. Hegel

2.1. El hombre en su singularidad

2.2. La formación como «ascenso a la universalidad»

2.3. Variaciones: la Bildung entre lo cultural, lo histórico y la vida en común

\section{CAPÍTULO III}

La Bildung en la hermenéutica de Gadamer: originalidad y repercusión social

3.1. Fuentes de la visión gadameriana de formación

3.2. La tradición humanística: más allá de la voluntad metodológica

3.3. Alcance político de la Bildung en el complejo mundo actual

Conclusiones 


\section{INTRODUCCIÓN}

El cómo ha de formarse a los individuos dentro de una sociedad ha sido, desde la Paideia griega, una de las constantes y esenciales preocupaciones de la cultura occidental. De hecho, sobre el alcance del concepto de formación y sus equivalentes cultura, educación, instrucción, entre otros- se han escrito una inmensa cantidad de libros y artículos. Se han realizado encuentros reflexivos de toda índole para comprender y poner a tono la cuestión formativa en los heterogéneos contextos culturales. Su importancia proviene de esas posibilidades sociales que se encuentran comprometidas con los anhelos humanos más significativos.

Diferentes áreas del saber humano como la sociología, la educación, la antropología, la política, entre otras se han dado a la tarea espinosa de establecer los parámetros, principios o valores desde los cuales se puedan orientar la vida individual y colectiva. La filosofía ha sido uno de esos saberes que ha contribuido axialmente en el establecimiento de los criterios esenciales para configurar el propósito formativo. Así, filósofos como Platón, Aristóteles, J.J. Rousseau, J. Locke, I. Kant, G.W.F. Hegel, entre otros, han dejado teorías educativas o pedagógicas de mucha trascendencia para la humanidad.

En cualquier contexto de investigación se hace imperioso demarcar y comprender el valor que puedan tener los conceptos esenciales de los autores que se van a estudiar. En nuestro caso nos ocuparemos de revisar, cómo se plantea y cómo se constituye el vocablo Bildung. En este tiempo (post)moderno y esquivo Hans- 
Georg Gadamer ha resignificado y actualizado, en su obra principal Verdad y Método, el concepto de formación (Bildung) enraizado en la tradición humanística y clave de su hermenéutica filosófica encaminada a aportar tentativas de entendimiento o diálogo (Gespräch), desde una ontología del lenguaje. Así, la experiencia humana se impulsa hacia una apertura a la alteridad, poniendo énfasis en acoger al otro en tanto otro a partir del cultivo de la dialogicidad. Un enfoque que tiene consecuencias ético-políticas profundas dentro de la sociedad.

El carácter original que tiene la Bildung en Gadamer será, precisamente, el objetivo central del presente estudio. Mostraremos que su concepción formativa constituye, a la luz de los aportes de las Ciencias del Espíritu, los aspectos esenciales de la tradición alemana: ascenso a la humanidad (Herder), lenguaje, sensibilidad y dimensión dialógica (Humboldt), el sentido de tacto psicológico (Helmholtz) y las obligaciones particulares y universales de los individuos (Hegel), entre otros. Todo esto para responder de manera incisiva y sugerente a las interrogantes y retos de la sociedad actual: el dominio (Beherrschung) de la ciencia, la incursión de los expertos en todos los ámbitos de la vida y la necesidad de comprensión del mundo dentro de una diversidad de lenguas. Así, el rasgo fundamental de su análisis se encuentra en la apertura a la tradición que corresponde al Otro como alteridad y aceptar todo lo que venga de él en condición de posibilidad. En realidad, de lo que se trata es de dejar valer la tradición en sus propias presunciones para que podamos de algún modo, apoyar nuestros supuestos básicos, es decir, nuestra forma de ver el mundo. 
Para exponer y analizar los planteamientos gadamerianos hemos dividido el trabajo de investigación en tres capítulos, metodológicamente estructurados. En el primero abordamos la palabra Bildung. Nos hemos basado, fundamentalmente, en la obra Historia de conceptos de Koselleck. En este sentido, el autor nos presenta todos los matices semánticos que Bildung ha tenido, a través del tiempo, en algunas figuras alemanas representativas como: Goethe, Wieland, Mendelssohn, Herder, Humboldt; sin embargo, su interés primordial es, como veremos, analizar la formación como autodeterminación personal y como forma de vida.

Para solventar la dificultad y a su vez reforzar la semántica de la Bildung utilizaremos algunos artículos especializados del ámbito filosófico que nos amplíen la comprensión de este complejo y diacrónico concepto en aquellos aspectos no analizados por Koselleck. También complementaremos este apartado con las perspectivas que tienen tanto Herder como Humboldt sobre las implicaciones éticopolíticas de la Bildung. Del primer autor exploraremos la categoría de «ascenso a la humanidad» en el que se resumen todas las facultades potenciales del hombre dentro de un sistema universal armónico; el trayecto que recorre este filósofo en su texto Idea es ir formando al ser humano hacía una educación para la humanidad. En cuanto al segundo, analizaremos su distinción entre cultura como acumulación de conocimiento, producción artística o científica y formación como fuerza vital de comprender y obrar, y repararemos en cómo defiende afanosamente el origen humano del lenguaje. De ambos estudiaremos sus concepciones en torno al lenguaje en vista de que lo relacionaron con una visión del mundo y con un proceso formativo-cultural. 
La inclusión de estos dos filósofos se debe a que consideramos que son referencias fundamentales para aproximarse al giro lingüístico y práctico de la hermenéutica gadameriana.

En el segundo capítulo estudiaremos la Bildung en el pensamiento de Hegel. Lo analizaremos tal como el autor la desarrolla en varias de sus obras pero, fundamentalmente, en su Fenomenología del Espíritu y en sus Escritos pedagógicos. Este filósofo alemán emplea este concepto clave con los alcances de cultura, formación y educación, dependiendo del ámbito argumentativo e histórico en los que lo utiliza. No obstante, dos son los significados que quisiéramos resaltar: teórico y práctico. Un primer registro revelador tiene que ver con la formación teórica y se refiere a la variedad y especificidad de los conocimientos; el otro, a la universalidad de los puntos de vista frente a las cosas y a la autonomía de sentido de los objetos ${ }^{1}$.

Un segundo significado del término, con acento en la práctica, es la de «formarse a sí mismo» (Selbsttraining) que corresponde al plano universal. Tiene por base la «conservación de sí mismo» que incumbe a la individualidad. Para Hegel, el deber primordial de cualquier sujeto es velar por su vida o cubrir sus necesidades naturales básicas. En este aspecto está determinado por su estado de naturaleza, es decir, se rige por sus instintos lo cual lo hace contingente e irracional. Pero como el compromiso consigo mismo no termina en esta obligación, el problema que surge es ¿cómo hace para salir de su inmediatez? O más bien ¿por qué ha de superar esta condición natural? Hegel responderá que el individuo, como ser racional, tiene otra

Cf., Hegel, G.W.F., Escritos Pedagógicos, Trad. Arsenio Ginzo, México, Fondo de Cultura Económica, 1998, pp. 183-188. 
exigencia igualmente imprescindible: formarse. A través del proceso formativo, puede "contemplar las cosas desde la posición de otro", lograr ser prudente o moderar su proceder e insertarse en una cultura donde se realiza en tanto ser espiritual, Hegel lo plantea en estos términos “considerando en su formación cultural al individuo universal, al espíritu autoconsciente de sí mismo"3. Y así elevarse a la universalidad. Para el filósofo alemán, ascender a lo universal es un recorrido que la conciencia realiza a través de las distintas figuras del espíritu comenzando por la dialéctica del espíritu subjetivo, la certeza sensible, percepción, entendimiento, autoconciencia, amo-esclavo, entre otras; se trata de un movimiento dialéctico (Dialektische) o automovimiento donde se logra la formación del concepto (Begriff).

Lo que nos interesa exponer es cómo mediante ese automovimiento el espíritu se va formando. Ahora bien, para alcanzar una mejor comprensión consideramos hacer el recorrido tal como Hegel recomienda. Haremos el itinerario en su Fenomenología del Espíritu a partir de la certeza sensible para analizar desde la inmediatez del ser su arribo formativo hasta la autoconciencia y vida, y finalmente llegar al espíritu objetivo considerado como la conciencia colectiva o universal.

Estos dos capítulos sirven de antecedentes imprescindibles para tener una comprensión más próxima a la configuración gadameriana de Bildung. El primero nos permite señalar las fuentes en las que abrevó Gadamer para desplegar sus ideas relacionadas con la ontología del lenguaje, la dinámica dialógica (pregunta-respuesta)

2 Koselleck, R. y Gadamer, H-G., Historia y hermenéutica, Trad. Faustino Oncina, Barcelona, Ediciones Paidós Ibérica, 2006, p. 125.

3 Hegel, G.W.F., Fenomenología del Espíritu, $4^{\mathrm{a}}$ ed. Trad. Wenceslao Roces y Ricardo Guerra, México, Fondo de Cultura Económica, 2006, p. 21. 
y la apertura a la humanidad (fusión de horizontes). El dedicado a Hegel -uno de los tres grandes interlocutores (Partners des Gesprächs) ${ }^{4}$ que Gadamer reconoció-, nos posibilita indicar su influencia en aspectos tan importantes como el sentido dialécticotransformador del proceso formativo y un concepto de subjetividad que es a la vez «trascendente» en tanto universal e «inmanente» por estar inmerso en una historia efectual (tradición).

Gadamer logra desarrollar los conceptos básicos del humanismo como formación, sensus communis, la capacidad de juicio y el gusto, sustentados en la tradición histórica que por cierto jugará un papel fundamental en Verdad y Método. En el tercer capítulo analizaremos la Bildung en Gadamer. Lo haremos en dos momentos. En el primero veremos la forma cómo Gadamer reestructuró de manera única todas las influencias recibidas, que ya esbozamos, junto a las de Giambattista Vico e Immanuel Kant y que designó «tradición humanística». Mostraremos que la novedad u originalidad en este caso radica en que la Bildung o ideal de formación no es analizada aisladamente sino que es vista como un proceso complejo en el que los individuos desarrollan varias capacidades. Una es el juicio: que tiene un sentido ético y que carece de reglas fijas por lo que se encuentra en un estado de permanente perplejidad; no puede enseñarse sino que debe vivirse o ser ejercida permanentemente y en este sentido se asemeja a una experiencia. Dentro de su esfera de acción se encuentra el gusto que, para Gadamer, es tanto un fenómeno social como un modo específico de conocer.

4 Los otros dos son Platón y Kant. Evidentemente habría que mencionar, en esta misma línea a Aristóteles, Heidegger y Dilthey. 
El gusto es la capacidad de discernimiento espiritual que no se limita a ser una vana preferencia, cuestión privada o una moda pasajera sino que tiene una pretensión de validez. Su opuesto es la «falta de tacto». Por otro lado, presenta como preámbulo, la cuestión del baremo para introducirse luego en la idea de formación "pero a medida que los métodos de la ciencia se extienden a todo lo existente resulta más dudoso que los presupuestos de la ciencia permitan plantear la cuestión de la verdad en todo su alcance" ${ }^{, 5}$. En todo caso, la verdad no es sólo algo esencialmente relativo al método. No necesariamente las ciencias positivas son las únicas que pueden dar como verdadero un resultado propio de la rigurosidad de esa ciencia, también y esto es lo interesante que plantea Gadamer, existen otras vías para llegar a la verdad que se dan en las ciencias del espíritu, cosa que veremos con detalle en el tercer capítulo.

La tercera capacidad que se despliega en este proceso formativo es el sentido común (sensus communis), que expresa las convicciones fundamentales compartidas; se trata de una generalidad concreta y decisiva de lo bueno y lo malo que orienta la voluntad humana y se alimenta en el cultivo de la elocuencia moral y la prudencia (phronēsis). Todas estas potencialidades humanas las enmarca Gadamer en el nuevo viraje de las «ciencias del espíritu» en el que se busca trascender tanto la cuestión del método como la verdad como correspondencia (adaequatio intellectus ad rem).

En un segundo momento trataremos de fundamentar que la teoría gadameriana de formación es pertinente, factible y necesaria para la época actual. Gadamer identificó unos retos o problemas a los que trató de dar respuesta desde su

5 Gadamer, H-G., Verdad y Método II, Trad. Manuel Olasagasti, Salamanca, Ediciones Sígueme, 2006, p. 52. 
hermenéutica dialógica. He aquí unos ejemplos. Frente a los escollos que trae la diversidad de las culturas propuso su teoría de la fusión de horizontes sustentada en una ontología del lenguaje; ante la irrupción de los expertos propuso un retomar el concepto de autoridad basada en la experiencia y la moral; como una decisión fundamentada en la razón social.

Se podría pensar que sus respuestas no representan soluciones políticas contundentes sino que más bien encarnan salidas éticas. Nosotros pensamos que este carácter formativo-ético, inspiración de nuestra investigación, es lo más original de la filosofía gadameriana. En su ideal de formación se plasma un ser humano tolerante, dialógico, prudente, abierto a la diferencia, solidario, que sabe escuchar. Todas capacidades imprescindibles en los tiempos que corren signados por el escepticismo, la apatía, la exclusión y el abuso del poder. Se podría decir que la ética es la política por cuanto ella lleva en su seno siempre la negación a todo tipo de vejamen de la condición humana pero, a la vez, la afirmación en las posibilidades infinitas de construcción de sociedades más libres y justas.

La investigación que llevaremos adelante es esencialmente de carácter teórico y, por consiguiente, los procedimientos metodológicos se harán de acuerdo con una investigación documental. Utilizaremos los textos filosóficos fundamentales de Gadamer y Hegel que den cuenta de la Bildung.

En la primera sección de la investigación examinaremos el término Bildung utilizando el método histórico-semántico. Nos basaremos, fundamentalmente, en el 
texto Historias de conceptos de Reinhart Koselleck $^{6}$ en donde se emprende un trabajo pragmático, histórico, etimológico y cultural de los conceptos y cuya finalidad es articular el lenguaje con la vida político-social. Según este acucioso autor, la palabra alemana Bildung en su larga trayectoria de uso, ha tenido dificultades para ser traducida a otros idiomas. De hecho, sinónimos como instrucción, educación, cultura, formación y otros afines se han quedado cortos ya que no dan cuenta del significado profundo del término en cuestión. En este sentido, Koselleck hará un recorrido diacrónico (continuidades y rupturas) por todas aquellas acepciones que el vocablo ha tenido en su doble función de indicador y factor de proceso social. Esto lo hará tomando como referencia figuras representativas en los diferentes ámbitos de la cultura alemana. En su incursión enfatizará la Bildung en los significados de «forma de vida»y «autodeterminación personal», que son dos enfoques centrales en la hermenéutica gadameriana.

En el capítulo donde analizaremos la formación en Hegel nos valdremos del método hermenéutico, en su sentido amplio de interpretación. Se persigue, esencialmente, comprender o desentrañar los sentidos de las complejas categorías que subyacen en los textos hegelianos que serán objeto de estudio. Trataremos de hacer una especie de actualización semántica lo más ceñida a cada término original y una explicitación articulada de los argumentos del filósofo. La exégesis irá acompañada de una visión crítica cuando sea imprescindible para una contextualización del alcance de la concepción hegeliana de la Bildung.

6 Koselleck, R., Historias de conceptos. Estudios sobre semántica y pragmática del lenguaje político y social, Madrid, Editorial Trotta, 2012, pp. 49-93. 
En cuanto al apartado dedicado a Gadamer acudiremos igualmente al método hermenéutico para indagar Bildung en la perspectiva humanista del autor que, como fenómeno filosófico-cultural que a partir de finales del siglo XVII hasta inicios del siglo XIX, reivindica el sensus communis, la capacidad de juicio, el gusto y a filósofos como Vico, Herder, Humboldt y Hegel.

También utilizaremos el método comparativo por cuanto nos proponemos establecer tanto las discrepancias como las afinidades que existen a partir de los antecedentes históricos y hegelianos de la Bildung con respecto a la noción que tiene Gadamer. La finalidad no es otra que exponer las potencialidades y los puntos novedosos del autor y así tener una comprensión más precisa de su hermenéutica filosófica. Al mismo tiempo presentar la "aplicación" ético-política que tiene esta reivindicación de la Bildung con respecto a tres problemas que el propio Gadamer planteó en muchas de sus obras: el poder de manipulación de las ciencias a través de la fabricación (herstellen), el deterioro de la razón social por proliferación de expertos y funcionarios y la «diversidad de las lenguas y la comprensión del mundo». 


\section{CAPÍTULO I}

\section{EL CONCEPTO BILDUNG EN LA TRADICIÓN HUMANÍSTICA}

\section{ALEMANA}

\subsection{Antecedentes histórico-semánticos y escollos de la noción Bildung}

Empecemos por abordar el término Bildung a partir del análisis históricosemántico realizado por Reinhart Koselleck ${ }^{7}$ que, en su texto Historia de conceptos, emprende un trabajo pragmático, histórico, etimológico y cultural cuya finalidad es articular el lenguaje con la vida político-social. Este filósofo e historiador considera que la palabra alemana Bildung, en su larga y proteica trayectoria de uso, ha tenido dificultades para ser traducida a otros idiomas. De hecho, afirma que la "Bildung es uno de esos conceptos específicamente alemanes cuyo contenido y extensión semántica no coinciden con los conceptos occidentales"8 en uso. Los sinónimos sugeridos no dan cuenta del significado profundo del concepto en cuestión. Tal y como Rebekka Horlacher nos dice: Bildung "es prácticamente intraducible a cualquier otro idioma: $\mathrm{Ni}$ «educación», ni «instrucción», ni «capacitación», ni «formación», ni «crianza» se acercan siquiera a la ambición cultural en la semántica de Bildung"9.

7 Reinhart Koselleck (1923-2006), importante historiador alemán y un gran divulgador y analista del pensamiento gadameriano. Su 'estilo metodológico' de analizar los conceptos desde diferentes ángulos teóricos, se ha convertido en referencia obligatoria para la comprensión de aquellos problemas éticos, políticos o sociales que en determinadas épocas fueron trascendentales.

$8 \quad$ Koselleck, R., Historias de conceptos..., op. cit., p. 54.

9 Horlacher, R., "¿Qué es Bildung? El eterno atractivo de un concepto difuso en la teoría de la educación alemana", en Revista de Investigación Educacional Latinoamericana, 51 (1), 2014, p. 36. Y podríamos agregar a la lista de esta autora estas categorías: presunción, religión, 
El vocablo instrucción (Anweisung) es un caso emblemático de una traducción fallida. Koselleck, al inicio de su texto, sostiene que es inapropiado sustituir Bildung por instrucción. El motivo es que esta acepción no es la única presente entre tantos significados posibles que le da la sociedad alemana a Bildung. Aunque, desde un contexto ajeno al espíritu alemán es utilizada como instrucción por su aproximación al actuar educativo o formativo.

Ahora bien, si tomamos la idea de instrucción como algo específico podríamos decir, en línea con el historiador, que con ella "se trataba la profesionalización que reguló las carreras académicas de las antiguas facultades y las de las nuevas ciencias naturales"10. Era imprescindible especializar e instruir a los individuos en determinadas áreas en aquellas corporaciones y asociaciones independientes de las universidades. Los dos procesos de formación técnica o utilitaria eran garantizados por el Estado. De este modo, la Bildung se configuró en "instrucción de una forma que posibilitó la abstención de privilegios de clase neoestamentales"11. En la situación actual la profesionalización se ha horizontalizado o ha permeado cada vez más en los miembros de una sociedad aunque no necesariamente en función del progreso humano sino en respuesta a las exigencias del mercado.

Sin soslayar las dificultades semánticas, Koselleck como historiador de las ideas hará un recorrido diacrónico, en sus continuidades y rupturas, por todas aquellas

ideología, «ninguna tendencia filosófica específica», «ninguna visión estética», «ninguna tendencia literaria o institución». Es imprescindible resaltar que la Bildung ha tenido una influencia capital no sólo en el ambiente educativo dentro de las fronteras alemanas sino que también ha logrado que sus principios fundamentales influyeran en otras culturas.

10 Koselleck, R., Historias de conceptos..., op. cit., p. 51.

11 Ibídem. 
acepciones que la Bildung ha tenido en su doble función de indicador y factor decisivo de un proceso social. Lo emprenderá tomando como referencia figuras representativas en los diferentes ámbitos de la cultura alemana. En su incursión enfatizará la Bildung en los significados de «forma de vida» y «autodeterminación personal», lo que lo ha llevado a plantear que por "mucho que el culto al genio ayudase al nacimiento del concepto Bildung y por mucho que el descubrimiento de la personalidad también contribuyese a ello, el concepto Bildung se refiere a una persona concreta" ${ }^{\prime 2}$. Quiere enfatizar con esto que a todos los seres humanos, orientados por personas e instituciones adecuadas, les corresponde la tarea de formarse y no solamente a los natural o contextualmente privilegiados.

Se ha de considerar, nos dirá Koselleck, que la Bildung que debe nutrir, sustentar y orientar a la sociedad alemana, según los históricamente influyentes pensadores, educadores o historiadores, escapa a la pretensión semántica de determinar un significado unívoco que la aleja de su verdadera razón de ser social. Por eso, se dieron a la tarea de buscar denodadamente y de un modo sistemático investigar "los ámbitos vitales en los que se cultivaba el patrimonio cultural [Bildungsgut] y el conocimiento de la cultura [Bildungswissen]"13. Prestaron atención, de manera formal, a la filosofía, a la teología, a la religión, de igual forma consideraron a las ciencias del espíritu y las naturales, así como a la música, a las artes, la literatura y la pedagogía, para, finalmente, tener un significado de Bildung acorde a las pretensiones formativas de Alemania.

\footnotetext{
Ibíd., p. 60.
}

Ibid., p. 51. 
Evidentemente, los matices semánticos de Bildung, que veremos posteriormente, se encuentran en sintonía con las iniciativas y formas por «ilustrar», en todos los órdenes, que han caracterizado a la sociedad alemana en su sugestivo, dilatado y, en algunos momentos, tortuoso trayecto histórico. Además, se debe advertir que las distintas acepciones de Bildung, que se fueron fraguando lentamente a través del tiempo, se configuraron, de una manera particular, en el espíritu alemán (Deutscher Geist).

Después de este marco general, las preguntas de rigor que surgen son: ¿Qué es realmente la Bildung?, ¿cómo la podemos determinar tomando en consideración su complejidad y su posible significado? Además, ¿qué pertinencia tiene para nuestra indagación comprender dicho concepto? En todo caso, debemos partir de una incursión etimológica y, de ser posible una definición nominal de Bildung que nos permita abordar sus densas acepciones y al mismo tiempo sus implicaciones éticopolíticas para una sociedad.

El vocablo Bildung, desde el punto de vista etimológico, viene de Bild ${ }^{14}$ y está enmarcado dentro de las acepciones de 'imagen', 'cuadro' y también se podría asumir como la 'imitación de una imagen' ${ }^{15}$. Esta raíz a su vez se traduce en un sentido activo en Bilden: 'crear' 'dar formar', 'que se aprende' ${ }^{16} \mathrm{y}$, finalmente, llega a Bildung en su significado de 'formación', que es la traducción que se ha impuesto en

14 Gadamer, H-G., Verdad y Método I, $3^{\text {a }}$ ed., Trad. Ana Agud Aparicio y Rafael de Agapito, Salamanca, Ediciones Sígueme, 2007, p. 40.

15 Cf. Sianes, A., "Bildung": Concepto, evolución e influjo en la pedagogía occidental desde una perspectiva histórica y actual, Revista española de educación comparada, $\mathrm{N}^{\circ} 30$, Julio - diciembre 2017, pp. $99-111$.

16 Koselleck, R., Historias de conceptos..., op. cit., p. 55. 
el plano internacional. Lo más importante que queremos resaltar, en este breve recorrido, es que la palabra "Bildung se da en íntima relación con otras expresiones como las de Geist (espíritu) y Freiheit (libertad)"17. Estos tres términos Bildung, Geist y Freiheit constituyen los cimientos sobre los cuales descansa una pedagogía que atiende a la plenitud de lo humano en el hombre. Aparte de resaltar cada una de estas distintas raíces etimológicas, el examen de ellas servirá para establecer las posibles directrices, en cuanto a sus fundamentos, que tomarán las Ciencias del espíritu (Geisteswissenschaften) a través Gadamer, tal y como lo ejemplificaremos en el tercer capítulo.

Como podemos observar, las esferas en las que la acción humana puede desplegar su libertad dentro de la Bildung son muy amplias: imagen (imitacióninfinidad de modelos), desarrollo del espíritu (actualización de todas las potencialidades). La idea transversal presentada por el historiador alemán Koselleck en su investigación no es más que esto: el cultivo de la forma heterogénea de ser, que permite a una sociedad (alemana) establecer una base que le da sentido a su idiosincrasia en cada segmento y expresión de la vida.

Detrás de la idea de Bildung se encuentra un importante grupo pujante que está enmarcado en la llamada burguesía ${ }^{18}$, que, sin lugar a dudas, logra aclarar el problema socio-histórico que permitió crear una estrecha relación entre lo económico

17 Vilanou, C., "Formación, cultura y hermenéutica", en Revista de Educación, № 328, Barcelona, 2002, p. 206.

18 El surgimiento de la burguesía fue tan importante que hasta sus críticos más encarnizados como Karl Marx y Friedrich Engels reconocen que esta clase "ha desempeñado un papel altamente revolucionario en la historia" (Marx, K. y Engels, F., Manifiesto comunista, Trad. Pedro Ribas, Madrid, Alianza Editorial, 2007, p. 44). 
y lo social. Es precisamente la participación de la burguesía y su hacerse de la Bildung donde logra un predominio social, un poder que le permite desenvolverse en el desarrollo económico y cultural. Koselleck nos explica que "en el campo conceptual occidental de civilisation hay un antiguo contenido europeo que procede de la societas civilis de la sociedad burguesa, que a partir del siglo XVIII adquiere una fuerza política renovada" ${ }^{19}$. Esta forma de abordar la Bildung con sentido hegemónico se expresa en una dominación como validez. Esto le permitió a la burguesía disfrutar de un estatus social privilegiado en la sociedad alemana y en los otros contextos en donde se desarrolló, como el caso de Inglaterra.

Cuando la política, lo social, lo cultural y lo moral confluyen en la idea de Bildung es manifiestamente fruto de la Ilustración (Aufklärung). Decimos esto a sabiendas de que en otras épocas estos mismos aspectos de la praxis humana han estado presentes como en el caso de la Paideia griega (desde otros criterios). El punto de partida tuvo lugar precisamente en el siglo de las luces, donde tuvo mayor relevancia. Así, el siglo XVIII "se ha denominado la época de la Ilustración y el siglo XIX puede denominarse el siglo de la Bildung, ambos conceptos son más que simples denominaciones históricas” ${ }^{20}$. Los cambios constantes y la permanente innovación han permitido que la Bildung logre agregar a su haber distintas formas de configurar la sociedad por ser un concepto "más moderno, más abierto a experiencias

Koselleck, R., Historias de conceptos..., op. cit., p. 53. Ibíd., p. 59. 
sorprendentes y a nuevos puntos de vista, más «interesante» y libre, sobre todo debido a la amplitud de su definición, rica en facetas"21.

Tanto fue la pluralidad de vidas que irrumpió en la Ilustración que nos atrevemos a decir que se trató de un auténtico avance humano, un "tomar el control de la propia Ilustración"22 con la Bildung como lema. Momento por cierto importante de la secularización ${ }^{23}$, pues fue la Ilustración quien proporcionó las pautas para que sus propios ilustrados tomaran el control, esto indudablemente causó malestar en algunos y alegría en otros, la apertura al conocimiento, al saber, tuvo una gran defensa por parte de la sociedad de ilustrados y científicos y una rotunda resistencia y rechazo por parte de algunos protestantes como de católicos y conservadores. Gracias a la Ilustración se logró una apertura que permitió un sustancial avance en lo social, político, artístico y científico; la razón tomó el control sustituyendo de alguna manera prejuicios dogmáticos, religiosos existentes.

Koselleck ha aclarado que la ilustración inicialmente "se concibió, desde la perspectiva de la historia de la filosofía, como un periodo a clasificar diacrónicamente con un programa que, sin embargo, pretendía ser atemporal y científico" ${ }^{\text {,2 }}$. Es, precisamente, este carácter universal de su programa que ha servido de base para

\footnotetext{
Ibídem.

Ibídem.

En sentido amplio, la secularización deriva de 'secular' que viene del latín saeculum es decir 'siglo'. Con estas pautas podemos señalar que se ha logrado superar la edad de la fe y dar paso a la razón, es la evanescencia de las antiguas sacralidades. Con el surgir de la ilustración Aufklärung, de la ciencia, de la racionalidad se logró un gigantesco paso para la humanidad dejando a un lado la superstición paralizante.

24 Koselleck, R., Historias de conceptos..., op. cit., p. 51.
} 
clasificar a las sociedades y a las diferentes corrientes: filosófica, educativa, literaria, entre otras.

Ahora bien, hablemos de la Bildung en la esfera cultural. Al disertar sobre el alcance de la formación en los procesos culturales no podemos dejar de insistir en los aportes del pueblo alemán al respecto. Como los alemanes se percataron de las inmensas posibilidades que se pueden lograr a través de la Bildung, la hicieron inmanente en todos los ámbitos del quehacer diario. Pero donde se ha reflejado más este apostar la formación colectiva ha sido en sus logros y éxitos filosóficos, literarios, científicos, musicales, entre otros que han repercutido, significativamente en el plano internacional. La pregunta que se podría hacer es: ¿Cómo alcanzar una bilateralidad dialéctica Bildung-cultura social? en una sociedad como la nuestra signada por el individualismo exacerbado e insensibilidad social, por el culto al dios Mamón (dinero) que todo lo resuelve y por el desespero por consumir o triunfar a toda costa.

En el plano social, la tesis que sostiene Koselleck es que la Bildung "al igual que ilustración o religión- no es primordialmente un concepto social" ${ }^{\text {25 }}$. En primer lugar, hay que partir del hecho de ¿a qué se debe esta acotación del autor? Parte de la premisa de que podría tratarse de un equívoco pues no sería difícil pensar que la Bildung se identificara con lo que se entendía socialmente por una persona cultivada perteneciente al estamento burgués, esto es, los artesanos, los comerciantes, el clérigo o un trabajador común y corriente. Pensamos que la acepción que le da el historiador

25 Ibídem. 
a lo social es que es algo puntual o contextual dentro de la magnitud de la Bildung porque aunque ésta se refiera "a un comportamiento activo y define ámbitos de actividad social" ${ }^{, 26}$, no implica que se reduzca a un acto o término sociológicos. Lo que sí envuelve es que es "una forma particular de comportamiento y de conocimiento que se potencia a sí misma y que para poder desarrollarse depende de unas condiciones económicas y políticas"27.

La identificación Bildung-concepto social es un problema que sigue vigente con mayor fuerza en esta era tecnológica y las consecuencias son también más nefastas. Se forma pensando en los requerimientos de la sociedad. Muy bien, el propósito socio-político es muy loable pero el problema radica en saber ¿quiénes son los que establecen los requerimientos y con qué fines? Las luchas educativas han sido las respuestas a estas dos preguntas.

Si pasamos al ámbito de lo histórico, nos encontramos con que todo proceso formativo es a la vez efecto y superación del pasado. La Bildung es un concepto histórico que hace historia. Tiene cierta razón Werner Jaeger cuando nos dice en su "Paideia" que la: "palabra alemana Bildung (formación, configuración) designa del modo más intuitivo la esencia de la educación en el sentido griego y platónico"28. La conciencia histórica ha sido uno de los grandes aportes de la cultura alemana. Historiadores como Leopold von Ranke, Heinrich Rickert, Wilhelm Windelband, Wilhelm Dilthey, sólo para mencionar algunos, han mostrado que para la México, Fondo de Cultura Económica, 2001, p. 11. 
comprensión de cualquier asunto humano de trascendencia es imprescindible el contexto histórico. La historia surte experiencias, valores y parámetros éticos que como un magma alimenta a las generaciones futuras. Estas ideas de fondo las radicalizó Gadamer, en su hermenéutica filosófica, a través del concepto de tradición, como veremos más adelante. Incluso, dio unas conferencias sobre la experiencia histórica, en las que sostiene que la "aparición de una toma de conciencia histórica es verdaderamente la revolución más importante de las que hemos experimentado tras la llegada de la época moderna"29.

La pertinencia de la conciencia histórica nos traslada a abordar la Bildung desde la autoformación o autodeterminación (Selbstbestimmung).Tanto el desarrollo de las cualidades naturales como la asimilación histórica son imprescindibles para la formación. La autoformación se da cuando cada persona concreta trabaja, con disciplina $(Z u c h t)^{30}$, su naturaleza o forma de ser en un contexto específico, entendiendo éste como la parte inmanente de su idiosincrasia. Esto quiere decir que se lleva a cabo desde la sociabilidad porque "tanto la propia de las personas como la específicamente grupal, es un elemento constitutivo de la Bildung"31 . No se comparte en el sentido social, sino que más bien se debe mantener una constante individualidad o independencia en ese estar en contacto con el otro.

Un elemento primordial de autodeterminación, aparte del uso de los diarios escritos, es la transferencia de la experiencia autorreflexiva "de Bildung a otros

29 Gadamer, H-G., El problema de la conciencia histórica, Trad. Agustín Domingo Moratalla, Madrid, Editorial Tecnos, 2007, p. 41.

Cf., Koselleck, R., Historias de conceptos..., op. cit., p. 61.

Ibídem. 
autores: al pueblo, la nación, la comunidad, la sociedad, o la infancia, la juventud, y al resto de las edades, o a una clase o Estado, y finalmente a la naturaleza y a la historia" ${ }^{32}$. Este tipo de acción muestra que una persona se ha cultivado a tal nivel que propicia un entorno estimulante y pertinente para que otros se animen a actuar en su propia formación. Claro está todo en función de un ascenso de toda la humanidad.

Otro aspecto que contribuye con la Bildung es el intercambio epistolar que formaba parte de la cultura germana de finales del siglo XVII y todo el siglo XVIII. La correspondencia siempre fue un factor vital entre los individuos y entre los pueblos. Lo que se debía comunicar variaba de temas y de importancia. Entre los pensadores, científicos, literatos, el intercambio contribuyó para la difusión de nuevas ideas, de anuncios de incipientes proyectos científicos, de promesas de próximas novelas o cuentos. Pero también sirvió para la comunicación de pesares, esperanzas y apoyo moral. Tenemos el caso representativo de las epístolas ${ }^{33}$ que Séneca dirigió a Lucilio. En los momentos actuales se ha reavivado con el e-mail pero no sabemos si la producción de peso, a mediano y largo plazo, va a ser tan enriquecedora como en otros tiempos.

Dentro del arte epistolar desarrollado se hallan las multifacéticas autobiografías escritas que no sólo son la "continuación de los diarios, sino también de un arte epistolar muy desarrollado",34. Al igual que las cartas pueden "ser tan simples en

Ibíd., p. 60.

Cf., Séneca, Epístolas morales a Lucilio, Vols. I-II, Trad. Ismael Roca Meliá, Madrid, Editorial Gredos, 1986.

34 Koselleck, R., Historias de conceptos..., op. cit., pp. 62-63. 
algunos casos como magistrales en otros"35. La autobiografía tiene la función principal de transmitir una «experiencia de vida» que el autor de la misma considera válida para los otros. Aunque, no se puede perder de vista que en muchos casos prevalece, en este tipo de comunicación, el deseo de inmortalidad o de narcisismo solapado.

En esta misma línea de establecer vínculos formativos tenemos el «grupo de amigos» como la otra manera de transmitir el aprendizaje de la Bildung. Tiene que ver con personas que desean intercambiar puntos de vista, preferencias $\mathrm{u}$ otros intereses con la finalidad de cultivarse por medio de la socialización. Se potenció históricamente por el constante viajar hacia otras regiones, esto es, influyó el turismo "sediento de naturaleza y ávido de cultura, que se desplaza en coche y en avión, y la existencia de grupos aficionados a la música, los museos, los teatros ${ }^{\text {36 }}$. Todo generó grupos comunicativos. Este nivel de experiencia dialógica es crucial por cuanto se establece una relación intersubjetiva signada por la cercanía (proxemia), por el contacto con sus rituales sociales y espontáneos y, sobre todo, con una comunicación «cara a cara» más cerca de la transparencia moral.

Como hemos podido observar en todas estas pautas, la Bildung "es un metaconcepto, que constantemente incorpora en sí misma las condiciones empíricas que lo hacen posible" ${ }^{37}$. Dicho en otros términos, se caracteriza por el dinámico entrelazamiento semántico o conceptual, “constantemente renovado de los ámbitos

Ibíd., p. 63.

Ibídem.

Ibíd., p. 64. 
vitales concretos, ámbitos que se corresponden con los llamados bienes culturales y con el conocimientos cultural" ${ }^{\prime 38}$. Eso quiere decir, que abarca tanto lo religioso ${ }^{39}$, lo histórico, el problema del lenguaje, la música, el arte y la ciencia. Pero ninguna de ellas la puede especificar debido a su carácter ontológico de apertura. Lo que hemos expuesto ha sido porque consideramos que las muestras histórico-semánticas dan luces para una posible clarificación de la Bildung, sabiendo que apenas nos acercamos sutilmente a algunas de sus proteicas acepciones.

Estas reflexiones se reafirman cuando vemos que la Bildung no se reduce a ningún ámbito institucional "aun cuando sus frutos se hayan introducido en muchas instituciones: la familia, el colegio, la universidad, "los institutos, asociaciones, partidos, federaciones y uniones" ${ }^{40}$. El hecho es que la Bildung es también, como acertadamente señala Koselleck, un "metaconcepto político" ${ }^{41}$. Todos los estamentos mencionados como son esencialmente políticos le son compatibles e inherentes.

La Bildung podría tener otras funciones con un trasfondo político para enaltecer a la sociedad, pero desde adentro como "crear grupos agregados más complejos como, por ejemplo, el formado por los graduandos de institutos y universidades" 42 que permitirán hacer más funcional la Bildung y con una gran independencia de los distintos y posibles conceptos particulares que la formulan. Este punto político es digno de ser resaltado porque todavía se sigue viendo a la

\footnotetext{
Ibíd., p. 81.

Ibíd., pp. 81-85.

Ibíd., p. 68.

Ibídem.

Ibíd., p. 76.
} 
formación solamente enmarcada en la moral o la afirmación de valores. Perspectiva que ha estigmatizado muchas luchas reivindicativas en el plano educativo.

Dentro de esta perspectiva, tenemos otra idea que tendría una posible acepción de Bildung pero esta vez desde lo suprasocial. Es difícil definirla desde este ángulo porque ha prevalecido la idea de que son "los cultivados enmarcados en la aristocracia estamental subyacente (en la sociedad alemana) que determinaba y, sustancialmente diferenciaba entre la sociedad a los cultos de los incultos ${ }^{43}$. Tenemos, entonces, que formalmente la "Bildung es universal, pero en función de su contenido, elitista" 44 . Lo cual hace que tenga como punto de partida una elite que va abriéndose a los demás estamentos de la sociedad.

La profunda diferencia que ha existido y aún existe entre aquellos que dominan y los que son dominados, nos permite entender con mayor claridad esas características que separan a los cultos de los incultos. Lorenz Von Stein, según Koselleck, intenta denunciar esa profunda escisión que existe en la sociedad y sostiene que ha de ser mediante una profunda y ardua labor cultural donde se logre eliminar o reducir esa injusta separación. Plantea que "«única y exclusivamente» la labor cultural [bildende] de cada individuo consigue «enriquecer con bienes intelectuales a quien los recibe sin empobrecer al que los da»"45. Se logra así que la actuación de un sujeto, mediante su vida intelectual, erradique la insoportable oposición que existe bajo el dominio en vez de la cooperación. Menos mal que con el

\footnotetext{
Ibíd., p. 69.

Ibíd., p. 71.

Ibíd., p. 69.
} 
pasar del tiempo el "dominio de unos pocos espíritus sobresalientes -los cultos-

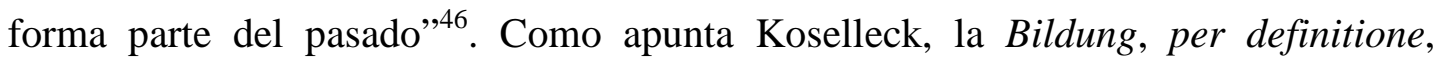
contradice cualquier "caracterización primordialmente social, por no hablar de una de tipo estamental o de clase" ${ }^{\prime 7}$.

Finalmente, nos queda por atender un asunto que creemos cardinal y que forma parte del tercer capítulo de nuestra investigación: la relación Bildung-ciencias naturales. Koselleck piensa que "se puede señalar que sin Bildung la autonomía lograda por las ciencias naturales, originalmente parte de la facultad de filosofía"48. Lo que el historiador nos quiere indicar es la escisión que se produjo 'artificialmente' en el ámbito académico por una necesidad metodológica o de complejidad temática que no da cuenta del verdadero sentido en que germinan y se entrecruzan los haberes culturales. La Bildung es un terreno de fuerza, a la vez reflexivo y comunicativo, que exige la unificación de todos los bienes de la vida y de las artes, así como de toda la magnitud del conocimiento. Se podría indicar que entre la formación y los avances acelerados y exitosos de las ciencias naturales, se engendra una espiral dialéctica que consiste en que el adelanto de una repercute en el perfeccionamiento de la otra y la síntesis histórica que originan las desborda a las dos. 


\subsection{Johann G. Herder: la Bildung como «ascenso a la humanidad»}

El pensamiento del filósofo Johann G. Herder (1744-1803) no fue tomado en cuenta con cierta mesura y suficiente veracidad en la esfera intelectual de su tiempo y aún en nuestros días son muy pocos los escritos de peso sobre su filosofía. Sin embargo, lo consideramos un autor fundamental por sus valiosos aportes en historia, lenguaje, literatura, religión e incluso se podría decir que también en la antropología $^{49}$. Ha permitido nutrir las ciencias humanas en la búsqueda de su ontología y enriquecido nuestra indagación sobre la hermenéutica de Gadamer.

En este apartado nos proponemos a analizar su concepción sobre la Bildung y nos hemos valido para esto del libro decimoquinto de una de sus obras substanciales: Ideas para una filosofía de la Historia de la Humanidad, publicada entre 1784 y $1791^{50}$. Igualmente, hemos revisado algunos trabajos críticos que hacen referencia a su asistemático itinerario intelectual con la finalidad de tener una visión panorámica sobre sus grandes intereses que, en opinión de G. Schmidt, confluyen hacia uno: el hombre $^{51}$. De hecho, Herder en el preámbulo de su obra, nos dice que es "hombre

49 El insigne historiador R.G. Collingwood es de la opinión que Herder es el "padre de la antropología, queriendo decir con eso la ciencia que: a) distingue varios tipos físicos de seres humanos, y b) estudia las maneras y costumbres de estos varios tipos como expresiones de peculiaridades psicológicas que se dan con las físicas" (Collingwood, R.G., Idea de la historia, México, Fondo de Cultura Económica, 2004, pp. 160-161).

50 Herder, J., Ideas para una filosofía de la historia de la humanidad, Trad. Rovira Armengol, Buenos Aires, Editorial Losada, 1959. Esta es la edición que utilizaremos en nuestro trabajo. Este libro estuvo siempre bajo la mirada atenta de Goethe, que mantuvo siempre una estrecha e importante relación de amistad e intelectual con Herder: "a ambos les eran al fin comunes la concepción de la esencia y fundamento divino del mundo, [...] como exponente de la vida" (Baur, E., Juan Godofredo Herder. Su vida y su obra, Trad. Agustín García Calvo, Madrid, Editorial Tecnos, 1968, p. 124).

51 Cf., Schmidt, G., Razón y experiencia. Estudios sobre historia y sistemas de la filosofía, Barcelona, Editorial Alfa, 1982, p. 106. 
quien escribió y hombre eres tú que lees; [es la] humanidad deber grato y primordial" $^{, 52}$.

En sentido amplio podemos adelantar que la relación entre la Bildung y el devenir histórico trae consigo la ineludible presencia de Herder ya que fue, precisamente, a partir de este autor que "la historia sin Bildung y la Bildung sin historia no son comprensibles" ${ }^{\text {53 }}$. Veamos el porqué de esta relación. Herder se dio cuenta de que lo histórico, en su estatus de acción reflexiva, alcanza su evolución no mediante el avance de la burguesía alemana que a lo sumo logró articular lo político con lo social, sino a través de la afirmación del concepto Bildung que se "caracteriza precisamente por no haber sido concebido en un sentido específicamente burgués o político, sino en un sentido primordialmente teológico" ${ }^{\text {. }}$. Al explayarse en un ambiente religioso o específicamente teológico ${ }^{55}$ se fue lentamente, introduciendo, extendiéndose hasta formar parte inmanente del quehacer cultural, social y político germano.

Más adelante, la ilustración (Aufklärung) o era de la razón amparó, en cierta medida, que el lenguaje alemán conservara la raíz religiosa (pietista) de la Bildung pero con un alcance amplio y dinámico. Pero fue con el romanticismo alemán, fundamentalmente en la filosofía de Hegel, que se fraguó la “esperanza de redención y la reivindicación de la educación [que] desde entonces [se convirtió] en la

Herder, J., Ideas para una..., op. cit., p. 11.

Koselleck, R., Historias de conceptos..., op. cit., p. 55.

Ibídem.

Ibídem. 
Bildung" "56 Todos estos 'estirones' históricos fueron los que permitieron consolidar con fuerza su permanencia orientadora en la sociedad alemana.

En este recorrido histórico tenemos que hacer un inciso importante. Aun cuando Herder se interesó por la Ilustración francesa mantuvo con ella una tenaz crítica en cuanto su marcada tendencia racionalista ${ }^{57}$, explícita o solapada negación de la sensibilidad y un peligroso giro secularista. No obstante, al proponerse transformar tanto el pensamiento teológico sobre la naturaleza humana como construir un concepto de Bildung más acorde con el sentido de humanidad se abocó a profundizar sobre la visión inmanente de naturaleza planteada por Jean-Jacques Rousseau, fundamentalmente, en sus dos Discursos ${ }^{58}$.

Es justo señalar que el pensamiento alemán, en los siglos XVII y XVIII, está embarcado en la búsqueda de una formación que esté regida por una cultura, unas costumbres, de raíz germana y que se vaya estructurando en la medida en que la época avanza y lo requiera. Y es aquí donde acotamos que Herder no está de acuerdo con la idea de que los parámetros de otra cultura -sea esta francesa, italiana o inglesa- se convierta en el marco referencial de la alemana. Incluso sostiene que no hay cabida para otra lengua que no sea la germana.

Con esta postura, el filósofo alemán adquirió fama por ser "el padre de las ideas, estrechamente relacionadas entre sí, del nacionalismo, historicismo y

Ibíd., p. 57.

57 Es un error considerar a Herder un antirracionalista. En su obra fundamental aclara que el hombre "no podía sobrevivir sin hacer uso de su razón. [Aunque una] vez que la usara, estaba abierta la puerta para mil errores y fracasos" (Herder, J., Ideas para una..., op. cit., p. 492).

58 Cf., Rousseau, J-J., Discursos a la Academia de Dijon, Trad. Antonio Pintor-Ramos, Madrid, Ediciones Paulinas, 1977. 
Volksgeist $^{, 59}$. Eso lo hace representante de la llamada revolución del romanticismo en contra del clasicismo. En este sentido, el movimiento "antimecánica, antiuniversalista y antiuniformadora llevado a cabo por Herder" ${ }^{\natural 0}$, desde una visión romántica, muestra una faceta polémica de su pensamiento que nos podría colocar ante una situación un tanto incomoda porque, aparte del relativismo subyacente, nos trae las imágenes negativas e hirientemente persuasivas de las diferentes experiencias por la que pasó la humanidad, en varios momentos históricos, a raíz de los nacionalismos. Empero, no pensamos que este sea el caso de Herder, dado que su énfasis en el «espíritu de la nación» no implica un compromiso chauvinista o xenofóbico. Se trata, más bien, de defender el pluralismo cultural al que hoy llamaríamos, con sus bemoles antropológicos, éticos y políticos, «multiculturalismo»al estilo de Charles Taylor, Will Kymlicka, Michael Walzer, entre otros.

La «cultura» “tuvo primero que germanizarse (por Leibniz y Pufendorf), lo mismo que «civilización», para poder ser utilizado como un concepto central”61 en el conjunto del pensamiento alemán. El profesor Gustavo Bueno nos comenta, que si "Herder puede considerarse como el principal instaurador de la moderna idea de cultura es precisamente [...] por la dominante perspectiva histórica que él adoptó" ${ }^{62}$. Esta opinión es cierta ya que el propio Herder nos aclara que en su obra histórica entregó “gran parte de su alma al público [revelándole] en qué se ocupó su espíritu en

59 Berlin, I., Vico y Herder. Dos estudios en la historia de las ideas, Trad. Carmen González del Tejo, Madrid, Editorial Catedra, 2000, p. 191.

60 Rodríguez, A. Identidad lingüística y nación cultural en J.G. Herder, Madrid, Editorial Biblioteca Nueva S.L., 2008, p. 102.

61 Koselleck, R., Historias de conceptos..., op. cit., p. 54.

62 Bueno, G., El mito de la cultura, Ensayo de una filosofía materialista de la cultura. Barcelona, Editorial Prensa Ibérica, 2004, p. 75. 
ciertos períodos y asuntos, qué dudas y soluciones encontró en el curso de su vida, unas preocupándole, y otras animándole" ${ }^{33}$.

Para Herder, la historia no es una recopilación de fechas o listas de reyes, tampoco una vasija de criterios universalmente válidos. En la tercera parte ${ }^{64}$ de las Ideas, desde una especie de teoría evolucionista o transformista nos explica con un gran entusiasmo como la historia pasa por edades, períodos y particularidades desde lo inorgánico pasando por lo orgánico hasta llegar al hombre. Todo se transforma y tiene un carácter teleológico: viene a ser la historia de la humanidad una cadena de la vida social y la tradición formativa desde su primero hasta su último eslabón; su fin último es la virtud de humanidad"65.

Todo se despliega porque la historia es el resultado de la interacción de dos series de fuerzas: las "exteriores que constituyen el medio ambiente humano, y una fuerza interna que sólo puede describirse como el espíritu del hombre, o, más exactamente, como el espíritu de los diversos pueblos en que se divide la homogénea especie humana" ${ }^{96}$. La interacción de estas dos fuerzas es lo que produce las culturas y cada una de ellas tiene su propia felicidad, sus propias fases e intereses. Se deben estudiar tomando en cuenta estas singularidades.

Dentro del ideal romántico, planteado por el filósofo de Mohrungen, se sustenta la fundamental unidad de Dios con el universo dentro de una gran pluralidad de

\footnotetext{
63 Herder, J., Ideas para una..., op. cit., p. 10.

64 Baur, desde una perspectiva crítica, sostiene que en la exposición histórica que Herder realiza: "resulta una y otra vez asombroso cómo su intuición genial suple la falta de fundamentos científicos" (Baur, E., Juan Godofredo Herder..., op. cit., p. 135).

65 Ibíd., p. 133.

66 Walsh, W.H., Introducción a la filosofía de la historia, México, Siglo XXI Editores, 1980, p. 159.
} 
formas culturales ${ }^{67}$. Un principio que es expresado y recogido más por el sentimiento que por la razón dentro de la mayor creación que se ha dado en el mundo: el lenguaje. Cada lengua tiene su origen propio, su particular dinámica compleja impide que se pueda pasar de una a otra con transparencia porque para "Herder, como parte de su profundo anticosmopolitismo, critica la posibilidad de comprender en todo sentido una lengua ajena" ${ }^{68}$.

Lo que más importa es "ir al manantial cristalino y puro del lenguaje, el origen de donde brota de forma natural la lengua materna" ${ }^{\circ 9}$ que juega un papel esencial para que el hombre llegue "a todas las ciencias y las artes"70, para establecer la comunicación entre los hombres y permitir las relaciones culturales, sociales y políticas. Todo esto nos permite comprender ese gran edificio conceptual que apunta a una socialización y humanización del hombre dentro de la diversidad que tiene en mente Herder. En este aspecto se aleja del «acuerdo racional» cosmopolita enarbolado por su mentor $\mathrm{Kant}^{71}$, más allá de las esferas de organización sociocultural. Lo que visualiza con claridad cómo el pensamiento herderiano defiende una concepción donde el germanismo se coloca en un lugar privilegiado de estudio.

Para Herder, el lenguaje no tiene sus orígenes en efímeras convenciones sobrenaturales o artificios sociales sino que es la marca 'natural' de los pensamientos y sentimientos de los hombres. Se trata, en todo caso, de la voz orgánica y viva del

\footnotetext{
Cf., Herder, J., Ideas para una..., op. cit., pp. 490-520.

Rodríguez, A., Identidad lingüística y..., op. cit., p. 100.

Ibídem.

Baur, E., Juan Godofredo Herder..., op. cit., p. 133.

Esta idea de Kant se encuentra desarrollada en su "Idea para una historia universal en sentido cosmopolita" en Kant, E., Filosofía de la historia, Trad. Eugenio Ímaz, México, Fondo de Cultura Económica, 1981.
} 
espíritu de los pueblos: es la suma de las energías de todas las almas ${ }^{72}$. Dentro de este universo herderiano organizado en toda su estructura y recreado lingüísticamente, el hombre debe seguir con sensatez su propio desarrollo, esto es, el estar "conformado para la «humanidad»" ${ }^{, 73}$ en un ascenso en el que se sinteticen todas sus virtudes. Para su formación cuenta, además, con su propia razón, sentimientos, historia y religión. El interés profundo mostrado por el pensador alemán tanto por el lenguaje como por el ascenso a la humanidad serán también, mutatis mutandi, las dos preocupaciones que estarán presentes en Gadamer.

\subsection{La Bildung herderiana: problemas, trazas y retos}

Hemos de partir señalando que Herder después de reflexionar sobre la situación reinante en la época de la Ilustración se plantea una ingente empresa que le permita una formación para la humanidad por lo que se propone, en su obra fundamental, una "historia del alma humana en las diversas épocas y pueblos, [...] una historia del progreso y de las fuerzas del espíritu humano, destinada a enseñar y a educar,"74.

Dentro de las diversas acepciones de Bildung, que se han dado en este trayecto histórico alemán, tenemos ésta que la concibe "de forma activa como una formación o molde que debe orientar a las personas hacia objetivos preestablecidos"75. Esto por supuesto va orientado a un determinado estatus social y político presente en el ámbito alemán. La idea que se plantea en esta definición es que existe un tipo de educación,

Cf., Herder, J., Obra selecta, Trad. Pedro Rivas, Madrid, Editorial Alfaguara, 1982, pp. 131-232.

Baur, E., Juan Godofredo Herder..., op. cit., p. 129.

Ibíd., p. 123.

Koselleck, R., Historias de conceptos..., op. cit., p. 57. 
en el sentido utilitario, profesional de instrucción, que debe poseer una establecida clase para que pueda realizar determinadas tareas políticas o sociales. Un enfoque que, como analizamos más arriba, se encuentra lejos de expresar el alcance de Bildung pero, que no obstante, permeó en todas las sociedades hasta el presente por el influjo de la ciencia y la tecnología.

En los proyectos formativos Herder, es el primero en superar "el perfeccionismo de la ilustración mediante el nuevo ideal de una «formación del hombre», preparando así el suelo sobre el que podrían desarrollarse en el siglo XIX las ciencias del espíritu históricas" ${ }^{\text {"76 }}$. Fue un esfuerzo inicial que hizo que la crítica y el espíritu pugnaran contra las pretensiones de la ilustración de eliminar los prejuicios (Vorurteile) y del positivismo de entronizar el método y la verdad como adecuación, como baremos científicos y únicas vías para alcanzar el soñado porvenir feliz; entronizó la era de lo positivo sin retorno: adiós al sufrimiento y las penurias.

Ahora bien, la idea de formación se encuentra transversalmente en el pensamiento de Herder y constituye una especie de horizonte infinito que permea el contexto cultural que el autor estudia y proyecta. He aquí sus palabras: "permanecemos con los pies en la tierra, para considerar en su extensión más amplia lo que la naturaleza conocedora de los fines y carácter de sus criaturas nos propone

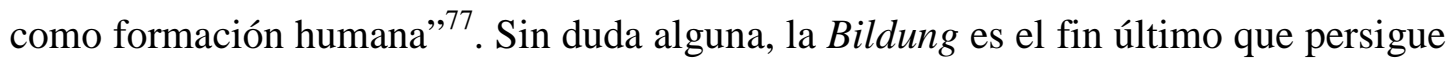
el filósofo de Mohrungen.

\footnotetext{
76 Gadamer, H-G., Verdad y Método..., op. cit., p. 37.

77 Herder, J., Ideas para una..., op. cit., p. 262.
} 
Esta formación, en el nivel más específico que Herder la perfila, se orienta hacia un tipo educación que encamine al ser humano, desde su niñez, a ir más allá de la noción axiológica que reinaba en Alemania: “jugueteo, facilitación en la enseñanza [...] utilidad en la diversas materias de estudio"78. Como existía una especie de dispersión dentro de la cultura alemana, en cuanto a la evolución del pensamiento intelectual, fue seleccionado para enfrentar esta contingencia por el margrave Carlos Federico de Baden que "había contemplado el proyecto de, por medio de una especie de parlamento de doctos, para poner remedio a la lamentable falta de un ambiente intelectual en Alemania"79.

Debido a la experiencia y la trayectoria intelectual, Herder fue elegido como la persona más idónea para ocuparse de solucionar esa embarazosa situación. La idea era que mediante el establecimiento "de un punto de reunión de varias provincias con vista a un cultivo común del espíritu y la moral" ${ }^{\text {80 }}$ se podría lograr la formación adecuada para el despegue cultural de Alemania. Una propuesta admirable en la que se conjugaba la cooperación, el sentido de pertenencia en función de valores trascendentales que impulsaran la moral, el conocimiento y todos aquellos aspectos que, como dice el propio Herder, contribuyan a la felicidad de $\operatorname{todos}^{81}$. Con todo, esta convocatoria se diluyó rápidamente debido a la confrontación entre las regiones que no lograron ponerse de acuerdo para llevar a feliz término el propósito de darle

\footnotetext{
Baur, E., Juan Godofredo Herder..., op. cit., pp. 175-176.

Ibíd., p. 176.

Ibídem.

Cf. Herder, J., Ideas para una..., op. cit., p. 10.
} 
remedio a dicha falta y finalmente conseguir una intelectualidad alemana que estuviese a la altura de su tiempo.

A pesar de las dificultades, en ningún momento de su vida Herder abandonó su 'utopía' de una formación que englobara a la humanidad entera como un proceso natural $^{82}$. Siempre mantuvo que todos los seres humanos poseían las disposiciones naturales y creadas, es decir "el lenguaje, la razón, la libertad, la tolerancia y la religión" ${ }^{83}$ para alcanzar el más fabuloso paradigma de «ser hombre». Creyó firmemente en su proyecto concreto, en la idea de llevar la educación alemana a un nivel superior con proyección universal.

La universalidad se halla implícita en todos los hombres pero se alcanza "a través de lo particular y concreto del conocimiento [...] singular de las costumbres de cada pueblo" $"$. En otras palabras, la singularidad cultural alemana: "lo provinciano, lo nacional, lo local, la lengua materna, están traspasados en la historia universal, que encamina a una misma meta llamada humanidad" 85 . En la medida en que el ser humano se arraiga en su mundo específico más descubre su pertenencia a un mundo más amplio. Los puentes son múltiples para la toma de conciencia de esta realidad: la analogía, la imaginación, la empatía, el descubrimiento de leyes a través de la razón. Todos elementos de la Bildung que impiden quedar anclados en la particularidad u obnubilados por la apariencia de cosas aisladas. Tenemos un caso de cómo funcionan

Cf., Reyes, M., Filosofía de la historia, Madrid, Editorial Trotta, 2005, p. 91.

Baur, E., Juan Godofredo Herder..., op. cit., p. 93.

Rodríguez, A. Identidad lingüística y..., op. cit., p. 68.

Ibíd., p. 78. 
estas vías que parte de la propia experiencia de Herder: "la gran analogía de la naturaleza me llevó a las verdades de la religión" $"$.

La presencia del «otro» es la otra fuente de asimilación y transmisión de la Bildung que frena al individuo en su exacerbación de individualidad. Según Herder, el hombre necesita de la alteridad para darle forma a su existencia y tomar conciencia de su puesto en el mundo o como lo formula Gustavo Bueno: "Ningún individuo se ha hecho hombre por sí mismo, dice Herder; por tanto, todos los hombres se forman gracias a la «generación espiritual» que llamamos educación" ${ }^{87}$. Relacionarse con el otro implica atención y responsabilidad.

Mediante el proceso intersubjetivo podemos detectar cómo en el pensamiento de Herder está manifiesta una formación que relaciona dialécticamente lo individual con lo social y que insiste tenazmente en que el hombre haga ese transvase existencial que le va a permitir darse cuenta de pertenecer a la humanidad y en esa medida formarse.

Visto todo lo anterior nos queda por examinar uno de los conceptos axiales de la filosofía de Herder: «ascenso de la humanidad». Este autor considera que el modelo formativo por el que él aboga para Alemania puede servir de acicate para otros pueblos. Propone un tipo de formación mediante el cual se llegue a la comprensión de "una configuración o formación según leyes eternas, que ningún capricho de los hombres modifica" ${ }^{\natural 8}$. El convencimiento le viene porque la historia

Herder, J., Ideas para una..., op. cit., p. 13.

Bueno, G., El mito de..., op. cit., p. 76.

Herder, J., Ideas para una..., op. cit., p. 43. 
ha mostrado cómo la naturaleza y las distintas culturas ajenas a la suya tienen ciertas características que le son propias pero que, en el fondo, los hombres se hallan unidos por Dios ${ }^{89}$ en una entidad de humanidad (Humanität) que se halla latente en todos y que debe desarrollarse en toda su plenitud. Herder, al reunir lo que entiende por humanidad, lo expresa como sigue: "[es] todo cuanto [...] he dicho sobre la noble formación del hombre para la razón y la libertad, para más primorosos sentidos e instintos, para una salud más delicada y robusta, para la ocupación y dominio de la tierra" 90 .

La humanidad es lo formal, lo ideal o lo abstracto general. Es una especie de eidos que nada la agota definitivamente; que supera todas las determinaciones positivas o empíricas y está por encima de cualquier irregularidad de las situaciones fácticas. Nada la detiene pero requiere ser colmada por el trabajo formativo de cada cultura, de cada época, de cada hombre, en la expansión de su ser genérico. Para Herder, todos los individuos están organizados física y espiritualmente para la humanidad.

Ahora abordaremos a Humboldt, un referente histórico imprescindible para lo que nos atañe en esta indagación: la Bildung gadameriana.

89 La cuestión de la intervención de Dios en la naturaleza y en el hombre ha sido muy debatida. Nosotros pensamos que el pensamiento de Herder está impregnado por un sentido religioso. De hecho, en el preámbulo, nos topamos con el siguiente fragmento: "Dios, que todo lo ordenó en la naturaleza según medida, número y peso, que según eso instituyó la esencia de las cosas, su figura y enlace, su curso y conversación, de suerte que desde las grandes estructuras universales hasta el grano de polvo, desde la fuerza que sostiene tierras y soles hasta el hilo de una telaraña, solo reina una sabiduría, bondad y poder, él, que también en el cuerpo humano y en las energías del alma humana lo concibió todo de un modo tan maravilloso y divino" (Herder, J., Ideas para una..., op. cit., pp. 11-12).

$90 \quad$ Ibíd., p. 119. 


\subsection{Wilhelm von Humboldt: el lenguaje en la relación mundo-hombre-Bildung}

Hemos de comenzar aclarando que Wilhelm von Humboldt (1767-1835) es un filósofo que, al igual que Herder, es poco conocido en el ámbito académico y mucho menos en el público. El impacto de su pensamiento no ha calado en el gusto de editoriales y bibliotecas por lo que ni ha sido lo suficientemente divulgado y estudiado. Sin embargo, este filósofo le ha dado un significativo aporte a la hermenéutica alemana posterior ${ }^{91}$, sobre todo a la de Gadamer. Lo que nos interesa destacar de este autor, es la manera original y persuasiva en que estableció la relación de elementos considerados tradicionalmente aislados: el lenguaje, el mundo, el hombre y la formación (Bildung). Un enlace que viene soportado por la diferenciación entre cultura como acumulación de conocimiento, producción artística o científica y formación como fuerza vital de comprender y obrar.

Se ha venido imponiendo el criterio de que para estudiar el pensamiento de Humboldt hay que relacionarlo con Kant. Esto es cierto en parte porque, como dice Andrés Crelier, "el kantismo es [...] considerado como un paradigma a superar, rebatible y deficiente. En esta tarea crítica y [de] superación, los antikantianos como Hamann y Humboldt resultan profundamente kantianos"92. Lo que este crítico plantea, hegelianamente, es que la superación supone la asimilación y la síntesis que resulta de la toma de ambas partes: Humboldt cuestionando a Kant, sigue en la misma senda que éste desbrozó.

91 Cf., Crelier, A., Introducción a la filosofía Hermenéutica del Lenguaje, Buenos Aires, Editorial Biblos, 2013, p. 77.

92 Ibídem. 
Los temas abordados por Kant son a la vez referenciales y controvertidos. Hablamos de su teoría del giro copernicano en el conocimiento (las realidades no son independientes del sujeto), su cosmopolitismo republicano, su ética centrada en la libertad al margen de los sentimientos y su pasión por la ilustración (razón-universal). En todos tiene sus «anti». Lo importante es que existe una resistencia de parte de Humboldt a la ilustración (Aufklärung) kantiana en cuanto a su tendencia a lo universal debido que persigue pasar por un mismo rasero conceptual expresiones culturales muy diferentes en el estilo de vida, cultura, valores. Pero lo más preocupante era esa osadía racionalista de la Ilustración: construir una ciencia del lenguaje como una disciplina autónoma o aislada de los contextos.

El proyecto de Humboldt fue fundar una particular disciplina del lenguaje ${ }^{93}$. Esta, en forma general, consistió en pensar el lenguaje como un paradigma de toda hermenéutica y en donde cualquier experiencia humana de la realidad apunte hacia la restitución de toda una serie de opuestos a la naturaleza: sensibilidad-razón, cuerpoespíritu, hombre-mundo, conocimiento-formación. No con la finalidad de que una de las partes desaparezca o que una asimile a la otra sino que entre cada binomio se produzca una constante tensión creativa.

Pasemos, entonces, a exponer cómo Humboldt concibe el lenguaje. Empecemos por citar su célebre fórmula con la que resume la visión dinámica de lenguaje, en cierto modo, ya adelantada por Aristóteles: "no es un producto (ergon) sino una

93 Humboldt, W. (von), Escritos sobre el lenguaje, Trad. Andrés Sánchez Pascual, Barcelona, Ediciones Península, 1991. En esta obra se recogen los diferentes escritos de Humboldt en torno al lenguaje que fue un tema constante en su itinerario filosófico. 
actividad (energeia) ${ }^{\prime 94}$. El lenguaje es una creación continua, una fuerza que se va desarrollando mediante un proceso que no finaliza en el habla de los pueblos y de los hombres.

Otro rasgo axial de su filosofía lingüística es su marcada deferencia de esas corrientes que limitaban al lenguaje a procesos psicológicos de percepción y conceptualización. El problema es que independizan o priorizan la dimensión psíquica frente al espacio social y la génesis amplia del lenguaje. La consecuencia de esto es grave por cuanto no toma en cuenta la creación e interacción humanas como ámbitos del lenguaje.

El otro aspecto significativo, es que el filósofo de Potsdam pensaba que el lenguaje abriga un papel constitutivo en la evolución del pensamiento tanto en lo particular como lo colectivo. Es imposible separar el lenguaje del pensamiento; existe una determinación del pensamiento por parte del lenguaje ${ }^{95}$. Además, todo lo que se piensa tiene un referente en la realidad (objetiva o creada) en tanto lenguaje, por eso, según Humboldt, citado por Lafont, la objetividad "ve realmente su pensamiento fuera de sí mismo, lo cual sólo es posible en otro, es decir, en un ser que igualmente tenga capacidad de representarlo y de pensarlo"96. Esta dualidad también es complicada, sólo es posible en el sujeto porque la objetividad consigo mismo se consume o patentiza cuando éste, fuente de la representación, ve efectivamente su forma de pensar fuera de sí. Con todo, en lo que quiere insistir Humboldt es que el

Crelier, A., Introducción a la..., op. cit., pp. 80-81.

Cf., Ibíd., p. 78.

Lafont, C., La razón como lenguaje, una revisión del giro lingüístico en la filosofía del lenguaje alemana, Madrid, Editorial Visor, 1993, p. 57. 
lenguaje es una manifestación de lo humano que se muestra en el pensamiento, sin obstáculos o artificios.

Humboldt está en franca oposición a la concepción clásica del lenguaje como instrumento (Werkzeug) que "lo concibe como un medio para designar objetos dados independientemente, como si el mismo conjunto de objetos y conceptos, independientes de toda conceptualización, fuera designado con palabras diferentes por cada lengua, que serían otras tantas envolturas"97. Para el autor todo se configura mediante el habla, la lengua hasta la crítica de aquellos que piensan lo contrario, “pues el lenguaje habita en el ser humano siempre de manera completa y nunca de manera fragmentaria",98.

La explicación que dio Humboldt a la inmanencia, trascendencia y posibilidades que tiene el lenguaje en el individuo va acompañada de otro presupuesto relevante: el progreso lingüístico de una persona sólo se produce si ésta se alimenta en una relación intersubjetiva. Sin el otro no existe sociedad, ni habla sino aglomeraciones. Incluso un concepto “alcanza su determinación y claridad sólo mediante su reverberación en la capacidad pensante de un prójimo. El concepto se genera al desprenderse de la móvil masa del representar y se torna un objeto para el sujeto" "99 El lenguaje únicamente se desarrolla en sociedad y un ser humano "sólo se entiende a sí mismo al comprobar tentativamente la inteligibilidad de sus palabras

Crelier, A., Introducción a la..., op. cit., p. 78.

Humboldt, W., Escritos sobre el..., op. cit., pp. 69-70.

Lafont, C., La razón como..., op. cit., p. 57. 
dirigidas a los otros"100. Emerge constantemente la condición de entendimiento porque lo vitaliza en cada conversación.

Dentro de su "forma interna (innere Sprachform), el lenguaje es un constituyente fundamental del espíritu humano" ${ }^{101}$ y en este sentido permite la intersubjetividad como condición precedente tanto de la objetividad como de la subjetividad. Esto es bien importante ya que nuestro autor formula una primacía en el ámbito del "diálogo (Wechselrede)"102 con respeto a la "lógica que permite comprender esa correlación lingüística intersubjetiva ante la relación cognoscitiva "sujeto-objeto"103.

Lo que los sujetos hablan se relaciona con su «mundo»y para que pueda "conformarse un mundo de objetos, es preciso que haya una estructura intersubjetiva" ${ }^{104}$. En el pensamiento humboldtiano, los objetos dados en la realidad no son independientes del sujeto que lo determina porque el lenguaje es un órgano que, como expusimos más arriba, refrenda el pensamiento y podríamos también añadir, la realidad; el lenguaje forma parte constitutiva del mundo ${ }^{105}$ o mejor dicho, los distintos lenguajes son variadas visiones del mundo. En palabras de Humboldt, la “esencia de la lengua consiste en verter la materia del mundo fenoménico en el molde de la forma de los pensamientos" $" 106$.

100 Ibídem.

101 Leroy, M., Las grandes corrientes de la lingüística, Madrid, Fondo de Cultura Económica, 1974, p. 46.

102 Lafont, C., La razón como..., op. cit., p. 58.

103 Crelier, A., Introducción a la..., op. cit., pp. 80-81.

104 Ibídem.

105 Cf., Ibíd., p. 77.

106 Humboldt, W., Escritos sobre el..., op. cit., p. 46. 
Ahondando más apuntaríamos que "el lenguaje es un absoluto que marca los límites del mundo, pues coincide necesariamente con estos límites del mundo y determina lo que aparece en él"107. Para él la determinación del lenguaje debe intervenir en la formación conceptual inevitable para comprender las cosas y sus implicaciones recíprocas de aquello que se exclama sobre el mundo. No obstante, es una posibilidad y al mismo tiempo una perspectiva, porque según Humboldt el pensamiento no es que sea dependiente del lenguaje sino una suerte de lenguaje particular y categórico, ya que la multiplicidad de perspectivas del mundo tiene su equivalente, finalmente, en una diversidad de $\operatorname{mundos}^{108}$.

Si lo entendemos de esta manera, el lenguaje es abordado como un problema difícil de afrontar, donde el pensador alemán señala su importancia en el ámbito social, como el expresivo, e igualmente toma en cuenta la sensibilidad como vehículo de la percepción con implicaciones en el entendimiento humano. La riqueza, las perspectivas y densidad del pensamiento de nuestro autor es lo que ha hecho de él una referencia ineludible sobre el problema del lenguaje a lo largo del siglo XX.

Hemos visto cómo Humboldt logra constituir una relación mundo-hombreBildung movilizando, desde un proceso consciente, compartido y transformador, dicha correlación y todo permeado por el lenguaje. La vida formativa consiste en una verdadera apropiación y constante transformación del mundo. Esta idea de fondo la canalizó el autor por una vía teórica y una práctica aclarando con ambas qué es y cómo se produce la Bildung.

107 Crelier, A., Introducción a la..., op. cit., p. 82.

108 Cf., Ibíd., p. 83. 
En el plano teórico tenemos que resaltar que en Humboldt, la formación (educación) tiene que ver con el «carácter» que, según el filósofo, "no equivale al sometimiento de los fenómenos a una ley, sino que es el acercamiento del ente a un ideal" "109. Utiliza la expresión Bildung des Gemüths ${ }^{110}$ para dar cuenta de que no se trata sólo de formar el intelecto saturándolo de conocimientos o preparándolo para el éxito social sino que hay que ir a fondo y abrir caminos por el que transite libremente el espíritu. El hombre tiene que ser visto en su totalidad en donde se compaginen armoniosamente la razón, los sentimientos y la voluntad; han de desarrollarse todos sus talentos innatos.

La formación se fortalece cuando la comprensión teórica y voluntad práctica interactúan en la misma dirección para el logro de fines superiores: el bien, la libertad, la felicidad, tanto en el espacio particular como en el colectivo. El otro medio que Humboldt considera determinante para el despliegue del estado de ánimo $(\text { Stimmung) })^{111}$ es el arte. Su ventaja es que como medio persuasivo suscita en el hombre un tipo de orientación vasta, es decir, lo espolea hacia la universalidad de la naturaleza y del hombre. A través de la representación de un ideal, el expectante aprende a distinguir lo esencial de lo efímero o accidental.

En la esfera práctica, Humboldt presentó en 1809 una solicitud para fundar una universidad en Berlín pero estableció sus tareas: "garantizar la «educación y Bildung

109 Humboldt, W., Escritos sobre el..., op. cit., p. 83.

110 Nos ha sido de mucha utilidad, para este punto específico, el artículo de Ute F., "La educación del corazón", en Humboldt 158, Goethe-Institut, diciembre 2012, pp. 15-17

111 Las reflexiones de Humboldt acerca de la cuestión estética se hallan en "Estudios estéticos sobre el Hermann y Dorotea de Goethe". 
nacional»"112. Al igual que con este ejemplo y otros en la misma tónica, el filósofo mantuvo siempre que el Estado no debe actuar con despotismo: ese ambiente homogéneo y asfixiante que 'espanta' toda iniciativa privada. No puede regimentar la vida de los individuos en todos los ámbitos porque esto incentivaría la competencia, el egoísmo y los resentimientos. El Staat, más allá de la seguridad, debe ser garante de la formación de sus ciudadanos, de la conservación de las buenas costumbres y garantizar que todos procedan con libertad. El actuar libre, para Humboldt, hace mejores a los seres humanos porque pone de manifiesto un requisito que les es inherente $^{113}$.

El estudio que hemos realizado en compañía de Koselleck nos ha permitido un recorrido por los contextos y los significados más relevantes de Bildung con la finalidad de tener una comprensión amplia y de peso de la misma. Desde este soporte histórico-semántico nos adentraremos, en el próximo capítulo, a estudiar a uno de los pensadores más importantes del idealismo alemán y que más ha influido en nuestro tiempo en variados temas: G.W.F. Hegel. Sus trazas en filosofía (dialéctica), en antropología (Bildung) y en historia (tradición) han sido categóricas en la hermenéutica dialógica de H-G. Gadamer.

Berlin, I., Vico y Herder..., op. cit., p. 58.

113 Todas estas ideas se encuentran en uno de los textos de Humboldt que salió póstumamente (1851). Nos referimos a Los límites de la acción del Estado, Trad. Joaquín Abellán, Madrid, Editorial Tecnos, 2009. Los capítulos más relacionados con la formación son el VI y el VIII. 


\section{CAPÍtULO II}

\section{LA BILDUNG EN LA FILOSOFÍA DE G.W.F. HEGEL}

\subsection{El hombre en su singularidad}

Dedicaremos este apartado a exponer las distintas aristas filosóficas que toma en cuenta G.W.F. Hegel al abordar el tema de formación y, al mismo tiempo, intentaremos extraer de esa diversidad los rasgos que consideramos esenciales en nuestra investigación. Esto servirá para comprender el proceso que se va fraguando en el pensamiento hegeliano y las implicaciones ético-políticas que tiene para la historia del pensamiento centrado en el hombre.

La Bildung tuvo gran relevancia en la concepción cultural alemana del siglo XVIII y cuya idea fundamental era forjar en el hombre una forma de ser donde confluyan lo desconocido con lo conocido, esto es, se dé una dialéctica entre lo inculto y lo culto. Hegel es partícipe de este mundo cultural pero su influencia ha sido tal que su concepción al respecto se presenta como antecedente ineludible para algunos filósofos contemporáneos que trabajaron igualmente ese concepto alemán ${ }^{114}$.

Como el objetivo central de este apartado es analizar el concepto de Bildung en Hegel, es conveniente trazar la pauta principal desde la cual se inscribe nuestra incursión teórica. En el itinerario intelectual medular de este autor, la filosofía "arranca al hombre de su anclaje en el ámbito de lo habitual y convencional para

114 Entre uno de estos pensadores está el filósofo alemán Hans-Georg Gadamer, autor central de nuestra investigación y al que nos referiremos con más precisión en el siguiente capítulo. 
dejarlo expuesto a lo cuestionable"115 y a un negarse a sí mismo (como independiente). El hombre es un ser menesteroso, necesitado, dependiente, que "requiere del trabajo ajeno para poder satisfacer la totalidad de sus necesidades"116. En palabras del propio Hegel: “[e]l individuo singular [...] es el espíritu inacabado, una figura concreta, en cuyo total ser allí domina una determinabilidad"117. En fin, es un ser finito en permanente hacerse que, en su «pasar a otro», le incumbe formarse y ampliar su conciencia hasta llegar a niveles de universalidad.

Desde esta premisa clave es necesario determinar cómo concibe Hegel el recorrido formativo. El estudioso E. Fink nos da la pista al respecto al apuntar que "Hegel comienza el examen del pensar que concibe el ser con la certeza sensible"118. Así que nosotros haremos lo mismo: partir de la inmediatez o singularidad que se inicia sin que el individuo esté consciente de ello.

Para Hegel, en el desenvolvimiento de la Bildung humana se da un difícil y complicado tránsito donde finalmente triunfa la autoconciencia en sus expresiones más altas (filosofía). El desarrollo se manifiesta en la figura del «espíritu» (der Geist) desde su singularidad o conciencia sensible hasta su ascenso a lo universal; es la odisea o actividad y creación de este espíritu en su estar en el mundo. En la Fenomenología del Espíritu (Phänomenologie des Geistes), escrita en 1808, Hegel enfoca su objetivo hacía el Espíritu absoluto. De acuerdo con Ricardo Sánchez, cree

115 Fink, E., Hegel. Interpretaciones fenomenológicas de la Fenomenología del Espíritu, Trad. Iván Ortega Rodríguez, Barcelona, Editorial Herder, 2011, p. 15.

116 Vásquez, E., Ciencia y dialéctica, Guarenas, Fondo Editorial el Búho de Minerva, 1988, p. 86.

$117 C f$. Hegel, G.W.F., Fenomenología del Espíritu..., op. cit., p. 21.

118 Fink, E., Hegel. Interpretaciones fenomenológicas de..., op. cit., p. 89. 
que esta obra se podría comparar con una Bildungsroman ${ }^{119}$ o novela de formación. La odisea que desarrolla el filósofo de Stuttgart para lograr ese arduo y penoso itinerario debe pasar por el espíritu subjetivo y el espíritu objetivo que son las dos figuras esenciales antes de lograr el objetivo final que es el espíritu liberado de mundo temporal, del tiempo y de lo sensible.

Hegel, desde el espíritu subjetivo, nos explica cómo el hombre se va formando partiendo de su singularidad y en un itinerario que hace la conciencia a través de la experiencia ${ }^{120}$ de configurarse. La pregunta de fondo es ¿cómo el individuo logra salir de la inmediatez y formarse o cómo consigue el ascenso a la universalidad? Para dar respuesta a esta interrogante es necesario ir observando cómo logra el individuo formarse a través de las figuras o momentos dialécticos y tiene que ver en cómo se da la formación del concepto (Begriff) $)^{121}$ y cómo la conciencia individual comienza su recorrido por los momentos o etapas. Hay que mencionar, además, que nuestro filósofo en el prólogo (Vorrede) nos comenta que en "el comienzo de la formación y del remontarse desde la inmediatez de la vida sustancial tiene que proceder siempre

119 Sánchez R., “La Fenomenología del Espíritu como Bildungsroman?” Eikasia Revista de Filosofía, año III 15, Valladolid, Diciembre del 2007.

120 En realidad Hegel llamó a su Fenomenología del espíritu inicialmente la Ciencia de la experiencia de la conciencia. Su sistema filosófico tiene como objetivo central, comprender la autoconstrucción de la idea ya que la Fenomenología se hace presente como ciencia de la experiencia de la conciencia y por lo tanto, es el viaje que hace la conciencia configurándose, formándose, manifestándose y, en este sentido, alcanza al espíritu siendo ella misma espíritu.

121 Eduardo Vásquez señala que para "explicar la génesis del concepto tenemos que pasar por el ser (los sentidos), luego por la esencia (una mezcla de determinaciones de los sentidos y del pensamiento) hasta llegar al concepto (el pensamiento liberado de la sensibilidad y que ha logrado sintetizar las oposiciones). Es la razón, esto es, la realización de todas las determinaciones del pensamiento, convertidas en mundo existente. El concepto se convierte en Idea: Unidad entre las determinaciones subjetivas y objetivas". (Vásquez, E., Hegel un desconocido, Mérida, Consejo de publicaciones, Universidad de los Andes, 1998, p. 143). 
mediante la adquisición de conocimientos" ${ }^{\prime 22}$, punto que también es enfatizado en su introducción (Einleitung) ${ }^{123}$ en la que se ocupa de explicar cómo el hombre desde su inmediatez logra el saber (Das Wissen). Esto habría que tomarlo en un sentido amplio si se considera al individuo en una formación cultural extensa y en su inmanente carácter universal y espíritu autoconsciente.

El hombre, en su condición singular, debe recorrer un camino tortuoso ya que es precisamente en este transitar, con sus fases, donde él se va formando. Se trata de que cada conciencia singular de acuerdo con dichos momentos, logre lo universal, es decir, formarse.

Según Hegel "el individuo singular tiene que recorrer, en cuanto a su contenido, las fases de formación del espíritu universal, pero como figuras ya dominadas por el espíritu" ${ }^{124}$. Cada fase debe ser aprehendida en su totalidad por el espíritu para que facilite su ascenso a lo universal, tomando en cuenta que "el espíritu es libertad, en cambio, la naturaleza pertenece a la esfera de la necesidad que es también contingencia (Zufälligkeit) ${ }^{\natural 125}$. Nuestro filósofo, como la gran mayoría de los pensadores románticos tienen la inquietud por la cuestión de la formación y, específicamente de la educación, por tanto, le preocupa cómo llega el espíritu a ser libre. Es un problema que no se puede dejar de lado o soslayar y que es una

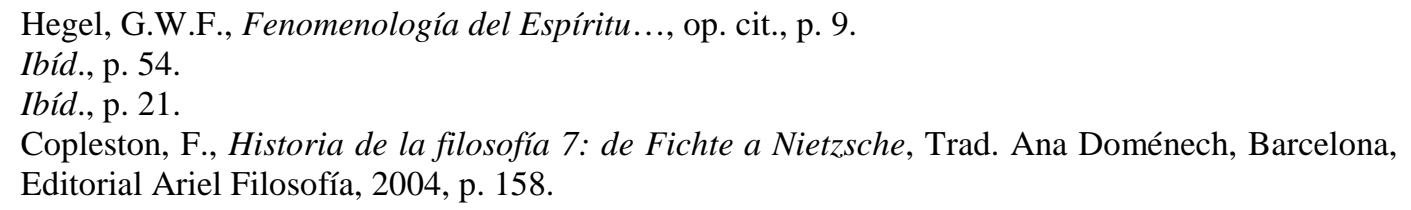


responsabilidad filosófica abordarlo como un punto esencial para la comprensión del hombre en su totalidad.

El filósofo de Stuttgart intenta responder a esta cuestión y se pregunta cómo el hombre ha llegado a ser lo que es. Afirma que es un proceso donde la experiencia (Erfahrung) y la historia (Geschichtswissenschaft) están presentes configurando y desarrollándolo. Hay que mirar hacia atrás, al pasado, para entender cómo se ha ido avanzado y cómo se ha llegado a determinada condición o a ser de cierta manera. En este sentido, el profesor Eduardo Vásquez, citando a Hegel, señala que "lo que en épocas pasadas preocupaba al espíritu maduro de los hombres desciende ahora al plano de los conocimientos, ejercicios e incluso juegos propios de la infancia"126. El hombre está orientado históricamente a cincelar a través de la historia esas "etapas progresivas pedagógicas" ${ }^{\text {"27 }}$. Pasando por las figuras del espíritu desde la inmediatez nada se pierde de su enseñanza porque en cada etapa se aprehende el conocimiento del pasado y este se fusiona con lo nuevo "de ese modo, el individuo es formado al adquirir la cultura ya formada" ${ }^{228}$. Tenemos, entonces, que Hegel concibe la sustancia inorgánica por formación que sólo se trasmuta una vez que el individuo es consciente de sí.

Es aquí donde entramos a tomar en consideración al «Espíritu objetivo» porque pensamos que es en esta figura donde el hombre una vez ha hecho el recorrido desde la inmediatez partiendo del espíritu subjetivo se hace consciente de su formación; una

126 Vásquez, E., Filosofía y Educación, Mérida, Consejo de publicaciones Universidad de Los Andes, 1994, p. 91.

127 Ibídem.

128 Ibíd., p. 92. 
vez que finaliza la fase de la conciencia natural se da inicio al difícil mundo existente tanto en sus leyes, instituciones como el Estado. En el caso del individuo se expresa, como señala Vásquez, "en forma de ideas, conceptos, prejuicios, costumbres"129. El espíritu objetivado adquirirá conciencia de sí mismo, saber de sí desde donde surgirá la reflexión.

En cuanto a la conciencia colectiva que es la fase donde el hombre una vez ya formado logra su ascenso a lo universal "Hegel lo hace recorrer las mismas etapas de la filosofía que culminan en el idealismo absoluto. Es en esto lo que consiste la formación o la cultura (Bildung)" ${ }^{\text {"130 }}$. A través de ella se desarrolla la conciencia y lo hace desde lo más abstracto para educar al individuo, a la conciencia singular. Así, detallando minuciosamente cada instante en el desarrollo de la conciencia desde su singularidad, el espíritu se va formando lentamente.

La forma como Hegel comienza su exposición es La conciencia: El saber (Das Wissen). Es la primera figura de la conciencia o la certeza sensible (Die Sinnliche Gewißheit), pero ¿saber de qué? saber de lo inmediato de un ser replegado sobre sí mismo. Tenemos certeza de cosas que nos rodean mas no sabemos aún qué son, creemos tener un conocimiento rico pero en realidad es el más pobre, es el saber para la conciencia. Así, Hegel habla sobre la inmediatez del saber cómo, por ejemplo, cuando nosotros los que estamos aquí sentados reflexionando y escribiendo debemos comportarnos como lo más inmediato, y sobre todo, debemos seguir la conciencia tal

Ibídem.

130 Vásquez, E., Ensayos sobre la dialéctica de Hegel, Estudios sobre la dialéctica en Hegel y Marx, Caracas, Universidad Central de Venezuela, 1982, p. 75. 
como se nos presenta en su inmediatez, nuestra percepción comienza de esta manera: sabemos o somos ciertos de cosas que están alrededor nuestro o del ser de algo que sin duda es para nuestra conciencia, ésta, se dirige al saber que es ante todo nuestro objeto es el saber al cual hace referencia a nuestro objeto, no se trata aquí de un saber cualquiera, no, sino un saber como manifiestamente lo dice Hegel "que es ante todo o de modo inmediato nuestro objeto"131. ¿Qué es lo que Hegel dice acerca del objeto? Nos dirá que el "objeto para nosotros, nuestro objeto, es el objeto para aquéllos, nosotros -los filósofos- que de antemano saben así en tanto en tanto actuamos mediando" ${ }^{\prime 132}$.

Cuando Hegel dice «nuestro» ¿A quién se está refiriendo? ¿Está aludiendo a nosotros que estamos aquí en este momento reflexionando y escribiendo en la computadora? Por supuesto que no. El autor, más bien, tiene en mente a un sujeto que conoce y aprehende este saber sobre lo que estamos indagando. No se trata de un conocimiento relativo porque no se sostendría en su inmediatez pasajera; tiene que ser un saber sobre lo sabido.

Resumiendo, en el espíritu subjetivo, la conciencia sensible parte de una conciencia ingenua donde ella se encuentra aún en su inmediatez o singularidad o como señala Palmier el "yo ha devenido nosotros, el nosotros ha devenido yo" 133 esa es la dialéctica que ha sido elaborada con sus contradicciones, que ha transitado por la inmediatez o su ser natural para llegar al saber de sí. Vásquez hace notar que "la

131 Hegel, G.W.F., Fenomenología del Espíritu..., op. cit., p. 63.

132 Heidegger, M., La Fenomenología del Espíritu de Hegel, Trad. Manuel E. Vásquez y Klaus Wrehde, Madrid, Alianza Editorial, S. A., 2012, p. 74.

133 Palmier, J., Hegel, Trad. Juan José Utrilla, México, Fondo de Cultura Económica, 2006, p. 53. 
conciencia es esencialmente pensamiento entonces es el pensamiento mismo el que conoce al pensamiento. Así se realiza la unidad entre la conciencia singular y la autoconciencia universal" ${ }^{\prime 134}$. Una vez arribados aquí, hemos constatado a través de la Fenomenología del Espíritu cómo se da el desarrollo de la figura del Espíritu atravesando la experiencia de la conciencia (Erfahrung des Bewusstseins) hasta elevarse de lo particular a lo universal.

Pero queda algo más que decir aquí porque en la medida en que vayamos avanzando y veamos otra idea de formación que encontramos en este libro de Hegel, nos daremos cuenta de la riqueza de su pensamiento. En el capítulo de «Autoconciencia» el filósofo alemán llama a este inciso La formación cultural para dar cuenta de la labor diaria que configura el ser del hombre, es decir, lo extrae de su inmediatez y lo eleva a la universalidad. La idea es la misma que hemos venido exponiendo como un estribillo. Hegel concibe al individuo como "un ser inacabado e incompleto que va formándose a sí mismo con el trabajo propio, que va formando los mundos en que vive, y, al mismo tiempo, formando conciencia del proceso en que él se va formando" 135 .

Para el pensador alemán el trabajo formativo se ve claramente en la relación dialéctica amo-esclavo en donde éste se pone en función de aquél. Así vemos, cómo la disciplina saca al esclavo de su inmediatez, es decir, de su estado de naturaleza elevándolo a lo universal en un decurso formativo ${ }^{136}$. En cuanto a la cuestión del

\footnotetext{
Vásquez, E., Filosofía y Educación..., op., cit., p. 76.

Ibíd., p. 99.

Ibíd., p. 113.
} 
deseo o «certidumbre de sí» es dejado a un lado por el esclavo por temor al amo: prefiere la vida a la libertad. Es precisamente a partir de este temor a la muerte que el esclavo se atreve a dominar sus impulsos y logra por medio de su voluntad ${ }^{137}$ salir del estado de naturaleza. Esto es sumamente importante porque para Hegel, sin "la formación, el temor permanece interior y mudo y la conciencia no deviene para ella misma" $" 138$.

El esclavo por medio del trabajo logra que su conciencia se transforme en autoconciencia, se eleva de la sumisión a la autonomía. Al reconocer al amo (que no teme a la muerte) se establece una "comunidad de intereses entre los hombres, pues el esclavo tiene que ser mantenido vivo por el amo para que este a su vez pueda satisfacer sus necesidades" ${ }^{139}$. Tanto el uno como el otro son esenciales para la formación de la totalidad de los hombres que se instituye, precisamente, por esta «lucha por el reconocimiento».

Si preguntáramos después de este encuentro de conciencias ¿cuándo en realidad son libres?, Hegel respondería que ambos logran su libertad cuando declinan a su egoísmo, es decir, dejan de exaltar su propia personalidad egocéntrica y constriñen sus deseos personales. El esclavo a través de la disciplina y el amo cuando deja de envilecerse en el goce. Sólo la falta de formación hace que el hombre se abandone "a la ira y actúa ciegamente movido por esta pasión, porque considera en

137 Debemos aclarar aquí que quien en realidad actúa es la voluntad del amo como excelentemente lo dice Eduardo Vásquez "La represión del deseo lo eleva por encima de la naturaleza, lo educa o lo forma pues ser educado es dominar sus tendencias o impulsos, no estar sometido a ellos, sino sometido a la propia voluntad (Aunque a través del esclavo lo que actúa es la voluntad del amo)". Vásquez, E., Ensayos sobre la..., op. cit., p. 105.

138 Hegel, G.W.F., Fenomenología del Espíritu..., op. cit., p. 121.

139 Vásquez, E., Ensayos sobre la..., op. cit., p. 109. 
ello una ofensa o un perjuicio" ${ }^{140}$. El ser humano debe concertar su doble condición, por un lado la animalidad y por la otra la racionalidad y así lograr que ésta última sea la que predomine para que consiga regular o dominar su ser.

Ahora bien, aún nos falta revisar otro texto de Hegel: los Escritos pedagógicos. En esta reflexiones ocasionales y oportunas se encuentra, en nuestra opinión, compendiada su idea de lo que entiende por Bildung. Sin embargo, debemos hacer un breve inciso antes de continuar. El autor tiene la preocupación de cómo la sociedad alemana de su época con su enorme crisis social y debido a su poca claridad cultural reinante no se haya permitido una Bildung que la saque del marasmo, es decir, que la revise, fortalezca y oriente. Esta situación obligó a los pensadores románticos y, sobre todo al propio Hegel a avocarse a una tarea formativo-pedagógica. Éste piensa que debe conducir a los individuos, tomando en cuenta que: "la disciplina es verdaderamente la educación seria y buena, que justamente ella logra el efecto de despojar[los] de lo natural y del egoísmo sobre todo mediante la formación intelectual" ${ }^{141}$. Estas palabras son significativas, pues formarse permite que el hombre logre reprimir o sustraer de sí su condición natural, aislada y actuar racionalmente nutriéndose y superando dialécticamente su propia cultura. Un individuo con formación es quien sabe imprimir una impronta de universalidad a su individualidad.

140 Hegel, G.W.F., Escritos Pedagógicos..., op. cit., p. 183.

141 Hegel, G.W.F., Lecciones de filosofía de la religión, Vol. 3, Trad. Ricardo Ferrara, Madrid, Alianza Universidad, 1987, p. 37. 
Los Escritos Pedagógicos marcan una época, un hito en el pensamiento de Hegel, su actividad docente en el Gymnasio excede en su capacidad a otros idealistas de su tiempo; en el periodo de Nuremberg (1809-1815) es donde se dedica a la enseñanza de la filosofía. No llevó una sistematicidad sobre los temas de educación quizás porque no le interesaba, de ninguna manera, ganar notoriedad sobre este asunto. Su interés primordial era mostrar taxativamente que el hombre llega a ser lo que es mediante la formación.

Aunque para Hegel el devenir de la Bildung se identifica con el suceder del espíritu, tenemos que tomar en consideración que la relación de ambos procesos es más complicada de lo que parece, pues como hemos visto más arriba, el último tiene una acepción mucho más amplia. Al respecto escuchemos el comentario que hace Arsenio Ginzo: "[Hegel] procura deslindar dos movimientos distintos en el proceso de autoformación del espíritu: frente al desarrollo general del espíritu se ha de distinguir el movimiento de la educación como tal, pues éste constituiría un proceso" ${ }^{\prime 42}$ que describe tan solo a los sujetos particulares, en tanto que logran alcanzar una existencia racional, vale decir, el ascenso al espíritu universal.

A pesar de esta distinción tan sutil se puede ver que en el fondo, según Hegel, se produce un profundo lazo entre el espíritu universal y el espíritu individual. Una conclusión lógica si se parte del contexto hegeliano. Frente a una dimensión pedagógica empobrecida nuestro autor propone una apertura a nuevos horizontes para la humanización de la sociedad. No duda en exponer esa esfera auténtica

142 Hegel, G.W.F., Escritos Pedagógicos..., op. cit., p. 16. 
(authentisch) de su actividad filosófico-educativa desde una plena libertad expositiva dada su situación de rector del Gimnasio.

El siguiente aspecto, al que se debe prestar atención por ser una variación reveladora de los puntos tratados, tiene que ver con la doble condición en la cual el individuo está inmerso. Hegel, en los escritos arriba mencionados, expone dicha situación cuando nos dice que el hombre "en cuanto individuo se relaciona consigo mismo. Él posee la doble vertiente de su singularidad y la de su ser universal"143. Así, el individuo al relacionarse consigo mismo sólo cuida de sí en tanto su ser particular, está pendiente de sus necesidades primarias más elementales atendiendo a su conservación física. En cambio, su condición universal tiene que ver más con el cultivo de sí mismo, con su formación.

Esto nos lleva a la pregunta de ¿cómo se eleva y cómo se da el proceso hacia la universalidad, si tomamos en cuenta el carácter racional? Hegel es claro al instar que “el hombre debe armonizar esta su doble vertiente, adecuar su singularidad a su dimensión racional o hacer que esta última sea la dominante" ${ }^{144}$. Ese arduo trayecto que debe recorrer el hombre en ese complicado entramado que es la cotidianidad es el ámbito de sentido que lo forma. Su relevancia consiste, precisamente, en el recorrido que hace estando consciente de sí mismo.

En este mismo orden de ideas, Hegel nos da a entender la preeminencia que tiene el controlar las pasiones y la ira, porque es propia de una formación adecuada que el hombre esté en capacidad de dominarlas. El control es un signo de que el

143 Ibíd., p. 183.

144 Ibídem. 
hombre ha logrado ir más allá de los desbordes de sus impulsos naturales; que la conciencia alumbra la oscuridad en la que el actuar pueda estar; que la educación ha hecho su efecto en el espíritu; que el aquí y ahora es trascendido por la posibilidad y, finalmente, que el yo cuenta con los otros para compensar necesidades y proyecta el futuro.

El tema de formación que desarrolla Hegel, a partir de su idea pedagógica, tiene significados trascendentales, imbricados y dinámicos. Aunado a todo lo anterior nos queda por ver lo que son, para el autor, la formación teórica y práctica; dos conceptos que se complementan entre sí y es lo que impulsa a los individuos a elevarse a lo universal.

La formación teórica "pertenece, además de la diversidad de la determinabilidad de los conocimientos y de la universalidad de los puntos de vista desde los que se han de enjuiciar las cosas, el sentido para los objetos en su libre autonomía" "145. Aquí se plantean tres cosas que se han mantenido hasta la época actual: 1) el reconocimiento de toda producción intelectual; 2) la íntima relación entre la pluralidad de las visiones y la aspiración a la universalidad de la comprensión en cuanto a lo que es relevante al ser humano y 3) la puesta entre paréntesis del interés subjetivo a la hora de reconocer la autonomía de las cosas.

Especificando un poco más, vemos que la «determinabilidad» consiste en que el hombre aprende a apartar de sí la inmediatez de su punto de vista que considera importante con la finalidad de alcanzar "una mayor comunidad de conocimientos con

145 Ibíd., p. 184. 
otros hombres" $" 146$. Concientiza que la alteridad propia de su naturaleza requiere estar con los otros si busca elevarse con provecho a la universalidad. Es, pues, este paso que sirve de trasfondo para formarse. Aparte de que al distanciarse “de sí mismo [...] llega a diferenciar lo esencial de lo inesencial"147, esto es, llega a saber cómo relacionar los juicios que se forma de las cosas con respecto a la realidad, a saber vincular una reflexión con la autonomía que supone trascender el interés en particular. En fin, como diría Hegel: “[un] hombre formado sabe a la vez los límites de su capacidad de juzgar" ${ }^{148}$. Hemos de aclarar que el conocimiento universal que el hombre requiere para transformarse, con el paso del tiempo, hasta llegar a ser lo que es se debe a que persigue un objetivo esencial: la libertad.

En cuanto al significado de la formación práctica, Hegel lo relaciona con un formarse a sí mismo (Selbsttraining) que compete a todos los individuos dentro de un espíritu universal. Tiene como base la «conservación de sí mismo» como el deber fundamental de cualquier individuo. Es velar por su vida o cubrir sus necesidades naturales básicas por lo que está determinado por su estado de naturaleza. A raíz de la formación práctica el hombre satisface sus necesidades e impulsos que le son naturales pero con discreción y moderación. En términos hegelianos, el hombre debe salir "de lo natural, liberarse de él, 2) por el contrario, debe estar sumido en su profesión, lo esencial, y, por consiguiente, 3) no sólo ser capaz de reducir la
Ibídem.
Ibídem.
Ibíd., p. 185. 
satisfacción de lo natural a los límites de la necesidad"149 sino, esencialmente, dedicarse a sus deberes potenciales.

El hombre que es consciente de su ser natural y de sus restricciones sabe discernir lo que lo determina que no es más que su ser originario en crecimiento. Esto no lo limita en su libertad pues reconoce dicha condición racionalmente y lo asume responsablemente, ya que sólo estaría obligado "en la medida en que él se crea ocurrencias y fines fortuitos y arbitrarios en contra de lo universal" ${ }^{\text {150 }}$. Por lo tanto, el tema central es la moderación aprehendida. Un hombre debe aprender a lidiar con la cuestión propia de su cotidianidad, pues, resulta fundamental que en la forma habitual de su estar en el mundo y en lo que le toca a su cuidado personal tiene que velar por su "salud, $[\ldots]$ una condición esencial para la utilización de las fuerzas espirituales con vista a la realización de [un] destino superior" ${ }^{\prime 151}$.

En síntesis, podemos decir que el proceso de formación hegeliano inherente en el individuo tiene en un primer momento el salir de la inmediatez, pero se necesita en esta transición ser prudente y tener consciencia de la situación. Para Hegel, sólo mediante "la circunspección se encuentra uno con el espíritu fuera de su estado, de la sensación o de la ocupación”"152. Lo que más le interesa al filósofo de Stuttgart es que el individuo prudente debe estar constantemente al tanto de las circunstancias de la vida porque solamente desde este estado de vigilancia se puede hablar de formación.

Ibídem.

Ibíd., pp. 185-186.

Ibíd., p. 186.

Ibídem. 
La acción (Bügelriemen) consciente y el pensamiento abierto de los hombres es lo que Hegel cataloga de historia que es la verdadera y real pedagoga ${ }^{153}$ de la vida.

Ahora iremos tras los pasos del Espíritu objetivo (Zielstrebigkeit) y su consecuente ascensión a lo universal para seguir estudiando el desarrollo formativo humano. Es la segunda figura que integra la filosofía hegeliana del espíritu.

\subsection{La formación como «ascenso a la universalidad»}

Empecemos por señalar que Hegel desarrolla la noción de Bildung en el contexto del Espíritu objetivo. En esta etapa el hombre se percata del resultado de su creación y de su transitar a través de la conciencia, con su consiguiente arribo a la conciencia de sí (Selbstbewusstsein) o como lo expresa Palmier: "el sujeto [...] ya no es la conciencia individual, sino la humanidad. El individuo es ahora un mundo, y el Espíritu se encarna en la vida ética de un pueblo" ${ }^{, 154}$.

El Espíritu objetivo se subsume bajo tres categorías fundamentales, producto de ese proteo devenir de la experiencia de la conciencia. No nos detendremos aquí a desarrollar detalladamente cada estadio, sino más bien resaltaremos aquellos aspectos que más interesan para la dilucidación del tema formativo. Tenemos, entonces, que el primero es el Derecho cuyo punto de partida es la voluntad individual libre y su esfera exterior es la propiedad privada y en tanto se tiene y ejercen los derechos se es

153 Vásquez, E., Filosofía y Educación..., op. cit., p. 98.

154 Palmier, J., Hegel..., op. cit., p. 54. 
persona $^{155}$; el segundo es la Moralidad, que permite la interiorización de las leyes del sujeto y el último, el más relevante para Hegel es la Eticidad (die Sittlichkeit). Ésta permite bajo la racionalización social crear la familia, la sociedad civil y el Estado. En ésta pensamos detenernos.

Lo primero que debemos advertir es que la eticidad no se puede tomar como equivalente de moralidad (Moralität). Para el pensador alemán hay una clara distinción entre estos dos conceptos que se deben destacar aquí, aunque en el uso cotidiano y hasta académico no existe una fuerte discrepancia sustancial entre estas dos maneras de abordar el problema de la acción del hombre porque tienen acepciones parecidas. El término moral, procede, según Ángel Sánchez, de la expresión latina mos-moris que originalmente se refiere a costumbre con la que también se identifica a la ética (ethos). El mismo estudioso nos dice que se podría definir moral "como un sistema de normas, preceptos y deberes que regulan los actos humanos individuales y sociales en función de la bondad o malicia de los mismos"156. Definición un tanto amplia que en vez de aclarar oscurece su distinción con la ética. A nuestro entender Hegel tiene una manera novedosa y, se podría decir, hasta polémica de entender estos dos conceptos.

Desde la perspectiva del filósofo de Stuttgart, la moralidad (Sittlichkeit) tiene una marcada distinción en su acepción con respecto a la eticidad. El crítico A. Valcárcel resalta que Hegel, en su Filosofía del Derecho, colocó estas dos categorías

155 Cf., Hegel, G.W.F., Filosofía del derecho, Trad. Eduardo Vásquez, Caracas, Ediciones de la Biblioteca de la Universidad Central de Venezuela, 1976, pp. 89-117.

156 Sánchez, Á., Introducción a la Ética y a la crítica de la Moral, Caracas, Vadell Hermanos Editores, 2009, p. 21. 
junto a una tercera en una especie de unidad triádica porque todas se relacionan directamente con la libertad (dimensión sustantiva) y el orden social (objetivo final). En otras palabras, la "[m]oralidad, derecho y eticidad, son solamente campos sustantivos dentro de otra estructura más general e importante, el Estado"157.

El problema de la moralidad, según Hegel, es que Kant la entiende como aquel ámbito o deber que se impone el individuo a sí mismo. Esto da a entender que a "diferencia de la legalidad, la moralidad no puede residir en la acción, sino sólo en su motivación: el querer" ${ }^{, 158}$ y despojada de contenido. En el pensamiento hegeliano, el contenido sólo se halla en la eticidad, esto es, en las instituciones, en las leyes y en las costumbres (ézos) vivas de una comunidad. En palabras de Hegel: "[l]a eticidad es el concepto de la libertad que se ha convertido en mundo existente y en naturaleza de la autoconciencia" ${ }^{159}$.

El ser humano es concebido, acertadamente, por Hegel como mundo ético cuando nos señala que la eticidad "es la idea de la libertad, en cuanto el bien viviente, el cual tiene en la autoconciencia su saber y su querer, y mediante cuyo actuar tiene su realidad" 160 . Por lo tanto, lo ético objetivo no es más que la idea de la libertad que se ha transformado en mundo ya existente y en autoconciencia. La idea de libertad (Idee der Freiheit) es el fin último al cual se debe. Hegel sostiene que la unidad del pensar consigo mismo y su ser universal se expresa en el pensamiento

157 Valcárcel, A., Hegel y la Ética. Sobre la superación de la «Mera Moral», Barcelona, Editorial Anthropos, 1998, p. 288. El subrayado es nuestro.

158 Höffe, O., Immanuel Kant, Trad. Diorki, Barcelona, Editorial Herder, 1986, p. 168.

159 Hegel, G.W.F., Filosofía del derecho..., op. cit., p. 185 [§142]. Las cursivas son de Hegel.

160 Ibídem. 
libre. Pero habría que tomar en cuenta, como apunta el hegeliano Vásquez, que "el contenido es tomado de afuera, es externo y así es dado al pensamiento. Esto implica que el pensamiento pueda elegir entre contenidos diferentes"161.

Si se impone al pensamiento lo que se debe hacer lleva a una contradicción que consiste en que el pensamiento queda libre pero a su vez niega su libertad desde un condicionamiento exterior. En Hegel "para que el pensamiento sea libre el contenido o la determinación tiene que ser engendrado (o puesto) por el mismo pensamiento"162 El pensar se irá autodeterminando a través de la negación que le es inmanente para que surjan así las determinaciones de la libertad ${ }^{163}$. Es el pensamiento mismo quien pone sus contenidos.

Una vez que hemos delineado la cuestión tanto de la eticidad como del pensamiento remitámonos de nuevo a la Fenomenología del Espíritu en la que Hegel nos define que la «vida de un pueblo» "es donde, de hecho, encuentra su realidad [Realität] consumada al concepto de la realización de la razón consciente de sí, donde esta realización consiste en intuir en la independencia del otro la perfecta unidad"164. La esencia inmutable de los individuos (Mannsperson) no es más que la expresión de su misma inmediatez que parece contrapuesta a ella y a la "acción de esta negatividad sobre el contenido universal [que] Hegel la llama Bildung" $" 165$ o Espíritu objetivo donde los individuos se elevan a la universalidad.

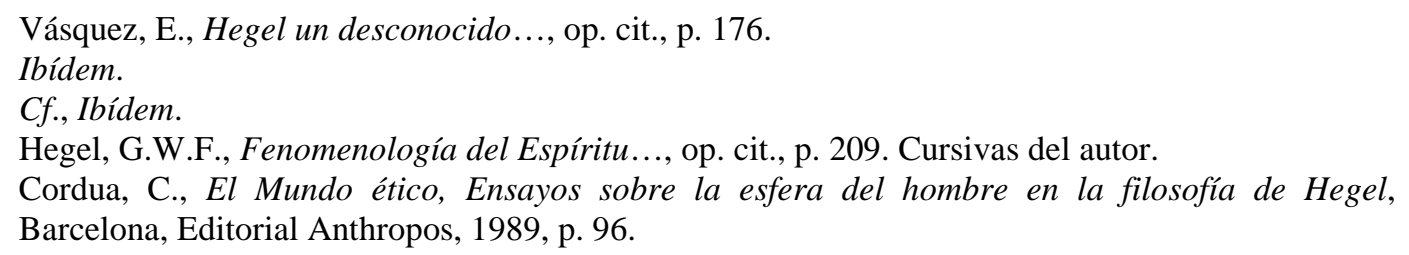


Al respecto, Carla Cordua aclara que cuando Hegel "trata el tema de la Bildung del individuo en la sociedad civil y por las instituciones políticas [...], la llama repetidamente el duro trabajo de vencer a la naturaleza" ${ }^{\text {166 }}$. Es en el arduo trabajo que cada hombre partícipe de una comunidad, partiendo de su ser natural, se transforma y convierte en "la subjetividad universal vacía, en subjetividad desarrollada"167. El punto medular es, entonces, que no es el individuo o la conciencia individual la que recorre este tortuoso camino, sino la humanidad encarnada en el espíritu, pues él es ahora un mundo formado en la vida ética del pueblo (Volk).

Hegel es taxativo en el punto de que el hombre "no se forma a sí mismo, aislado y separado, sino dentro del espíritu universal. La formación o cultura traduce al término die Bildung" ${ }^{\text {"168 }}$ de bilden que significa formar en el sentido de educar o de desarrollar las potencialidades, tal como lo apuntamos en el primer capítulo. Esta manifestación (Erscheinung) cultivada del espíritu en sus determinaciones objetivas se logra mediante la eliminación de la inmediatez o la singularidad y la ascensión a la universalidad. El profesor Vásquez lo sintetiza diciendo que la "elevación a la universalidad es la cultura (die Bildung) ${ }^{\natural 169}$.

Podríamos concluir, en sintonía con Hegel, que todo lo que ha llegado a ser el Espíritu objetivo tiene como antecedente ese proceso mediante el cual los hombres se han formado, han creado la sociedad donde habitan y a cierto nivel han regulado su

\footnotetext{
Ibíd., p. 97.

Ibídem.

Vásquez, E., Hegel un desconocido..., op. cit., p. 70.

Ibíd., p. 116.
} 
forma de estar en el mundo creando leyes para lograr el mutuo reconocimiento y la libertad. Pero ¿cómo lograron todo esto? Hegel, exclamará, a través de la Bildung.

\subsection{Variaciones: la Bildung entre lo cultural, lo histórico y la vida en común}

La afirmación de la alteridad (alter) a la que apuesta o enseña Hegel pasa por encontrar al otro tanto en su relación consigo mismo como en tanto otro como sí mismo ${ }^{170}$. Como vimos, la formación está en función de forjar en el hombre su manera de ser en la cual confluya lo cultural, y lo que se persigue con la Bildung es consolidar, concretamente, el progreso cultural del siglo XVIII y, en sentido amplio, fundar en el pensamiento del hombre (deutscher Mann) una identidad (Identität) que le dé un sentido histórico. Es un reto, por tal motivo Hegel advertirá sobre este asunto "la categoría de la educación [...] puede ser educación ascendente o deformación. [...] El hombre educado es aquel que sabe imprimir a toda su conducta el sello de la universalidad" ${ }^{\prime 171}$.

Para Hegel, el mantenimiento de los puntos de encuentro entre el pasado y el presente hace posible recolectar las expresiones culturales que subyacen en el tiempo. La Bildung responde, de hecho, al espíritu formador del hombre al delimitar los procesos en los cuales debe estar dispuesto a responder correctamente en la vida práctica y la escuela posee "una relación con el mundo real, y su cometido consiste

170 Cf. Hegel, G.W.F., Fenomenología del Espíritu..., op. cit., p. 246.

171 Hegel, G.W.F., Lecciones sobre la filosofía de la Historia Universal, Trad. José Gaos, Madrid, Alianza Editorial, 2004, pp. 69-70. 
en preparar a la juventud para el mismo. El mundo real es un todo firme, con cohesión propia, de leyes y de organizaciones que tienen como meta lo universal" ${ }^{\text {"172 }}$.

Los sujetos únicamente tienen valor desde el punto de vista formativo, en la medida en que se ajustan y logran comportarse acorde a este universal, en el cual no se anclan en sus fines. En la vida práctica, la formación se convierte en una necesidad entre los individuos y las estructuras sociales en las cuales viven, dicho de otra manera, es una entrega, un respeto a sí mismo y su cultura. Pero esto es más complejo de lo que parece, pues la voluntad "natural pasa, como la conciencia, por una serie de configuraciones a lo largo de las cuales se hace ética, o capaz de efectuarse prácticamente como mundo histórico" ${ }^{\text {"173 }}$. Es el largo proceso dialéctico (Dialektiker) que la conciencia tiene que recorrer para configurar su estar en el mundo. La idea que tiene Hegel en mente es que el individuo a través de una formación infunda valores y logre forjar a un hombre responsable, que tenga un deber consigo mismo y al mismo tiempo con los demás.

Cuando el hombre sale de la inmediatez a través de la libertad, que es donde se eleva a lo universal, comprende la particularidad de su ser. Tenemos que su "autoconciencia es primeramente simple ser para sí, igual a sí misma, por la exclusión de todo otro; su esencia y su objeto absoluto es para ella el yo" ${ }^{174}$ pero luego, con el uso de su razón, como es espíritu, logra elevarse de esta singularidad que se hace

Hegel, G.W.F., Escritos Pedagógicos..., op. cit., p. 108. Cursivas del autor.

Cordua, C., El Mundo ético..., op. cit., p. 69.

174 Hegel, G.W.F., Fenomenología del Espíritu..., op. cit., p. 115. 
consciente de sí misma "como de su mundo y del mundo como de sí misma" ¿cómo se da esto? Ya lo hemos revisado en la figura (Gestalt) del Espíritu objetivo cuando aparece la sociedad civil, la familia, el Estado y finalmente se da el paso hacia el Espíritu absoluto.

El estar con el otro representa una situación compleja pero necesaria. El itinerario que el espíritu inicia desde la certeza sensible, donde el individuo se percibe a sí pero incapaz de reflexionar por lo que no logra aprehenderse a sí mismo como conciencia y mucho menos a otras conciencias. Aun así, continúa el camino hacia las formas objetivas, eticidad para converger en la figura del Espíritu absoluto, arte, religión y filosofía que representan para el individuo en cada una de estas figuras, una real configuración.

A través de las etapas, Hegel se propone mostrar el continuo proceso de la liberación del individuo en dos momentos esenciales. En primer lugar, la autonomía en relación con la vida trabajada, afanada, y finalmente reconociendo la independencia del otro enmarcado en una comunidad de hombres libres ${ }^{176}$. Así, la autoconciencia al despertar el entendimiento que sólo era en sí concluirá al cabo de su desarrollo siendo en sí y para sí. Sólo al finalizar el enfrentamiento entre las autoconciencias es que logra convertirse en razón. Lo dicho hasta aquí supone, que esa autoconciencia, retomando la cuestión del amo y el esclavo, encuentra en su devenir esa formación que sólo lo convierte en una autoconciencia universal. Se dará cuenta de la intersubjetividad presente en sí mismo y por consiguiente en los demás,

175 Ibíd., p. 259.

176 Ibíd., p. 202. 
esto ya lo había asomado Hegel en El amor y la propiedad, escrito del periodo de Frankfurt. En torno a esto apuntará que partiendo "de la unión no-desarrollada, la vida ha recorrido, a través de su [proceso de] formación, el ciclo completo hasta la unión completa"177. Ese es el ciclo que lo lleva a completar su odisea hacia lo Absoluto y que por cierto ya asomaba desde sus escritos juveniles en el Seminario de Tubinga donde realizó sus estudios universitarios de filosofía y teología.

En este escenario podemos señalar que en Hegel la continua consecución de la conciencia y su respectiva constitución de la formación del individuo a través de la “cultura (Bildung) y formación o disciplina cívica (Zucht); eso representa talentos, descubrimientos, ciencia, de un modo formal. Lo que es real es el Todo, lo absolutamente universal, lo que se mueve en sí dentro del pueblo"178. En este momento parece sensato dar el punto vista expuesto por nuestro autor: un sujeto formado es que ya ha sido transformado en la sociedad civil (Zivilgesellschaft) bajo la figura de la Eticidad con características propias ganadas mediante el trayecto tortuoso que ha realizado a través de las etapas de formación del Espíritu universal (Universeller Geist).

Ahora bien, todo lo dicho hasta aquí refuerza nuestra comprensión sobre el pensamiento hegeliano respecto a Bildung. Sin embargo, resulta conveniente aclarar más este asunto, aunque ya hemos tocado la idea de Eticidad volvamos a ella para poder explicar la cuestión del Espíritu objetivo en este contexto. Creemos

177 Hegel, G.W.F., Escritos de juventud, Trad. Zoltan Szankay y José María Ripalda, México, Fondo de Cultura Económica, 1989, p. 262. Recomendamos leer nota a pie de página.

178 Hegel, G.W.F., El sistema de la Eticidad, Trad. Luis González-Hontoria, Madrid, Editora Nacional, 1982, p. 192. 
conveniente revisarla aquí, así sea brevemente, ya que es axial en el pensamiento del filósofo de Stuttgart y, por consiguiente, veremos que tiene implicación en su idea de formación.

Hegel sostendrá que "la eticidad absoluta es asimismo la educación absoluta (Bildung), pues en lo eterno se encuentra el aniquilamiento real empírico de todas las determineidades, así como el cambio de todas las determineidades" ${ }^{179}$. Observamos que, en la Bildung, es donde logra concretarse el Espíritu objetivo, en el cual alcanza a incorporarse y establecerse en la vida ética de un pueblo. Sin embargo, Hegel continúa su exposición con una cuestión un tanto compleja. Partamos de lo que nos dice el propio autor: "la educación (Bildung) es esta absoluta alternancia dentro del concepto absoluto, donde cada sujeto, a la vez que lo universal, transforma su particularidad de un modo inmediato en universalidad concreta" ${ }^{\text {180 }}$. Con este fragmento, nos percatamos que en Hegel es evidente la idea de que la formación logra una fuerza capaz de convertir su mundo y llevarlo desde su en sí a un para sí.

Nos queda otra cuestión que abordar, la Autoconciencia y vida (Selbstbewusstsein und Leben). El proceso de formación se subsume bajo estas dos cuestiones por ser un complejo dar con el otro como reconocimiento en sí y para sí. Lo más relevante de este momento sobre la exposición de la conciencia, es que la verdad de la conciencia es la autoconciencia ${ }^{181}$, es decir, es saber de sí en tanto otro que está en frente. La autoconciencia lucha con otras autoconciencias que no es más

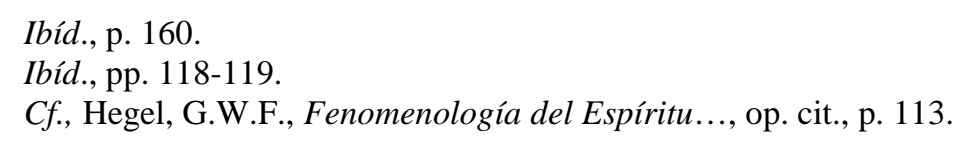


que el reconocimiento del otro y de querer ser reconocido, en eso consiste la vida con todas las implicaciones que va generando. Cuando se penetra en el interior de la vida es el viviente quien siente y en tal sentido es el sujeto de la conciencia en tanto que sí mismo.

De acuerdo con nuestra investigación hemos revisado cómo se hace el esperado tránsito desde la conciencia a la autoconciencia y vida y cómo es posible que el entendimiento penetre la cosa, es decir, en el interior de la cosa y la piense, es lo viviente a quien corresponde saber y en esa medida es también saber de sí. A juicio de C. Másmela refiriéndose a esto, apunta lo siguiente "la autoconciencia es la conciencia provista de sí mismo. El sí mismo introduce la reflexión en el saberse a sí misma de la autoconciencia. Pero esta reflexión se lleva a cabo en su retornar «desde el ser otro» ${ }^{" 182}$. Sin embargo, este recorrido tiene sus momentos como lo son la autoconciencia en sí, la vida, el yo y la apetencia.

En las figuras de la Fenomenología del Espíritu pudimos observar que la conciencia había entrado en una profunda incertidumbre de creer ser la verdad y al mismo tiempo abrazado con el pensamiento de que la verdad fue necesariamente eso por lo cual preguntaba que era el objeto, es decir, que lo que es ser-para-sí lo es asimismo ser-para-otro; de una forma u otra es lo mismo. Con todo es Hegel el que nos da la clave: "llamamos concepto a lo que el objeto es en sí y objeto a lo que es

182 Másmela, C., Hegel: La desgraciada reconciliación del espíritu. Madrid, Editorial Trotta, S. A., 2001, p. 24. Cursiva en el texto-fuente. 
como objeto o para otro, vemos que es lo mismo el ser en sí y el ser para otro, pues el en sí es la conciencia" ${ }^{, 183}$.

El relacionarse implica lo reflexionado como cosa enunciada, como algo que posee por sí la misma certeza que tiene la reflexión de la autoconciencia. Estamos ante lo que Gadamer, al comentar a Hegel, afirma “[é]sta es la verdadera penetración en el interior de la naturaleza, la única que es capaz de captar la naturalidad de la misma, o sea, su vida: lo viviente siente lo viviente" ${ }^{\text {"184 }}$. Esta afirmación del filósofo de Marburgo tiene suficiente sustento al entender lo que «es de sí mismo» que no es más que conocerse a sí mismo, como sí mismo en tanto otro, por lo cual lo lleva a ser autoconciencia y vida.

La autoconciencia regresa a sí misma enfrentando el problema del otro, es precisamente el objeto que tengo enfrente en el mundo sensible e independiente. La independencia negada es lo que se tiene delante que es distinto; lo que niega es el objeto como tal de la negación de mi yo. Esto es muy diferente a lo dicho por Fichte que lo plantea de esta forma: Yo = Yo. Con razón, Hegel cuestionará que el "fundamento del sistema de Fichte es la intuición intelectual, pensar puro de sí mismo, autoconciencia pura, Yo = Yo, Yo soy; lo absoluto es sujeto-objeto, y el Yo es la identidad de sujeto y objeto" ${ }^{185}$. Es cuanto al compartir, el «yo» fichteano está en lo cierto de sí en tanto esté el otro enfrente en igual 'soledad'.

\footnotetext{
Hegel, G.W.F., Fenomenología del Espíritu..., op. cit., p. 107. Cursivas de Hegel.

184 Gadamer, H-G., La Dialéctica de Hegel. Trad. Manuel Garrido, Madrid, Editorial Cátedra, 1994, p. 74.

185 Hegel, G.W.F., Diferencia entre los sistemas de la filosofía de Fichte y Schelling. Trad. $\mathrm{M}^{\mathrm{a}}$ del Carmen Paredes Martín, Madrid, Editorial Tecnos, 1990, p. 57. Cursivas del autor.
} 
No hay dudas que la alteridad nos permite saber de sí en tanto lo que tengo frente a mí, es la negatividad lo que permite ese ir reflexivo y su regreso, la autoconciencia consigue su satisfacción solo en otra autoconciencia ${ }^{186}$. En palabras de Martínez Mazoa: "el objeto (la infinitud, lo otro que, sin embargo, no es otro) afirma su independencia, la infinitud como objeto para la conciencia es la vida, el movimiento de suprimir las diferencias" ${ }^{\prime 187}$.

Todo esto se da porque la conciencia de sí (autoconciencia) está consciente de la negación del otro que está enfrente afirmando el yo como la verdad. Cuando una autoconciencia ve enfrente al otro es esa reflexión de la negación del otro lo que hace afirmar lo otro de sí mismo. Para afirmar más esta idea apelamos a Martínez Mazoa que nos explica que "la conciencia de sí en su propia relación negativa a lo otro, no suprime lo otro, no hace más que afirmarlo precisamente como otro; luego la conciencia solo puede ser absolutamente conciencia de sí misma" ${ }^{\text {"188. }}$.

El saber de sí, no se conforma con el saber del objeto, la autoconciencia necesita ser en sí y para sí, es decir, la autoconciencia sólo estará satisfecha en cuanto es para otra autoconciencia porque quiere ser reconocida por otra autoconciencia. Es en esto que consiste la vida porque estando cada autoconciencia cierta de sí misma, ésta demanda ser reconocida por otra autoconciencia y es allí donde comienza el conflicto.

Cf., Hegel, G.W.F., Fenomenología del Espíritu..., op. cit., p. 112.

187 Martínez, F., Historia de la Filosofía, Madrid, Ediciones Istmo, 1973, p. 290. Cursivas del autor.

188 Ibídem. 
Cada una de estas autoconciencias aborrece su vida y también la de otra autoconciencia, sin embargo esta experiencia, esta lucha entre las autoconciencias, le es esencial la vida ya que sin la vida ésta no puede ser negada. Palmier afirma que la “conciencia de sí que es deseo no podrá descubrir la verdad más que en otra conciencia, que sea tan viviente como ella"189. A propósito de la conflictividad que se da en la dialéctica del amo y el esclavo, Marx más tarde la utilizará, con su extraordinario genio, al desarrollar la lucha de clases donde piensa él que está el motor de la historia.

El Deseo por una cosa atractiva que tenemos al frente, ya que forma parte de lo viviente que vive solo para desear es, utilizando a Nancy, temblar "con el temblor de lo otro [como] el sí-mismo llega en el deseo. La conciencia de sí es esencialmente deseo, porque es conciencia de sí en cuanto que y a partir de su conciencia de lo otro ${ }^{190}$. Lo verdadero es alcanzado por lo deseado que ha recorrido la conciencia para llegar al sí mismo y continuamente va engendrando cada vez más deseos.

Heidegger apunta que "el hacia-sí, el cual pertenece al ser-en-el-interior-de-sí del sí-mismo, el retorno a sí como verdad, es aprehendido como deseo, como el afán del sí-mismo por él mismo"191. Pero en realidad no se está refiriendo al deseo de un objeto como tal, sino más bien que el deseo nos es dado por el deseo de una conciencia igual a la nuestra. En otros términos, el "deseo es deseo del sujeto, y no

Palmier, J., Hegel..., op. cit., p. 43.

190 Nancy, J., Hegel. La inquietud de lo negativo, Trad. Juan Manuel Garrido, Madrid, Arena Libros S. L., 2005, p. 68. Cursiva del autor.

191 Heidegger, M., La Fenomenología del..., op. cit., p. 198. Cursivas del autor. 
hay objeto del deseo"192 . Comienza entonces el problema o más bien la guerra por el reconocimiento del otro que se da en la dialéctica del amo y el esclavo, que analizamos más arriba.

Es importante señalar aquí que en un principio el hombre es deseoso de los objetos que le rodean pero no tardara en darse cuenta como señala Marcuse que "llega a sentir que los objetos no son el fin verdadero de su deseo, y que sus necesidades sólo pueden satisfacerse a través de la asociación con otros individuos" ${ }^{193}$. La vida, se va generando desde dentro de sí y como asevera Heidegger la "unidad es «la quietud de sí misma como infinitud absolutamente inquieta». El ser es aprehendido como la autonomía, el constante ser-sí-mismo que se mantiene en el interior de sî́,194.

Por otro lado, Hegel en sus escritos de juventud hacía referencia a la vida pero no en los términos tan complejos o imbricados de la Fenomenología del Espíritu. En sus mocedades pensaba más en religión que en filosofía y en sus pensamientos comenzaba a brotar o hacer eclosión en él lo que más tarde sería todo su sistema filosófico y prueba de ello está en su Fragmento de Sistema de Frankfurt donde ya comienza asomar el problema de la vida pero como tema teológico. Estas son sus palabras: "si el hombre pone simultáneamente la vida infinita como espíritu del otro

Nancy, J., Hegel. La inquietud..., op. cit., p. 69.

93 Marcuse, H., Razón y Revolución. Hegel y el surgimiento de la teoría social, Trad. Julieta Fombona de Sucre y Francisco Rubio Llorente, Madrid, Alianza Editorial, 1976, p. 116.

194 Heidegger, M., La Fenomenología del..., op. cit., p. 205. Cursivas del autor. 
fuera de sí [...] y a sí mismo fuera de sí, fuera de lo limitado, elevándose hacia lo viviente y unificándose íntimamente con él, entonces adora a Dios" ${ }^{\text {195 }}$.

El pensamiento hegeliano más trabajado se encuentra en sus escritos posteriores y uno de los que más resaltan es, sin duda, la Fenomenología del Espíritu, donde plantea la vida en otros términos. Nuestro filósofo, específicamente, no se refiere a la vida en general sino a la vida del ser humano como tal, enmarcada en una historia y concreta en usos y costumbres. Comienza el autor de la Fenomenología a observar que se debe abandonar el pensamiento que ha llevado a la autoconciencia aislada es decir, superar la conciencia en sí. Hyppolite lo plantea de la siguiente manera "es esta separación del todo y de las partes, al mismo tiempo que su separación, lo que constituye la infinitud, la vida universal como «vínculo del vínculo y del no vínculo»"196.

Pero qué significa identidad de la identidad y la no identidad. Pongamos por caso al $\left(\mathrm{Yo}_{\mathrm{o}}=\mathrm{Yo}\right)$ de Fichte que contradice lo expuesto por Hyppolite. Aquél, propone la negación, el «no Yo» y así el yo soy es igual a yo soy, en tanto autoconciencia pura. En cambio en Hegel se diría así: sé que soy yo porque existe un yo diferente, un No-YO que permite que sepa quién soy, (Yo = Yo y no-Yo). El filósofo francés expresa que: "este movimiento considerado en sí mismo, constituye «la vida universal, el alma del mundo», pero sólo es para sí en la autoconciencia

195 Hegel, G.W.F., Escritos de juventud..., op. cit., p. 401.

196 Hyppolite, J., Génesis y Estructura de la Fenomenología del Espíritu de Hegel. Trad. Francisco Fernández Buey, Barcelona, Ediciones Península, 1974. p. 135. 
humana como conciencia de esta vida" ${ }^{\text {197 }}$. Esta negación que permite reconocer al otro y que forma parte de su genio y que además va concretándose a través de sus obras permite concluir lo que él llama «la vida universal, el alma del mundo».

Ahora bien, el conjunto de reflexiones que hemos hecho hasta aquí y que articulan, como hemos visto, la noción de formación en Hegel tiene sus extensiones teóricas en el pensamiento de Gadamer, autor que será objeto de estudio en el próximo capítulo. Nos corresponde exponer la pertinencia y actualidad ético-política de la Bildung gadameriana en la praxis humana de la sociedad actual.

197 Ídem. 


\section{CAPÍTULO III}

\section{LA BILDUNG EN LA HERMENÉUTICA DE GADAMER: ORIGINALIDAD Y REPERCUSIÓN SOCIAL}

\subsection{Fuentes de la concepción gadameriana de formación}

Hemos de comenzar este capítulo señalando que Gadamer es un fiel representante de la cultura alemana en cuanto a la dilatada resonancia de la Bildung o formación del ser humano en una sociedad. Se nutrió de todos aquellos aspectos teóricos y de aplicación que hacen posible que el hombre desarrolle todas sus potencialidades dentro de una comunidad específica pero con espíritu universal. Dos fueron sus convicciones sobre el proceso formativo que orientaron su hermenéutica filosófica: es ineludible formarse para actuar con tino ético e incidir políticamente dentro de una comunidad y, el humano cuenta tanto con las cualidades (razón, lenguaje, voluntad) como con las herramientas necesarias (educación, modelos e historia) para constituir armoniosamente su humanidad y fortalecer el bien común.

Dentro de las diferentes fuentes a las que apeló Gadamer para desplegar su proyecto hermenéutico se encuentra la de Herder, que desarrollamos en el primer capítulo. Tomó de este pensador alemán el concepto de formación como cultura que se sustenta en un «Ascenso a la humanidad» (Beförderung zur Menschheit). Esto significa que dadas las disposiciones y capacidades naturales del hombre -que es una parte de sus condiciones- éste necesita, para su integral desarrollo, de una 
formación ${ }^{198}$ que se sustenta, fundamentalmente, en el lenguaje (Sprache). Para el filósofo de Mohrungen cada lengua es un principio genético vivo con el que los miembros de un pueblo realizan su vida espiritual y social, con sentido o con orientación general para el logro de objetivos comunes.

Desde estas ideas herderianas, Gadamer destaca que el "lenguaje no es sólo una de las dotaciones de que está pertrechado el hombre tal como está en el mundo, sino que en él se basa y se representa el que los hombres simplemente tengan mundo" ${ }^{\text {"199. }}$. Al profundizar, sobre la génesis de este don humano de comunicación y alcanzar en lo más recóndito y profundo de su sentido germano, intenta dar con su fundamento original y estimulante. Esto se aprecia claramente cuando apunta que desde Herder "el pensamiento moderno sobre el lenguaje está dominado por un interés muy distinto" ${ }^{, 200}$, vale decir, un interés en el que se da la bienvenida a los problemas lingüísticos y a las ciencias del lenguaje, en sus implicaciones éticas, sociales y cognitivas.

Lo que le interesa a Gadamer, en definitiva, es que Herder le ha dado a la noción de Bildung una acepción que implica sustancialmente una atmosfera natural e histórica en la que se desplegarán las virtualidades del ser humano. La filosofía e intención herderianas están dirigidas claramente a potenciar lo humano mediante el uso acertado del lenguaje, la razón, la libertad, la cultura y, finalmente, la religión como fondo sustentador. Lo que se propuso fue alcanzar "la más elevada humanidad

\footnotetext{
Cf., Gadamer, H-G., Verdad y Método I..., op. cit., pp. 38-48.

Ibíd., p. 531. Cursivas del autor.

Ibíd., p. 526.
} 
de hombre"201. Lo cierto de todo esto es, según Gadamer, que el filósofo de Mohrungen le ha permitido ver, cómo la formación es uno de los conceptos fundamentales de la tradición humanística que le sirve para su propósito de llevar su ideal: un ser dialógico, libre, solidario y abierto a múltiples horizontes.

El otro pensador contemporáneo con Herder al que recurre Gadamer para perfilar su hermenéutica es Humboldt. De éste tomará el pensamiento de que debe existir una estrecha relación entre el lenguaje, el mundo y el hombre para que se pueda hablar de un verdadero y factible proceso formativo. También heredará “de la línea humboldtiana, entre otras cosas, el rechazo del lenguaje como instrumento y como objeto",202.

Para Gadamer, el filósofo de Potsdam "reconoció la esencia del lenguaje en la realización viva del hablar, en la enérgeia lingüística, rompiendo así con el dogmatismo de los gramáticos”203. El lenguaje está inmanente al hombre tal como él se encuentra en el mundo y su existencia, a la vez, "está constituida lingüísticamente" ${ }^{204}$. Un dinamismo dialéctico y formativo que supone un compartir desde la diversidad. Dicho de otra manera, el lenguaje, más sapiente, cognitivo e interior, transforma al hombre en todos los aspectos de su vida, en su estar en el mundo con los otros. Humboldt nos sintetizará lo que entiende por Bildung: “cuando en nuestra lengua decimos «formación» nos referimos a algo más elevado y más

Herder, J., Ideas para una..., op. cit., p. 124.

Crelier, A., Introducción a la..., op. cit., p. 137.

Gadamer, H-G., Verdad y Método I..., op. cit., p. 531.

Ibídem. 
interior, al modo de percibir que procede del conocimiento y del sentimiento de toda la vida ética y se derrama armoniosamente sobre la sensibilidad y el carácter"205.

El tema del lenguaje ha sido para Gadamer representativo en el sentido ético e histórico del término pues el "lenguaje, no es la huella de la finitud porque exista la diversidad de la estructura del lenguaje humano, sino porque cada lengua se forma y prosigue continuamente al paso que va trayendo al lenguaje su propia experiencia del mundo"206. Lo que esto significa es que para el pensador de Marburgo la experiencia hermenéutica de la lengua expresa el mundo en lo particular como un elevarse libremente del «entorno» en el que sólo se vive ${ }^{207}$.

El último filósofo al que Gadamer hace referencia, de manera profusa, es Hegel. Se podría decir que es su icono principal para sustentar su noción de Bildung. Lo ha reseñado fundamentalmente para comprender el trayecto que recorre la consciencia a través de las figuras del Espíritu aunque no lo acompañó, en la conclusión de que "la formación como movimiento de enajenación y apropiación se lleva a término en un perfecto dominio de la sustancia, en la disolución de todo ser objetivo que sólo se alcanza en el saber absoluto de la filosofía" ${ }^{208}$. Para Hegel, el sujeto se consume en el saber Absoluto, en la totalidad o, dicho de otra forma, le carga todo el proceso al Espíritu absoluto que lo absorbe todo. Según el autor de Verdad y método, a diferencia de la concepción hegeliana, el hombre en su finitud tiene una apertura a nuevas experiencias en la medida que éstas lo lleven a una

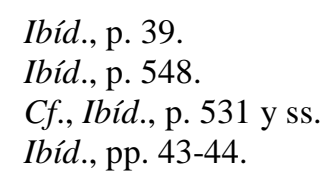


reflexión o a un saber de sí mismo. Lo importante es que a través de la finitud, los hombres hacen historia ${ }^{209}$ y se forman en un proceso no controlado, es decir, que no concluye en un saber Absoluto como dirá Almarza "todas las expectativas y proyectos de comprensión de los seres finitos son finitos: La experiencia es siempre experiencia de la finitud humana" ${ }^{210}$.

No obstante las dificultades teóricas, Gadamer reconoce que Hegel ha sido fundamental para poder explicar la noción de formación porque ha sido el punto de quiebre en contra de la inmediatez del ser natural y la afirmación del «ascenso a lo universal», esto es, la "esencia general de la formación humana es convertirse en un ser espiritual general"211. Aunado a los presupuestos teóricos anteriores, Gadamer igualmente radicaliza ética y políticamente el punto cardinal hegeliano de que "la formación significa poder contemplar las cosas desde la posición de otro"212.

Bajo las improntas teóricas de estos tres filósofos, Gadamer tiene el propósito de llevar su pensamiento hacia un horizonte más vasto que le permita enfatizar la importancia que tiene la hermenéutica filosófica en el quehacer del hombre o más específicamente, investigar "aquellas esferas del compromiso humano en que es

209 Es verdad que para Hegel la historia forma parte fundamental en su pensamiento filosófico, sin embargo, en el contexto en el cual estamos desarrollando la idea de Gadamer estamos en la obligación de expresar lo que este filósofo quiere explicar sobre la finitud histórica de los hombres más allá del historicismo hegeliano.

210 Dieter, K. y Almarza, J., (Coord), "El pensamiento alemán contemporáneo, Hermenéutica y teoría crítica", en Almarza, J., H.G. Gadamer: La historicidad de la comprensión. Fundamentos para una teoría de la experiencia hermenéutica, Salamanca, Editorial San Esteban, 1985, p. 38.

211 Gadamer, H-G., Verdad y Método I..., op. cit., p. 40.

212 Koselleck, R. y Gadamer, H-G., Historia y Hermenéutica..., op. cit., p. 125. 
fundamental la actividad del entendimiento y la interpretación" ${ }^{213}$ dentro de una praxis social compartida. Así, plantea que el campo de la hermenéutica es mucho más amplio puesto que no sólo se circunscribe al tradicional ámbito de la teología y la jurisprudencia, sino que abarca un amplio espectro ${ }^{214}$ de saber, hacer e interpretar.

El logro de esta perspectiva de largo aliento tiene sus obstáculos. Gadamer en su obra cumbre Verdad y Método, escrita en 1960, pone sobre el tapete las dificultades de las humanidades. Esto lo lleva a enrumbarse resueltamente en la polémica que gira en torno a la cuestión del método para luego reflexionar sobre la verdad de las ciencias del espíritu basada en una creación hermenéutica no necesariamente metodológica.

En torno a la controversia de la metodología entre las ciencias naturales y las ciencias del espíritu, Gadamer estableció sus diferencias (Verschiedenheit). Hizo un estudio histórico-semántico general para caracterizar conceptualmente ambas posiciones aunque con la pretensión de trascender la disputa metodológica. De acuerdo con su óptica, los "métodos de la ciencia natural no captan todo lo que vale la pena saber, ni siquiera lo que más vale la pena" ${ }^{215}$. Además de tener un campo restringido en cuanto a la dinámica humana: lo observable, lo medible, lo controlable y lo repetible. Parten de que se debe establecer una 'distancia' entre sujeto y objeto para poder lograr la objetividad y se orientan, en muchos casos, por un espíritu de dominación. En cambio, en las ciencias del espíritu "el fenómeno de la comprensión

213 Beiner, R., El juicio político, Trad. Juan José Utrilla, México, Fondo de Cultura Económica 1987, p. 47. Ibídem.

Gadamer, H-G., Verdad y Método II..., op. cit., p. 43. 
no sólo atraviesa todas las referencias humanas al mundo, sino que también tiene validez propia dentro de la ciencia, y se resiste a cualquier intento de transformarlo en un método científico"216. Desde las ciencias humanas se puede alcanzar una comprensión que exprese verdades que no necesariamente sean 'verificables' como se hace en las ciencias naturales.

El punto es que Gadamer critica, esencialmente, la relevancia que se le ha dado a la idea de una metodología científica como única vía o alternativa para alcanzar la verdad, pues según piensa está lejos de ser la única opción, lo cual permite ver el problema desde otra óptica. Por eso nos advierte que en "realidad las ciencias del espíritu están muy lejos de sentirse simplemente inferiores a las ciencias naturales" 217 .

El problema sigue siendo, nos dirá Gadamer, que la “autorreflexión lógica de las ciencias del espíritu, que en el siglo XIX acompaña a su configuración y desarrollo, está dominada enteramente por el modelo de las ciencias naturales"218 ${ }^{\text {. Por }}$ tal motivo, el reto es lograr que las ciencias del espíritu de la tradición humanística rompan el cerco del baremo científico que las sujeta en su pretensión de explicar el desarrollo de la formación del hombre en una sociedad. Para lograr este cometido había que dar un nuevo y audaz viraje.

En el paso de transición Gadamer se apoya en tres pensadores que se caracterizan por encontrarse entre la ciencia, la historia y la filosofía. Estos

Gadamer, H-G., Verdad y Método I..., op. cit., p. 23. Cursivas de Gadamer.

Ibíd., p. 37.

Ibíd., p. 31. 
consiguieron abrirle el itinerario hacia su hermenéutica filosófica u ontológica enmarcada dentro del mundo socio-histórico ${ }^{219}$. Ellos son H. Helmholtz, J.G. Droysen y W. Dilthey. Veamos brevemente sus aportes. El primero de estos autores, que es un especialista en ciencias naturales, entendía que la forma específica de trabajar de las ciencias del espíritu se encuentra en la memoria y en una fina sensibilidad o tacto (takt) artístico $^{220}$. Aunque en una "primera mirada [se revelan] como poco aptos para un control intersubjetivo" ${ }^{\text {221, }}$, el reconocimiento de su importancia significó un gran paso por cuanto la hermenéutica no queda confinada a reglas fijas o a dinámicas metodológicas; son, más bien, elementos fundamentales de formación dentro de una especial psicología humana.

Por su parte, Droysen sostiene que el hecho de que se invoquen los logros, avances o relevancia del modelo científico no "implica que las ciencias del espíritu

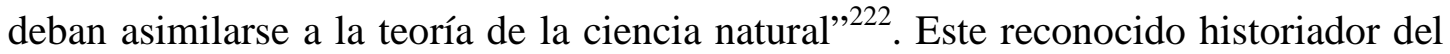
siglo XIX y perteneciente a la escuela histórica, llama poderosamente la atención sobre la idea de que tiene que ser plausible una investigación basada en el método histórico aplicado a las ciencias de la naturaleza, si realmente la historiografía es como se dice una cuestión de investigar y nada más que investigar. La razón es que a "la investigación le conviene una infinitud distinta y cualitativa cuando lo investigado no ha de poder ser nunca contemplado por sí mismo"223. Obviamente que esto supone

Cf., Ibid., p. 32.

Cf., Ibíd., p. 44.

Karczmarczyk, P., Gadamer: aplicación y comprensión, Buenos Aires, Editorial de la Universidad Nacional de la Plata, 2007, p. 67.

222 Gadamer, H-G., Verdad y Método I..., op. cit., p. 34.

223 Ibíd., p. 274. 
un valor trascendente del pasado histórico. En definitiva, la contribución de Droysen, así lo resalta Gadamer, es dar cuenta de la tradición pero siempre pensando en un eterno preguntar, al mejor estilo de la mayéutica socrática.

En el caso de Dilthey, a quien Gadamer dedicó tiempo en su indagación, habría que decir que bajo la ascendencia del pensador inglés John Stuart Mill se dejó “influir muy ampliamente por el método de las ciencias naturales, a pesar de su empeño en justificar la autonomía metódica de las ciencias del espíritu"224. Así, desde una perspectiva historicista, una psicología comprensiva y la autorreflexión, se propuso dar una "base fundacional de las ciencias del espíritu anclada en las ciencias de la naturaleza, procurando, eso sí, suministrar a aquellas un estatus epistemológico totalmente independiente aunque comparable a estas en condición de objetividad"225.

Trató de compaginar la expresión, la comprensión y la vivencia en un camino del exterior al interior o en un vivenciar retrospectivo. Pero más allá de si Dilthey logró o no una autonomía epistemológica de las ciencias del espíritu, lo importante es enfatizar el esfuerzo teórico que llevó adelante y suscribir que sus obras constituyen "la toma de conciencia determinante del conjunto de la cuestión de las ciencias humanas con sus implicaciones filosóficas, lógicas y epistemológicas"226. Es precisamente desde este camino andado, que Gadamer pudo decir que no existe, propiamente hablando un "método propio de las ciencias del espíritu"227, sino que las

Ibíd., p. 35.

Cf. Recas, J., Hacia una hermenéutica crítica, Gadamer, Habermas, Apel, Vattimo, Rorty, Derrida y Ricoeur, Madrid, Biblioteca Nueva, 2006, p. 105.

226 Freund, J., Las teorías de las ciencias humanas, Barcelona, Ediciones Península, 1993, p. 79.

227 Gadamer, H-G., Verdad y Método I..., op. cit., p. 36. 
ciencias del espíritu son "formas de experiencias en las que se expresa una verdad que no puede ser verificada con los medios que dispone la metodología científica"228.

Ahora bien, después de este sucinto recorrido por todos aquellos pensadores que son de una importancia determinante en la hermenéutica filosófica de Gadamer, entramos a presentar el punto de vista de este autor para desentrañar su novedoso y complejo entramado conceptual relacionado con la Bildung o formación. Los conceptos que vamos a analizar están enmarcados dentro de la «tradición humanística» y nos van a permitir comprender el itinerario que transita el filósofo alemán para darle forma a su pensamiento hermenéutico.

\subsection{La tradición humanística: más allá de la voluntad metodológica}

Es importante que comencemos por señalar que la «tradición humanística» gadameriana está enmarcada en una reivindicación de la experiencia filosófica de la «verdad»y de la búsqueda de la unicidad de la función artística a partir de una reflexión crítica de la estética moderna ${ }^{229}$. Así Gadamer se propone la superación, a través del «juego», de la dimensión del arte en su exclusivismo sensible o subjetivista. Es dentro de esta indagación que el autor "comienza exponiendo la «significación humanística para las ciencias del espíritu»" ${ }^{\text {,30 }}$. La preocupación del filósofo apunta esencialmente en poder darle un giro a la cuestión del método y aplicar dentro de las

Ibíd., p. 24. Las cursivas son del autor.

229 La concepción estética de Gadamer no forma parte de los objetivos de este trabajo debido a su complejidad o entramado conceptual. Con todo, puede consultarse la obra de este filósofo que lleva por título: La actualidad de lo bello, Trad. Rafael Argullol, Barcelona, Ediciones Paidós Ibérica, 2002.

230 Conill, J., Ética hermenéutica. Crítica desde la facticidad, Madrid, Editorial Tecnos, 2010, p. 61. 
ciencias humanas o la tradicional humaniora la noción de formación, a través de lo que nuestro autor llama «conceptos básicos del humanismo».

Entonces, la pregunta que viene al caso es ¿cómo el filósofo aborda la formación del hombre como ideal ético-político dentro de la tradición humanística? Podríamos responder en un principio a esta pregunta señalando que el "legado humanista que Gadamer expresamente moviliza no está referido al modelo renacentista latinizante" ${ }^{\text {231 }}$ antiescolático e interesado en actualizar los valores culturales del mundo griego. Alude, más bien, a un conjunto de términos que han emanado del humanismo alemán y que tienen como punto de partida el siglo XVIII y que llega hasta principios del siglo XIX.

Los conceptos del humanismo ${ }^{232}$ a los que apela Gadamer se rigen por una categoría de verdad -como sentido y experiencia- que se explica desde las ciencias del espíritu sin necesidad de recurrir a criterios científicos. Además, los rasgos distintivos de dichos términos humanísticos no tienen "como perspectiva primera producir resultados objetivables y mesurables"233 garantizados por la distancia adecuada entre un sujeto y el objeto de su investigación. Desde estas premisas fundamentales, el filósofo tendrá la certidumbre de que no sólo en las ciencias naturales se encuentra, bajo la égida metodológica, el «conocimiento, la verdad y el logro» sino que también existen otros caminos válidos y dilatados para llegar a ellos,

231 Gutiérrez, C., Ensayos hermenéuticos, México, Ediciones Siglo XXI, 2008, p. 82.

232 Grondin sintetiza el paso teórico gadameriano a la tradición humanística: "en lugar de seguir ciegamente [la] metodología [científica], por lo demás poco conforme con su práctica real, [optó por] las ciencias humanas [que se inspiran] en la tradición algo olvidada del humanismo, de donde además toman su nombre las ciencias humanas (humaniora) (Grondin, J., ¿Qué es la hermenéutica?, Trad. Antoni Martínez Riu, Barcelona, Editorial Herder, 2008, p. 72).

233 Ibídem. 
sin renunciar a aquellos aspectos de proyección humana no cuantificables u observables $^{234}$.

Fiel a sus presupuestos, el autor de Verdad y método actualizará creativamente los vocablos de la tradición humanística alemana para dar cuenta al final de cómo se fusionan, en un todo, con la Bildung. Sin embargo, precisa el lugar que cada uno tiene en el ámbito de su hermenéutica filosófica y cuáles son las consecuencias que se desvelan de sus características específicas. Nosotros, para transitar su pensamiento al respecto, seguiremos este orden: Bildung o formación, sensus communis, la capacidad de juicio y el gusto.

Como hemos mostrado en los dos capítulos anteriores, el concepto de Bildung adquirió una preponderante validez y "fue sin duda el más grande pensamiento del siglo XVIII, y [el concepto] que designa el elemento en el que viven las ciencias del espíritu en el XIX” ${ }^{235}$. En términos de una filosofía práctica, canaliza la concepción hermenéutica de Gadamer y su novedosa manera de comprender y cuestionar el mundo que le tocó vivir.

El vocablo de Bildung tiene, en Gadamer, varios significados dependiendo del contexto y la evolución de su pensamiento. Así, lo utiliza en la acepción de formación, cultura o educación, tal como en la vida cotidiana o académica se habla

${ }^{234}$ Clara Ríos comenta que a partir del reconocimiento del método de las ciencias naturales es imposible enfrentar, adecuadamente, los problemas que pertenecen a las ciencias del espíritu: el ético-axiológico y el social. De tal manera que se hace difícil explicar la naturaleza humana desde una rigurosidad metodológica que trata sobre la exactitud de los enunciados presentados. En otros términos, la "diferencia en el método resulta determinada por la singularidad del objeto en su relación particular con las leyes que pretenden ser comprendidas". (Ríos, C., "Un acercamiento al concepto de formación en Gadamer", en Revista de Educación y pedagogía, № 15-16, Medellín, 1995, p. 17).

235 Gadamer, H-G., Verdad y Método I..., op. cit., p. 37. 
"del ciudadano culto (Bildungsbürger), de los tiempos de cultura superior",236. Aun cuando esto sea cierto, tenemos que decir que el filósofo alemán hace ciertas aclaraciones al respecto. Considera que es 'bastante dudoso y funesto' que se hable de clases incultas y cultas por una "exagerada «patente» de cualidades académicas" ${ }^{237}$. Además, sostiene que el término Bildung, aunque en el idioma alemán esté sujeto al significado de enseñanza, no consiste en una erudición acumulativa de conocimientos varios, de teorías especializadas y métodos. Nos aclarará que un proceso formativo no se puede circunscribir a un resultado específico de un saber instrumental o a una meta intelectual alcanzada de forma acabada.

Para Gadamer, la Bildung es, ante todo, un proceso que nunca termina porque es una permanente e irrenunciable tarea de perfeccionamiento y universalización propia del ser humano. Insistirá en que no debemos "olvidar jamás que nos educamos a nosotros mismos” ${ }^{238}$. La preocupación por sí mismo es una responsabilidad intransferible pero, igualmente, un individuo debe aprender a ir más allá de su particularidad o deseos inmediatos y orientar su vida en "favor de la generalidad"239. En virtud de este ascenso logra ser libre, es decir, elevar su condición humana tomando en cuenta todas sus propensiones virtuales y los frutos sociales que emanan del arduo trayecto de la tradición y que se sintetizan en el «sentido común». Se trata

\footnotetext{
${ }^{236}$ Koselleck, R. y Gadamer, H-G., Historia y Hermenéutica..., op. cit., p. 124.

Ibídem.

238 Gadamer, H-G., La Educación es Educarse, Trad. Francesc Pereña Blasi, Barcelona, Ediciones Paidós Ibérica, S.A., 2000, p. 15.

239 Hegel, G.W.F., Fenomenología del Espíritu..., op. cit., p. 209.
} 
de un amplio desarrollo cultural por cuanto designa «el modo específicamente humano de dar forma a las disposiciones y capacidades naturales del hombre»" ${ }^{240}$.

Es necesario enfatizar que, para Gadamer, ninguna transformación formativa individual se da adecuadamente sin el concurso del «otro». Bajo el influjo de Hegel, asevera que un individuo se educa junto a sus semejantes porque todos son seres estimulados a la conversación ${ }^{241}$ por estar constituidos por el lenguaje. A raíz de esto va a insistir en la importancia que tiene la capacidad de «escucha», esa disposición por comprender a los demás o tomar en cuenta sus horizontes, dentro de una dinámica dialógica de preguntas y respuestas. La escucha atenta es lo que posibilita el “entenderse unos con otros (Miteinander-sich Versteben)",242 y, como fruto de esto, la búsqueda de lo que tiene sentido y el logro de lo que es importante para el bien común. Es tal la relevancia de esta capacidad de apertura que Gadamer llega a decir que la hermenéutica "es la teoría de que hay que aprender a oír"243.

Como podemos apreciar, la formación, en la hermenéutica gadameriana, es éticamente demandante porque implica, además de lo que expusimos más arriba, vigilancia (Wachsamkeit) de la conciencia moral para "hallarse despierto en consonancia con la situación" ${ }^{244}$; uso de la racionalidad práctica (phronēsis) en cuanto orienta la voluntad y es la fuerza conformadora o reguladora "de la praxis

Conill, J., Ética hermenéutica. Crítica..., op. cit., p. 65.

Cf., Gadamer, H-G., La Educación es..., op. cit., p. 39.

Koselleck, R. y Gadamer, H-G., Historia y Hermenéutica..., op. cit., p. 119.

243 Gadamer, H-G., Acotaciones hermenéuticas, Trad. Ana Agud y Rafael de Agapito, Madrid, Editorial Trotta, 2002, p. 235.

244 Grondin, J., Introducción a Gadamer, Trad. Constantino Ruiz-Garrido, Barcelona, Editorial Herder, 2003, p. 169. 
humana y social" ${ }^{245}$; capacidad de discernimiento comprensivo (Synesis) como apreciación ética que se coloca "en la misma situación donde debe actuar el otro",246 $\mathrm{y}$, finalmente, constante disposición a ampliar el horizonte contextual y temporal para incorporar formas culturales disímiles de apreciar y de ver.

Todos estos aspectos caracterizadores esenciales de la Bildung nos llevan al sensus communis $^{247}$ o sentido común que es el otro concepto sin el cual es imposible tener una comprensión adecuada de cómo se configura un proceso formativo, tanto en el plano individual como el social, aparte de que nos coloca cercanos "a la tradición humanista e indagar qué se puede aprender de ella para la forma de conocimiento de las ciencias del espíritu"248.

El crítico R. Beiner señala que: "[t]anto Vico con su continuación de la tradición retórica del humanismo, cuanto Shaftesbury, con su influencia en la filosofía escocesa del "sentido común", ayudaron a renacer y mantener viva la antigua idea romana del Sensus Communis" ${ }^{249}$. Por su parte, Gadamer sostiene que el segundo autor tuvo una fuerte influencia en el siglo XVIII y entre sus aportes teóricos está el de situar "la apreciación del significado social de wit y humour bajo el título

245 Gadamer, H-G., Verdad y Método II..., op. cit., p. 245.

246 Gadamer, H-G., El problema de..., op. cit., p. 93.

247 Leandro Martín nos comenta que Gadamer, fiel a la tradición antigua, presenta al sensus communis como apropiado para encontrar rastros que podrían explicar la Bildung en nuestro tiempo. Igualmente, refiere el mencionado autor que el filósofo alemán toca dos puntos que son fundamentales: la "ampliación de la restringida concepción moderna de retórica, en tanto coacción, como [...] descubrir que la articulación lingüística de nuestra experiencia en el mundo no se limita sólo al discurso científico". (Martín, L., "El origen retórico del concepto de formación en la hermenéutica gadameriana, en Revista de Humanidades, Vol. 15-16, Santiago de Chile, Universidad Nacional Andrés Bello, Junio-diciembre 2007, pp. 51).

248 Cf. Gadamer, H-G., Verdad y Método I..., op. cit., p. 48.

249 Beiner, R., El juicio político..., op. cit., p. 50. 
de sensus communis" ${ }^{250}$. El humor y el ingenio son, para Shaftesbury, armas de la razón que, en tanto criterios de verdad, se oponen a todo tipo de dogmatismo (fundamentalmente el religioso). Por lo tanto, la jerarquía y la criticidad que ambos ostentan no tienen nada que ver con la imagen estereotipada que los considera frutos del cinismo o de una cultura dominada por hombres sin formación.

Tiene razón el filósofo británico al relacionarlos con el «sentido común» porque éste es una inclinación natural, sustanciada por la inmediatez que se caracteriza por ser un «bien compartido» que funciona como antídoto contra los conflictos y por permitir a los individuos utilizar su capacidad de juzgar las acciones en bellas o feas y a las obras de arte en buenas o malas. Tenemos, entonces, que Wit, humour y sensus communis son facultades que están encaminadas a formar el carácter (character) del ser humano dentro de una moral de los sentimientos emparejada con la estética. En este enfoque es clara la impronta que Shaftesbury recibe "de los clásicos romanos [a través] de sus intérpretes humanistas" ${ }^{, 251}$.

Aparte de referirse a este filósofo, Gadamer hace mención de otros autores ${ }^{252}$ y

Gadamer, H-G., Verdad y Método I..., op. cit., p. 54.

Ibídem.

252 Uno de esos casos es el prelado F.Ch. Oetinger, un teólogo que va en contra del concepto escolástico de Sensus Communis por considerar que es tomado, exclusivamente, en su veta racionalista. Igualmente, a partir de las Sagradas Escrituras, sostiene que no se pueden aplicar los métodos matemático y demostrativo al «sentido común» porque los intereses investigativos de estos campos se orientan en otra dirección y no aportan nada al respecto. Va a proponer, desde el concepto metafórico de «método generativo", que se considere "la Escritura al modo de una siembra, con el fin de que la justicia pueda ser implantada y crecer" [como una] ley universal [...] de la creación divina y por tanto del espíritu humano" (Ibíd., pp. 58-59). Para este prelado, el verdadero sensus communis expresa la vida (vita) frente a la violenta escisión de la naturaleza que producen los cálculos y los experimentos. 
corrientes $^{253}$ en torno al tema. Con todo, en este apartado nos interesa detenernos en Giambattista Vico porque es el que realmente tuvo una influencia decisiva en la hermenéutica gadameriana. Hablamos de un historiador italiano que es innovador, controversial; representa la refinada tradición humanista y forma parte del valioso bagaje teórico universal.

Es importante observar que Gadamer estudia el pensamiento viquiano, tomando como referencia la obra Characteristicks ${ }^{254}$. No lo hará como un historiador de las ideas, sino que se enfrentará al texto buscando aquellos aspectos teóricos que le sirvan para la sustentación de su traza sobre el sensus communis y, de esta forma, fertilizar a las Ciencias del espíritu. Este esfuerzo gadameriano hay que verlo tomando en cuenta que desde el siglo XVIII hasta el XX, los planteamientos de Vico no tuvieron, por prejuicios y otros factores, la resonancia que deberían tener en vista de la magnitud de sus aportes teóricos.

Para Vico existe un «bien común» con la denotación profunda de pertenencia a todos los hombres que conforman a la humanidad. Su rasgo manifiesto es una totalidad que se da en una pluralidad de expresiones histórico-culturales. No obstante, son las comunidades concretas la gran meta a la cual apunta la intención del filósofo para desarrollar el sensus communis o el ideal de la eloquentia de los humanistas. Hablar bien o con elocuencia, para Vico "ha sido siempre una fórmula de dos caras, y no meramente un ideal retórico. Significa también decir lo correcto, esto es, lo

${ }^{253}$ Gadamer reconoce que en la cultura alemana el sensus communis tiene una "resonancia estoicoiusnaturalista" (Ibíd., p. 54).

254 Se trata, realmente, de: Characteristicks of men, manner, opinions, time. En uno de sus ensayos se halla Sensus Communi, and Essay on the Freedom of Wit and Homour. 


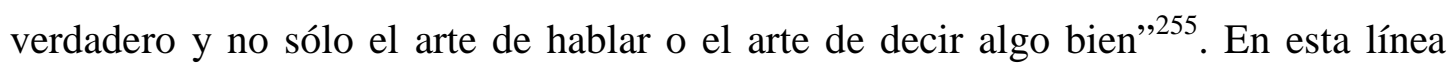
sintetiza una retórica-filosófica. Esto es bien importante, pues Vico nos avisa acerca de los límites que les toca a las ciencias naturales y resguarda la idea de cultivar la prudencia y la elocuencia en función de una formación del sentido común "que no es más que la "sabiduría de los antiguos" 256 junto con el de la educación.

Entonces lo fundamental aquí es que Vico acepta "lo verosímil, lo verdadero con el significado de un saber práctico (phrónesis), un saber distinto" 257 que no es abstracto. Se podría decir que el sensus communis se dirige fundamentalmente a ver lo qué es lo justo en relación con el bien común propio de todos los seres humanos que participan en él y que se adquiere en el devenir de la vida cotidiana ${ }^{258}$.

En su hermenéutica dialógica, Gadamer comparte este impulso viquiano. De hecho, afirma que el sentido común "no significa en este caso evidentemente sólo cierta capacidad general sita [asentada] en todos los hombres, sino al mismo tiempo el sentido que funda la comunidad"259. Esto implica una articulación práctica dentro de tradiciones concretas y significativas de un determinado grupo, porque es a partir de los valores y saberes forjados en común lo que darán las pautas ético-políticas adecuadas a la vida social.

Según Gadamer -evocando a Vico y Shaftesbury- el sensus communis "no es primariamente una aptitud sino que abarca siempre el conjunto de juicios y baremos

\footnotetext{
Gadamer, H-G., Verdad y método I..., op. cit., p. 49.

Ibíd., p. 50.

Ibíd., p. 51.

Cf., Ibíd., p. 52.

Ibid., p. 50.
} 
de juicios que lo determinan en cuanto a su contenido"260. La razón, según el pensador alemán, se fundamenta en la noción donde aparecen los juicios, “justo e injusto, correcto e incorrecto" ${ }^{261}$. Esto es bien importante, ya que nuestro autor considera que un sano juicio a diferencia de lo que piensa Baumgarten -lo individualsensible- no debe juzgarse desde lo particular según la visión que se tiene de lo general.

El sensus communis gadameriano, en consonancia con Vico, es un saber práctico que, aparte de estar en una constante confrontación con las pretensiones del espíritu científico ${ }^{262}$, apunta hacia el ideal de la eloquencia, es decir, ese conversar siempre ajustado a un buen diálogo, en el que se combina la excelencia retórica con la virtud ética. En su cultivo se recogen las convicciones esenciales compartidas en una generalidad concreta que orienta la voluntad de una comunidad, de un pueblo o de un grupo; los individuos se sienten identificados con ella. Se podría sintetizar diciendo que el sentido común es la expresión de lo verdadero y lo justo que "produce un ascenso a lo universal, pero no a la manera de las leyes científicas"263 sino apartándose del particularismo y abriendo horizontes que permitan la comprensión de la finitud humana.

\footnotetext{
Cf. Ibíd., p. 63.

Ibídem.
}

${ }^{262}$ La crítica apunta a R. Descartes y B. Spinoza por nombrar dos grandes pensadores que intentan dar una explicación científica y medir cuantitativamente mediante el método matemático los asuntos axiológicos. Sin embargo "el verdadero problema que plantean las ciencias del espíritu al pensamiento es que su esencia no queda correctamente aprehendida si se le mide según patrón del conocimiento progresivo de leyes" (Ibíd., p. 32). Gadamer hace referencia igualmente a Herman Helmholtz, un científico que intentó diferenciar las ciencias naturales y las del espíritu o la inducción lógica de lo "artístico-instintivo". A pesar de este gran esfuerzo cayó irremediablemente en un claro psicologismo porque la inducción sería para las ciencias del espíritu una "conclusión inconsciente" (Ibíd., p. 33).

263 Grondin, J., ¿Qué es la..., op. cit., pp. 72-73. 
La importancia que tiene el sentido común como pilar social cardinal es que expresa la verdad y la justicia enraizadas contextualmente pero con impulso universal. No es un saber que se regodea en sí mismo, sino un saber práctico que permita hallar lo que es innegablemente necesario, dentro de lo que cabe considerar por plausible y correcto. Esta referencia a una praxis que se nutre de criterios tejidos en común es dable en cuanto supone una phronēsis: "un conocimiento que no es técnico y que se expresa como saber social en el trato con nuestros semejantes"264.

Un saber técnico se sustenta en principios que son objetivos, medibles o cuantificables y el saber práctico, en cambio, se orienta hacía principios más generales e implica una realidad sumida en un determinado contexto histórico y basada en un carácter axiológico-experiencial. Por tanto, los principios generales que se orientan hacía el saber práctico facilitan la producción de lo esperado, en el sentido de lo verdadero y lo justo, es decir, se abocan a amparar y someter éticamente una determinada situación. Este es el significado de la prudencia en Aristóteles que, en este caso, estaría contemplada como una virtud intelectual ${ }^{265}$. Según la profesora Nowys Navas, Gadamer "se detiene a considerar «la actualidad hermenéutica de Aristóteles» centrando su atención en el libro VI de la Ética a

264 Lulo, J., "La vía hermenéutica: Las ciencias sociales entre la epistemología y la ontología", en Schuster, F. (Comp.). Filosofía y métodos de las Ciencias Sociales, Buenos Aires, Editorial Manantial, 2011, pp. 195-196.

265 De acuerdo con Aristóteles, el hombre necesita para actuar tanto de las virtudes éticas o del carácter como de las intelectuales, dianoéticas o de la razón. Éstas últimas son: la ciencia, el arte, la sabiduría práctica, la razón intuitiva y la sabiduría teórica. La tercera, es la que toma Gadamer de la ética aristotélica porque se orienta a "determinar la justa medida en qué debe observarse la conducta" (Moreau, J., Aristóteles y su escuela, Buenos Aires, Editorial Universitaria de Buenos Aires, 1972, p. 204). 
Nicómaco y, más específicamente, atendiendo a la phronēsis, virtud dianoética central en la «filosofía práctica» del estagirita»266.

La virtud dianoética, en su dimensión intelectual de prudencia, consiste en deliberar racionalmente antes de llevar a cabo cualquier acción. Se trata de un conocimiento práctico que se logra en el ejercicio diario mediante la reflexión y la experiencia. Cuando el hombre es prudente razona qué debe hacer y elige las distintas posibilidades que se le presentan en cada momento de su vida, es como apunta Giovanni Reale "[1]os verdaderos fines y el verdadero objetivo son aprehendidos por la virtud que dirige correctamente los actos de la voluntad" 267 . Como podemos apreciar, creemos que este análisis sobre la phronēsis es decisivo para la convivencia de las ciencias del espíritu porque, tratándose de un sentido común de lo verdadero y lo justo, permite la formación beneficiosa y conveniente tanto para el desarrollo del individuo como de la comunidad y, sobre todo, no puede ser sustituido ni monopolizado por el pensamiento científico.

El sensus communis, para Gadamer, es la fuente de la tradición humanística que le permite al individuo desarrollar una «capacidad de juicio» a tono con la moral y la función cognoscitiva. El análisis de dicha capacidad le permitió al autor retomar los conceptos básicos del humanismo frente al dominio de la concepción metodológica y el arrollador vigor estético, fundamentalmente, kantiano.

\footnotetext{
266 Navas, N., "Phrónesis y Hermenéutica", en Apuntes Filosóficos UCV, Vol. 21, № 40, Caracas, 2012, p. 68.

267 Reale, G, Introducción a Aristóteles, Trad. Víctor Bazterrica, Barcelona, Editorial Herder, 1992, p. 106.
} 
El primer trance de quiebre, según Gadamer, donde la tradición humanista quedó fuera de 'circulación’ o no se le reconoció en su “pretensión específica de verdad"268 y conocimiento, fue cuando se impuso el criterio metodológico como la única vía para la conquista de lo que es verdadero, seguro y exitoso. Esto trajo como consecuencia que las ciencias del espíritu perdieran legitimidad cognoscitiva y capacidad de influir significativamente en el fluir histórico.

La segunda encrucijada por donde pasó el humanismo y que Gadamer lamenta es la "fatalidad de la estetización"269 de la facultad de juicio. Este fenómeno se produce, en un primer momento, de la mano de la filosofía moralista inglesa (escocesa), en sus representantes más destacados: D. Hume, A. Smith, F. Hutcheson y Shaftesbury. De acuerdo con esta tradición ${ }^{270}$ del siglo XVIII, ni los juicios morales ni estéticos obedecen a la razón, sino al sentimiento (sentiment-taste). Esto significa que no es imprescindible guiarse por el raciocinio ${ }^{271}$ para actuar moralmente y decidir entre el bien o el mal o valorar estéticamente lo bello o lo feo. No existe ningún principio de la naturaleza humana que afirme que la razón precede a estas prácticas.

268 Gadamer, H-G., Verdad y Método I..., op. cit., p. 73.

269 Grondin, J., Introducción a la hermenéutica filosófica, Trad. Ángela Ackermann Pilári, Barcelona, Editorial Herder, 2002, p. 160.

270 Un representante de esta tradición es Adam Smith, un filósofo escocés que publicó una obra titulada Teoría de los sentimientos morales. Según este autor, los sentimientos que se experimentan cuando se aprueba a una persona o un acto provienen de cuatro fuentes. "Primero, simpatizamos con los motivos del agente; segundo, asumimos la gratitud de quienes han cosechado el beneficio de sus acciones; tercero, observamos que su conducta ha sido compatible con las reglas generales por las que suelen operar esas dos simpatías; y, finalmente, cuando consideramos tales acciones como parte de un sistema de conducta que tiende a promover la felicidad del individuo o la sociedad, parecen derivar de esta utilidad una belleza no distinta de la que adscribimos a una máquina bien planeada" (Smith, A., Ensayos filosóficos, Trad. Carlos Rodríguez Braun, Madrid, Ediciones Pirámide, 1998, pp. 247-248). Como se puede apreciar, Smith apela a argumentos sentimentales.

271 Cf., Gadamer, H-G., Verdad y Método I..., op. cit., pp. 61-62. 
El segundo momento del viraje hacia la estetización del juicio se origina, según Gadamer, en Kant y con mayor repercusión filosófica. De hecho, podemos apreciar que este filósofo, en su Crítica de la facultad de juzgar, nos dice lo siguiente: "la facultad de juzgar estética puede, antes que la intelectual, llevar el nombre de un sentido a todos común" 272 . Se trata de una facultad "que en su reflexión tiene en cuenta, en pensamiento (a priori), el modo representacional de cada uno de los demás",273.

Observamos que esta forma de pensar de Kant sobre el sensus communis se aparta del caracterizado por la tradición romana, la humanística y actualizada por Vico. La noción queda fuera de la filosofía moral porque la idea kantiana de un «a priori» o de un imperativo al no tener una base en los sentimientos excluye de ésta la «reflexión comparativa». Así, lo formal hace una 'limpieza' del concepto ético de los momentos estéticos. Gadamer sintetizará este viraje estético kantiano diciendo que "la incondicionalidad de un mandamiento moral no puede fundarse en un sentimiento, ni siquiera aunque uno no se refiera con ello a la individualidad del sentimiento sino al carácter común de la sensibilidad ética" ${ }^{\text {274 }}$. Además, en la visión kantiana se "restringe el concepto de gusto al ámbito en el que puede afirmar una validez autónoma en calidad de principio propio de capacidad de juicio" ${ }^{275}$, haciendo que este juicio no tenga un carácter lógico sino estético: que no se convierta en un

272 Kant, I., Critica de la facultad de juzgar, Trad. Pablo Oyarzún, Caracas, Monte Ávila Editores, 2006, p. 236.

273 Ibíd., p. 234.

274 Gadamer, H-G., Verdad y Método I..., op. cit., p. 64.

275 Ibíd., p. 73. 
referencial de conocimiento. En definitiva, el sentido común como base de los juicios humanos no desempeña en Kant un papel preponderante.

Sin duda alguna, Kant ha hecho un esfuerzo denodado por resaltar la capacidad de juzgar por la vía de la distinción entre los juicios reflexionantes y los determinantes, es decir entre aquellos que permiten "que la imaginación cree sus propias ideas para organizar la experiencia en un contexto interpretativo más amplio"276 y los "que están controlados por los conceptos puros del entendimiento"277 o entre los que van de lo universal a lo particular y los que hacen el trayecto inverso. Empero, según Gadamer, Kant se ocupa "ciertamente de una oscura distinción de la capacidad de juicio que llamamos sentimiento",278 y que de alguna manera no deja que el juzgar funcione según conceptos. En fin, lleva al «giro estético del concepto de juicio»"${ }^{279}$.

Frente a la 'embestida' estética Gadamer retoma, como dijimos al principio, la tradición humanista. En ésta, la capacidad de juicio (Urteilskraft) ha mantenido históricamente una estrecha y dinámica correspondencia con el sensus communis. Lo especifica de esta forma: “«el sano sentido común», llamado también «entendimiento común» (gemeine Verstand), se caracteriza de hecho de una manera decisiva por la capacidad de juzgar” 280 , esto es, que lo individual se subsume bajo lo general.

Conill, J., Ética hermenéutica. Crítica..., op. cit., p. 21.

Ibídem.

Gadamer, H-G., Verdad y Método I..., op. cit., p. 65.

Conill, J., Ética hermenéutica. Crítica..., op. cit., p. 73.

Kant, I., Crítica de la..., op. cit., p. 61. 
Con esta idea como telón de fondo, el filósofo se empeñó, en su hermenéutica filosófica, en mostrar que la «capacidad de juzgar» no se reduce al gusto como planteaba Kant; que tampoco es un valor inferior del espíritu humano y una magnitud despreciable de conocimiento. El juzgar es una dimensión humana dinámica que se engendra en una perpetua situación de perplejidad $^{281}$ debido a que carece de un criterio definitivo que pueda aplicarse infaliblemente en las diferentes circunstancias. No puede enseñarse sino que se perfecciona a través de un arduo adiestramiento por lo que se asemeja a la experiencia que no se aprende con principios y cánones fijos o impuestos sino que consiste ejercitarse, vivirse con audacia y en algunos casos con mucho sufrimiento.

Después de un arduo proceso de sedimentación, muchos juicios se convierten en pautas no infalibles pero sí válidas de orientación y evaluación a las que pueden apelar seres humanos que viven en épocas y en circunstancias diversas. Nutrirse de este magma de saber práctico y de experiencias es esencial porque, plantea Gadamer, un hombre que posea un «sano juicio» no está simplemente "capacitado para juzgar lo particular según puntos de vistas generales, sino que sabe también qué es lo que realmente importa, esto es, enfoca las cosas desde los puntos de vistas correctos, justos y sanos"282. En estos aspectos se asemeja al «gusto» que es el último de los conceptos básicos del humanismo que estudia y actualiza Gadamer.

El tema sobre el gusto también es abordado por Gadamer tomando en consideración a Kant. Este pensador, debido al cometido o al efecto de su Crítica de

281 Cf. Gadamer, H-G., Verdad y Método I..., op. cit., p. 62.
282 Ibíd., p. 63. 
la facultad de juzgar, "subjetivó y estetizó el gusto y, por lo mismo, le negó su valor cognoscitivo" ${ }^{\text {283 }}$. Planteó una distinción entre la belleza libre y la adherente. La primera se refiere a la belleza de la naturaleza: contemplar una flor, un paisaje natural o un río. En este tipo de belleza libre no interviene ningún concepto que establezca lo que deba ser la flor o su utilidad; no hay ninguna perfección objetiva añadida por lo que el juicio es totalmente puro. En cambio, la adherente posee una determinada estructura como en los casos de una catedral, un hombre y un gato. Aquí estos conceptos están mezclados con fines determinados o deben cumplir funciones específicas tal como aparecen en el mundo sujetos a los fines humanos y, por tanto, dejan de ser una belleza pura. Una catedral es bella pero a su vez cumple una función, una utilidad; está mediada y penetrada por el pensar humano.

Aun con esta distinción, lo que hace Kant, en opinión de Gadamer, es reforzar el carácter subjetivo y estético del «gusto» aun cuando la "larga historia de este concepto que precede a su utilización por Kant como fundamento de su crítica de la capacidad de juicio permite reconocer que originalmente el concepto del gusto es más moral que estético"284. Esta restricción kantiana como otras de igual calado ha llevado a Gadamer a retomar el significado o la utilización de la noción de gusto dentro del espíritu humanista clásico y moderno. Así, por ejemplo, nos habla de Baltasar Gracián quien considera que el gusto tiene como punto de partida lo sensorial.

283 Grondin, J., Introducción a la..., op. cit., p. 160.

284 Gadamer, H-G., Verdad y Método I..., op. cit., p. 66. Las cursivas son de Gadamer. 
Lo primero que nos dice este teólogo jesuita, según Gadamer, es que "el más animal e interior de nuestros sentidos, contiene sin embargo ya el germen de la distinción que se realiza en el enjuiciamiento espiritual de las cosas" ${ }^{285}$. Esta idea es de una importancia capital por cuanto recoge una tendencia, en el pensamiento occidental, de perfilar lo que se entiende por gusto o preferencia en su relación con la moral, la libertad y lo social, tanto en el ámbito individual como el colectivo. Además, de sus posibles proyecciones teóricas han salido unas pautas concatenadas que fueron cobrando vigencia progresivamente a tal punto que Gadamer, en una época determinada, se valió de ellas para la construcción de su texto fundamental: Verdad y método.

En el comienzo de esas pautas tenemos, la "espiritualización de la animalidad" ${ }^{286}$. El hombre ya no responde automáticamente a sus impresiones externas (o internas) como lo haría un animal frente a las 'cosas' porque "visto un león, están vistos todos, y vista una oveja, todas; pero visto un hombre, no está visto sino uno [que] tiene su gusto y su gesto" 287 . Un gusto (sensorial) que le permite elegir desde el juicio y mantenerse a distancia de los objetos que le afectan en la vida ${ }^{288}$. Por eso, Gracián piensa que este jalón «natural-espiritual» proyecta al hombre hacia una formación (Bildung) que "no sólo debe al ingenio (Geist) sino también al gusto (Geschmack) $^{, 289}$.

Ibíd., p. 67.

Conill, J., Ética hermenéutica. Crítica..., op. cit., p. 74.

Gracián, B., El criticón, Tom. I, Madrid, Editorial Espasa-Calpe, 1971, p. 170.

Cf., Gadamer, H-G., Verdad y Método I..., op. cit., p. 67.

Ibídem. 
Lo que Gracián propone es que el hombre haga uso pleno de su capacidad de la razón para saber diferenciar y elegir con tino y «dar en el hito» o en la dificultad, pues es así como llega a ser un hombre discreto porque está en su punto ${ }^{290}$ y ejerce su justa libertad que no es más que salir de su inmediatez. Lo que está considerando este teólogo aquí es que la formación a través del ingenio y el gusto es lo más apropiado para a una buena sociedad. Una que "ya no se reconoce ni legítima por nacimiento y rango, sino fundamentalmente sólo por la comunidad de sus juicios" ${ }^{\text {291 }}$ en la que se deja atrás la cerrada concepción estamental.

Bajo la impronta de Gracián y de otros pensadores, Gadamer aborda el gusto como un tipo de conocimiento que pertenece a la capacidad de dar juicios o juzgar292. Aunque presume de validez, ésta no se basa en argumentos sino en un «sentido» que se percibe esencial para la orientación de la vida. Pero queda por dilucidar lo siguiente: si el gusto está sujeto a un sentido del que no se posee un conocimiento previo o a priori ¿cómo se debe encarar esta cuestión con el objetivo darle relevancia ética? Gadamer, ante esta situación, prefiere primero advertirnos que es "muy significativo comprobar hasta qué punto solemos ser sensibles a este fenómeno negativo en las elecciones y discernimientos del gusto"293. Luego nos aclara que "la capacidad de juicio son maneras de juzgar lo individual por referencia a un todo, de examinar si concuerda con todo lo demás, esto es, si son «adecuados»" ${ }^{294}$. Una ética

\footnotetext{
Ibídem.

Ibídem.

Cf. Ibid., p. 68.

Ibídem.

Ibíd., p. 70.
} 
del buen gusto concierne a una búsqueda de sentido que supone cierta incertidumbre y una capacidad de adaptación de los saberes tradicionales para darle valor-fuerza una vez que se ha elegido y discernido lo que conviene o no. Lo que caracteriza a este tipo de ética es el ejercicio y la atención permanentes.

El gusto, desde esta perspectiva, es una dimensión ético-epistemológica que Gadamer lo llama "modo de conocer" capacidad de crear cierta distancia subjetiva de aquellas inclinaciones personales que buscan abrirse camino más allá de la conciencia o de los principios orientadores. Esto es pertinente si observamos que es "muy posible que alguien tenga preferencia por algo que sin embargo su propio gusto rechaza. En esto las sentencias del gusto poseen un carácter peculiar" ${ }^{296}$ de experiencia. La clave, entonces, consiste en lograr juicios preferenciales válidos en cuanto responden a exigencias éticas de humanidad y de universalidad.

Lo más importante para Gadamer es que el gusto es un fenómeno que trasciende lo individual para configurarse como un fenómeno social (sensus communis). Claro está que el autor no da cuenta de una preferencia individual, una moda pasajera o una generalización social impuesta. La moda es fenómeno de preferencia social masiva que no hay que confundir con el gusto, aunque de alguna manera estén relacionados en su pretensión de universalidad. En el gusto la "norma no está impuesta por el hacer de todo el mundo, no se reduce a una mera dependencia social, sino [que] debe determinarse como una capacidad de discernimiento espiritual,

295 Ibíd., p. 68. Las cursivas son del autor.

296 Ibídem. 
para adaptar incluso la moda del gusto" ${ }^{297}$. Con todo, Gadamer es consciente de que el estilo de vida actual esté totalmente ligado al gusto pero orientado obsesivamente al «consumo» lo que hace que los individuos estén aguijoneados, por todos los medios, a confundir éste con aquél ${ }^{298}$.

A través del gusto, Gadamer está apostando a esos "elementos estables e inmutables de [la] convivencia social, así también [al] despertar de una conciencia de solidaridad"299. Piensa que con estos ideales posibles podría surgir un tipo de humanidad que "lentamente comenzara a entenderse como humanidad, es decir, a entender, que está recíprocamente vinculada tanto en lo que respecta a su florecimiento como a su decadencia y que tiene que solucionar el problema de su vida sobre este planeta" ${ }^{, 300}$.

Todo lo que hemos expuesto hasta aquí nos permite ampliar aún más el horizonte de la formación (Bildung) gadameriana a través de la siguiente pregunta: ¿cuáles son las consecuencias, implicaciones y alcance político que tiene dicho concepto en el mundo actual?

\subsection{Alcance político de la Bildung en el complejo mundo actual}

Los conceptos básicos de la tradición humanística sintetizan la lozanía y el carácter «político» de la Bildung, trazas-clave que nos permitirán abordar tres problemas que preocuparon intensamente a Gadamer y que siguen angustiando al

Conill, J., Ética hermenéutica. Crítica..., op. cit., p. 75.

Cf. Gadamer, H-G., Verdad y Método I..., op. cit., p. 69.

Gadamer, H-G., La razón en ..., op. cit., p. 56.

Ibídem. 
hombre contemporáneo: el poder de manipulación de las ciencias a través de la fabricación (herstellen), el deterioro de la razón social por la proliferación de expertos y funcionarios y la "diversidad de las lenguas y la comprensión del mundo" ${ }^{\text {"301 }}$. Nos proponemos exponer las potencialidades y puntos novedosos de la hermenéutica gadameriana con la finalidad de mostrar que su teoría de la formación humana es pertinente, factible y necesaria en los tiempos difíciles o convulsionados que corren.

Quisiéramos iniciar el análisis de los tres problemas haciendo un inciso importante sobre lo que Gadamer entiende por «lo político» para conjurar, de esta manera, la imagen distorsionada que se tiene sobre este original pensador en cuanto a su supuesto 'desinterés' por las cuestiones de índole política y su 'fijeza' en la ética. De hecho, se piensa que el filósofo no presenta, en sus obras, soluciones políticas contundentes o viables sino que más bien revela salidas éticas o idealistas o para utilizar el vocabulario de Maquiavelo ${ }^{302}$, en vez de atenerse a lo que es la 'realidad' apela a lo que debería ser.

Es indudable que la preocupación filosófica más importante que recorre las obras de este pensador alemán es la Ethik a la luz de Platón, Aristóteles, Vico, Hegel y otros connotados e influyentes pensadores. Su eje central es una ontología del lenguaje que envuelve una visión optimista del hombre. Se podría afirmar que el carácter formativo-ético gadameriano es una apuesta por el diálogo, la tolerancia, la búsqueda del bien común que se plasma en un ser humano responsable, prudente y

$301 C f$., Gadamer, H-G., Arte y verdad de la palabra, Trad. José Francisco Zuñiga y Faustino Oncina, Barcelona, Ediciones Paidós Ibérica, 2009, pp. 111-130.

302 Cf., Maquiavelo, N., El príncipe, Trad. Helena Puigdomenech, Madrid, Editorial Tecnos, 1987, p. 61. 
abierto a las diferencias porque sabe escuchar ${ }^{303}$. Grandes ideales que funcionan como acicates para hacer frente a los desmanes de toda índole azotan la realidad social; son capacidades imprescindibles en los tiempos que corren signados por el escepticismo, la apatía, la exclusión y el abuso del poder. Tenemos, entonces, que la ética lleva en su seno siempre la negación a todo tipo de vejamen de la condición humana pero, a la vez, la afirmación en las posibilidades infinitas de construcción de sociedades más libres y justas dentro una labor común de convivencia que trasciende la agresividad y la competitividad.

Sin embargo, la dimensión política también está presente en todos los textos de Gadamer. Su expresión es menos visible, más limitada y, en muchos fragmentos o párrafos, difícil de detectar o comprender. En todo caso, lo que sí es seguro es que el autor estaba en sintonía permanente con el mundo que le tocó vivir. Su concepción política sintetiza, de forma dialéctica, teoría-práctica y crítica-propuesta. Nos da las siguientes pautas para que entendamos su línea de investigación: "la política se basa en que nadie vive según su conciencia en aislado y sólo para sí, de manera que nadie puede crear por sí solo sus propias condiciones para una actuación responsable"304. En otros términos, para Gadamer la primera responsabilidad es la que tiene el individuo consigo mismo pero para lograr que esta condición se realice con conciencia, sentido y prudencia es imprescindible que su proceso de formativo

\footnotetext{
303 Sólo cuando un individuo escucha a su semejante se abre el verdadero camino para vivir solidariamente. Gadamer, en todos sus escritos, buscó denodadamente defender al «otro» en sus derechos y formas de vida. Esto explica porque nos invita constantemente a escuchar con detenimiento, a superar el individualismo exacerbado y el afán de imponer las ideas a cualquier precio.

304 Gadamer, H-G., Acotaciones hermenéuticas..., op. cit., p. 140.
} 
(Bildung) se dé dentro un contexto de entendimiento, educación y con un ordenamiento social compartido. El propio autor nos dirá que ningún individuo "se construye su propia vida siguiendo un plan libremente elegido"305 sino que éste forma parte de una tradición de la que el individuo puede extraer fuerza y orientación.

La clave de la política, en Gadamer, es perfilar un entramado de acciones conjuntas, nunca definitivo o cerrado, en donde lo individual y lo social se movilicen desde la libertad y la creación. La praxis ${ }^{306}$ del individuo es su comportamiento consciente y despierto que "conlleva autocontrol, autocrítica y ejemplaridad" $" 307$. Es un trabajo que supone tesón, entereza y aprender de los propios errores ${ }^{308}$, por lo que no cabe el aplazamiento o la pasividad. En cambio, la praxis social consiste en determinar "fines comunes mediante una elección sensata hecha en común, y en acomodarlos por medio de una reflexión práctica a lo que hay que hacer en [una] situación concreta"309. Es un interminable paso de lo universal a lo particular mediante los provisionales ajustes reflexivos y decisivos.

Ambas praxis, que se influyen mutuamente, tienen como formas de forcejear con la realidad la crítica y la búsqueda de salidas institucionales frente a las crisis. Parten de los principios de que no todo debe ser tolerado y de que no todo es

\section{Ibídem.}

306 Para Gadamer, la praxis es "la totalidad de [los] asuntos prácticos, toda la actuación y el comportamiento humanos, la autoinstalación en su totalidad del hombre en este mundo; por tanto, también su política, la legislación y el asesoramiento políticos" (Dutt, C. (edit.), En conversación con Hans-Georg Gadamer. Hermenéutica, estética, filosofía práctica, Trad. Teresa Rocha Barco, Madrid, Editorial Tecnos, 1998, p. 95). En este punto el filósofo alemán es fiel al pensamiento aristotélico.

307 Ibídem.

308 Gadamer, H-G., La educación es..., op. cit., p. 48.

309 Dutt, C., En conversación con..., op. cit., p. 104. 
expresión de libertad, como insistentemente se argumenta de forma interesada. Se empeñan, cada uno desde su espacio específico, en ser una voz fuerte que logre influir en la dirección y práctica de la política social.

Aclarados los puntos sobre el fondo ético-político de la Bildung, sí podremos introducirnos ahora a la primera problemática que abordó Gadamer en su construcción intelectual: la manipulación de la ciencia a través de la fabricación y la racionalidad instrumental y sus consecuencias en todos los tópicos del «mundo de la vida».

La sociedad de hoy se encuentra sumergida en una realidad eufórica técnicocientífica sin precedentes en la historia de la humanidad. Se halla determinada por la ciencia en la medida en que ésta no sólo intenta someter las fuerzas de la naturaleza sino que al mismo tiempo intenta influir en todos los ámbitos de la vida del hombre. Lo hace mediante la manipulación de las tecnologías o de una fabricación abrumadora de artefactos especializados y, sobre todo, de consumo masivo.

A partir de la Revolución Industrial, la productividad fruto de la capacidad inventiva ha sido, de alguna manera, para la humanidad un alivio a sus penurias o enfermedades y una opción válida a sus requerimientos vitales más urgentes (trabajo, vivienda, alimentación). Sin embargo, al mismo tiempo el ser humano corrió el peligro de inmolarse por su propia invención. Sumido, aceleradamente, en una racionalidad instrumental empezó manipular genéticamente (eugenesia) y a fabricar armas de destrucción masiva bajo los intereses de las grandes corporaciones militares. La industria farmacéutica con sus equipos especialistas no ven como finalidad la 
salud integral del hombre sino, más bien, producir para sus propios intereses crematísticos, apartándose así de la idea de que el ser humano es un fin en sí mismo, como planteaba Kant.

Tanto el panorama actual como el del futuro humano no se presentan nada halagadores, sino todo lo contrario, se encuentra en una situación que podría desembocar en la posibilidad de extinción de la humanidad y sus avances culturales, tal como los conocemos. A Gadamer le preocupa esta situación sobremanera y ve como una obligación del ser humano atender esta problemática. Piensa que la racionalidad dialógica debe jugar un papel fundamental para establecer los fines que estén acordes con el ethos humano. La industrialización creciente no debería chocar con el ideal de una filosofía práctica en sus valores humanísticos. Al respecto, Gadamer nos dice que "la hermenéutica [debe reinar] en la dimensión global de la convicción humana, y no solo en la ciencia” ${ }^{\circledR 310}$. Esto es de una significación decisiva ya que de no tomarse las previsiones correspondientes en torno a las consecuencias de los avances científicos se podría dar a un colapso social de grandes proporciones.

La propuesta gadameriana al respecto es, que desde la Bildung se puede comprender y al mismo tiempo canalizar el asunto polémico de la manipulación de la ciencia como de la fabricación. No desde una visión respecto a lo que se enseña en las universidades y ámbitos académicos sino en un sentido «orgánico». Así como se desarrollan el saber y la práctica de las ciencias también debe ampliarse la capacidad humana implícita para enfrentar sus retos. Esto es posible porque, para Gadamer en el

310 Gadamer, H-G., Elogio de la teoría, Trad. Luis Martínez, Barcelona, Editorial RBA Libros, S.A., 2013, p. 82. 
ser humano se da "una evolución, [...] a una figura que constituye lo que algo es",311 en toda la amplitud de sus posibilidades. Siendo esto así, la misión de la ciencia es preservar su "función integradora en los humaniora" para las generaciones futuras, en una política preventiva al estilo de las instituciones de la bioética o de las leyes que han creado para la protección del medio ambiente. Además, la cientificidad no se pierde o disminuye en nada si ésta se entronca en sus límites. La invitación que hace Gadamer, es que se evoque la racionalidad humana y que la ciencia esté al servicio de la vida del hombre, esto se logra si se tiene una formación que esté fundamentada en el ethos humano.

Pasamos al otro tema controversial que Gadamer abordó minuciosamente: la influencia de los expertos (expertus) en todas las esferas del quehacer humano. Cabe preguntarse: ¿por qué hay que estudiar este fenómeno? El propio filósofo se lo planteó en el siguiente tono: "hemos de preguntarnos si las razones que han conducido a la categoría de «los expertos» son de una legitimidad tan inequívoca que pueden ser aprobadas" ${ }^{„ 312}$. Dependiendo de la respuesta que se dé al respecto se asumirán diferentes pautas ético-políticas.

El experto es fruto de los signos de los tiempos. Bajo el dominio tecnológico sustituyó al antiguo operario. En una era de alta tecnología y de realidades complejas se hace imprescindible un tipo de persona que tenga la preparación necesaria para que pueda orientar adecuadamente y con una gran pericia. En muchas ocasiones presta

311 Gadamer, H-G., La herencia de Europa, Trad. Pilar Giralt Gorina, Barcelona, Ediciones Península, 1990, p. 98.

312 Ibíd., p. 129. 
inestimables servicios a la humanidad y en los casos de soluciones muy técnicas su presencia no puede ser sustituida por la doxa. Por todos estos aspectos, Gadamer nos indicará que el experto es hijo de la ilustración y que, por lo tanto, se encuentra a caballo entre la ciencia, en la que debe ser competente, y una práctica político-social contextual.

El problema con el experto es que, en palabras de Gadamer "pone de manifiesto que no es una instancia superior para decisiones últimas"313 o para las resoluciones fundamentales. Cuando en el ámbito social, un problema significativo se pone, exclusivamente, en manos de un experto se niega la posibilidad del diálogo necesario y pertinente que tiene que ver con los asuntos públicos o políticos. No se producen los acuerdos que supone el concurso de muchas personas con diferentes criterios y escala de valores. Muchas veces, la rigurosidad técnica no le permite al versado ('observador imparcial') abordar situaciones complejas si éstas se salen de su campo de conocimiento instrumental y, sobre todo, cuando concierne a la toma de decisiones con consecuencias trascendentales en el terreno ético o político que afectarían a muchísimas personas inocentes o vulnerables. El experto siempre tendrá la oportunidad de encontrar una 'excusa adecuada' en caso de que sus pronósticos no sean acertados.

En el plano individual, el endosar las decisiones a un experto podría traer como consecuencia la pérdida de la autonomía y, por tanto, la capacidad de decidir por cuenta propia. En otras palabras, se minaría la libertad de asumir plenamente las

313 Gadamer, H-G., Arte y verdad..., op. cit., p. 127. 
dificultades que se presentan. Gadamer es categórico al afirmar que debemos reconocer "nuestros propios límites y sepamos que todas las decisiones que tomamos como seres humanos debemos asumirlas y no endosarlas a ningún experto ${ }^{\text {314 }}$. En fin, si se dependiera continuamente de esta figura hegemónica, la vida se haría insípida por cuanto se anula todo sentido de riesgo, de aventura y de incertidumbre. La osadía quedaría en manos de unos pocos 'privilegiados' y la pasividad y el miedo se convertirían en un terreno fértil para la manipulación y el control de las conciencias.

Otra cuestión muy diferente, según Gadamer, es 'acudir' al (a lo) que tiene autoridad (Autorität) ${ }^{315}$. Representa, en el orden descriptivo, una posición opuesta con respecto al de experto puesto que en "la convivencia de los seres humanos existe siempre la autoridad y la subordinación, es decir, el poder"316. Su presencia no es esporádica y restringida a casos particulares porque el mismo proceso de coexistencia la produce y sedimenta en diversas esferas del actuar humano.

El sentido de autoridad es complicado y una de sus vertientes es la tradition $^{317}$ que ha sido desacreditada (sin éxito) por el pensar de la ilustración (Aufklärung), a

314 Ibíd., p. 144.

315 El término de autoridad en una de sus acepciones se relaciona con «prejuicio» (Vorurteil). A este concepto le han dado una fuerte carga negativa con la que se expresan posiciones a priori, irracionales y parciales basadas en la arbitrariedad. Más recientemente, se le ha dado el significado de juicio que no refleja verdad sino un ánimo de causar daño a lo juzgado. En cambio, Gadamer sostiene que los prejuicios pueden ser legitimados en el acto de la comprensión por formar parte de la tradición o ser contenidos de ella: "no significa pues en modo alguno juicio falso, sino que está en su concepto el que pueda ser valorado positivamente o negativamente" (Gadamer, H-G., Verdad y Método I..., op. cit., p. 337). Los prejuicios, en fin, encarnan las precomprensiones de la que los seres humanos se valen para orientar sus experiencias dentro de su mundo.

316 Gadamer, H-G., Arte y verdad..., op. cit., p. 133.

317 En el pensamiento filosófico gadameriano, la tradición no está cargada de connotaciones negativas. No representa una fatalidad ni está en conflicto con el uso de la racionalidad, como sostiene el pensamiento ilustrado y tampoco implica un conservadurismo paralizante. La tradición es un elemento básico para configurar un nuevo modo de comprensión, es una fuente para el 
través del falso dilema abstracto (razón-tradición). A pesar de esta y otras dificultades que acompañan al espíritu de Autorität lo más importante, según Gadamer, es resaltar el hecho de que ésta "no se otorga sino que se adquiere, y tiene que ser adquirida si se quiere apelar a ella",318. No se reconoce en una determinada persona o en alguna institución porque se decline al uso de la razón sino precisamente es por el uso de esa razón que se mantiene el respeto. Su aceptación "no tiene nada que ver con obediencia sino con conocimiento" ${ }^{, 319}$.

Tampoco la fuerza y la arbitrariedad se hallan dentro de las características de la autoridad. A lo que incita, desde su evidencia intrínseca, es al uso de una racionalidad dentro del ámbito de lo moral y lo político con la finalidad de encontrar aquellos medios adecuados que, surgidos de un compartir reflexivo, lleven a una comunidad a determinados fines orientados todos a fortalecer la solidaridad que, como diría Gadamer, "es la condición decisiva y la base de toda razón social”320.

Ahora nos queda por ver el último punto problemático en su relación con la incidencia política de la Bildung en la sociedad actual: la idea de la «diversidad de las lenguas y la comprensión del mundo». En opinión de Gadamer "se trata de un problema político por excelencia por el que deberemos responder ante la historia de la

ejercicio de la libertad y una vía expedita para adquirir alentadoras experiencias significativas. En este sentido, Gadamer no se cansó de insistir en que había que "familiarizarse con el papel que desempeña la tradición en el interior del comportamiento histórico, y de preguntarse por su productividad hermenéutica" (Gadamer, H-G., El problema de la conciencia ..., op. cit., p. 80).

318 Gadamer, H-G., Verdad y Método I..., op. cit., p. 347.

319 Ibídem. La cursiva es de Gadamer.

320 Gadamer, H-G., La razón en la época de la ciencia, Trad. Ernesto Garzón Valdés, Barcelona, Editorial Alfa, 1981, p. 57. 
humanidad" ${ }^{321}$. Con esta premisa como una espada de Damocles, el autor nos exhorta a discutir y actuar con premura, resolución y conciencia sobre la necesidad de una Koiné o de una convivencia común entre seres humanos de distintas culturas o criterios valorativos en la que prevalezca la vida y no la muerte, aunque a todos nos acompañe en trayecto empinado el dilema incertidumbre-esperanza por tratarse de una cuestión compleja que requiere mucho análisis, paciencia y comprensión.

La sociedad de la muerte denunciada por Gadamer que aun sigue presente se caracteriza por dos grandes tragedias: una es que nunca "antes la humanidad se había encontrado en posesión de medios a través de los cuales puede imposibilitar su propia existencia sobre este planeta" ${ }^{\text {322 }}$. La otra, es que nos enfrentamos a la cruda realidad "de que la tremenda y creciente distancia entre el poseedor de las armas y el desarmado nos ha llevado a vivir en un mundo en el que el temor mutuo a contiendas bélicas lo dominan todo" ${ }^{, 23}$. Estamos rodeados de armas de destrucción masiva y de campos de concentración; nos convencieron de que el progreso trae lamentablemente 'daños colaterales' que afectan a grandes contingentes de seres humanos; nos tratan de persuadir de que los muros y las fronteras son las vías más efectivas para solucionar los conflictos raciales, políticos, religiosos e, incluso, económicos.

Aunado a todo lo anterior empujan al ser humano a un suicidio planificado con el pretexto de que la 'guerra es inevitable' cuando se sabe, como señala Gadamer, que "toda la tentativa incontrolada de la humanidad de medir sus fuerzas consigo misma

${ }^{321}$ Gadamer, H-G., Arte y verdad..., op. cit., p. 111.

322 Gadamer, H-G., El giro hermenéutico, Trad. Arturo Parada, Madrid, Editorial Cátedra, 2007, p. 221.

323 Gadamer, H-G., Arte y verdad..., op. cit., p. 111. 
equivale a un intento de suicidio coronado por el éxito",324. Nada es más peligroso para la convivencia que tocar la fibra que el hombre tiene como peculiaridad: probarse a sí mismo y al mismo tiempo señalar al otro como una competencia que lo pone en desventaja en su estar en el mundo.

Aun cuando la situación se ha tornado cada vez más compleja en todos los ámbitos, una crisis como la ecológica, con cambios climáticos y afectación natural y humana, ha logrado calar en la conciencia de muchas personas abriendo tenuemente la esperanza en un mundo más a la altura de la condición humana. Este tipo de avance radicalizó aún más el sentido crítico optimista que Gadamer mantuvo hasta el final de su vida (2002). Se empeñó por esclarecer que el nudo gordiano existente sobre la «diversidad» es por una falta de convención o acuerdo de la sociedad en su conjunto a través del cual se logre un diálogo abierto y sincero sobre "la violencia de los intereses del poder económico, social, político [y] la locura de las guerras destructoras a la que pueblos son arrastrados contra pueblos”325.

El autor de Verdad y método aunque precavido de hasta dónde "la humanidad va a ser capaz de darle solución" 326 a sus inevitables problemas, insistió en un encuentro dialógico sustentado en la tolerancia, el respeto a través de la comprensión (Verständnis) que es "la facultad fundamental de la persona que caracteriza su convivencia con los demás y actúa especialmente por la vía del lenguaje y del

\section{Ibídem.}

Gadamer, H-G., Elogio de la..., op. cit., p. 58.

Gadamer, H-G., El giro hermenéutico..., op. cit., p. 221. 
diálogo, ${ }^{, 27}$. Esta facultad lleva al sujeto a expresar su verdadera humanidad y sobre todo es el camino más idóneo para alcanzar el consenso a pesar de "todas las tensiones y trastornos ${ }^{\text {”28 }}$ que se puedan dar como fruto de los diferentes horizontes en conflicto.

El encuentro en la diversidad es siempre factible porque lo atraviesa el lenguaje en sentido ontológico. El hombre es un ser que se constituye en una estructura dialógica de preguntas y respuestas. Esta posibilidad ha llevado a Gadamer a defender un optimismo antropológico, hablar del mundo habitado (oikoumene) desde el respeto, sostener que la diversidad de las lenguas no impide compartir un proyecto común e insistir que es factible construir una plataforma flexible que permita el entendimiento plural en los asuntos importantes ya que, como dice él mismo, "comprender, entender (Verstehen) es comprenderse, entenderse (Sich-Verstehen) en el mundo, 329 .

La propuesta gadameriana de fondo se basa en crear un horizonte abierto ${ }^{330}$ para que los individuos puedan vivir en un contexto donde entren todos sin utilizar la violencia como forma de dominación y como criterio definitivo de dirimir las controversias. Lo 'utópico’ de alcanzar una «lengua única» no es impedimento para comenzar a explorar la idea de concretar una «oikouménica», es decir, esa manera inmanente de estar en el mundo y de convivir con el otro en una alteridad que tienda a constituirse en una unidad.

\footnotetext{
Gadamer, H-G., Verdad y Método II..., op. cit., p. 319.

Ibíd., p. 241.

Gadamer, H-G., Arte y verdad..., op. cit., p. 121.

Cf., Ibid., p. 122.
} 
A la humanidad no le queda otro camino, según Gadamer, que aprender a comprenderse para "aplazar así la autodestrucción o evitarla incluso por medio de una constitución mundial capaz de llevar a cabo un control efectivo" ${ }^{\text {"331 }}$. Esta proposición es una constante en sus escritos esenciales y lo que nos queda finalmente es hacer una pregunta que nos ubique en el contexto ético-político del filósofo de Marburgo: ¿estamos cerca de lograr el objetivo de ponernos de acuerdo en el plano mundial? La respuesta pareciera estar enmarcada en una distanciada manera de llevar a la praxis la visión del mundo. Sólo queda, como Gadamer, seguir insistiendo hasta tener luces y logros parciales al respecto.

Pensamos que un ser humano formado bajo las premisas que ha desarrollado Gadamer basadas en la tradición humanística podría darle a la humanidad pistas válidas para su orientación ética y política ya que se sustentan en un larguísimo trayecto de saberes, vivencias múltiples $\mathrm{y}$ de experiencias afortunadas $\mathrm{y}$ desafortunadas que han sido evaluadas desde diferentes ópticas y que como un inmenso magma está allí para actualizarse creativamente.

Hemos llegado al final de una senda inspiradora trazada por Gadamer. Tratamos de explicar, a través de un enfoque político, cómo se puede encarar ciertos problemas cruciales que aquejan nuestro mundo contemporáneo desde un ser humano formado (Bildung), tal y como lo concibió Gadamer. Arribamos al convencimiento de que nuestra investigación se encuentra lejos de agotar una temática tan compleja. Con todo pensamos que la veta por donde transitamos se puede convertir en un punto de

331 Gadamer, H-G., El giro hermenéutico..., op. cit., p. 223. 
motivación o de 'provocación' para que otros incursionen en lo que consideramos uno de los aspectos de mayor actualidad en el pensamiento gadameriano. 


\section{CONCLUSIONES}

El recorrido filosófico que hemos hecho en esta investigación nos ha mostrado que el concepto de Bildung, en la perspectiva hermenéutica esgrimida por Gadamer, abriga una actualidad significativa y una trascendencia inspiradora que lo convierte en un punto de referencia válido para la comprensión de la vibrante y acelerada sociedad contemporánea y sus azarosas e impredecibles repercusiones. Se trata de una conclusión general que es fruto de un camino teórico que transitamos en tres etapas.

En la primera fase pudimos reflexionar sobre cómo deberíamos comprender el concepto de Bildung a partir de su etimología y de un estudio histórico-semántico amplio. Recurrimos al análisis detallado de R. Koselleck que nos guio para comprender el complicado concepto en sus distintas facetas históricas. Pudimos constatar, a raíz de la exposición que desarrolló este filósofo-historiador, un hecho que consideramos fundamental para la comprensión del concepto Bildung: la dificultad de ser traducido a otro idioma por lo que su sentido(s) esencial(es) sólo se circunscribiría(n) al ámbito alemán. Sin embargo, lentamente se fue abriendo el camino de utilizar el vocablo de ‘formación' como el que más se acerca al espíritu que recoge Bildung. El argumento de fondo, que esgrimieron autores como Hegel, Gadamer y el propio Koselleck, entre otros, para tomar en cuenta tal opción es que la 
formación "es una forma activa de desarrollar una vida cultivada" $" 332$ que se sustenta en una cultura que tiene su propia idiosincrasia, es decir, su forma de ser. Así, se mantiene la experiencia tradicional aportada por la sapiencia alemana (contexto, cultura y educación) pero ahora con la posibilidad de ser aplicada a otras disímiles dimensiones culturales a raíz de su carácter universal.

En esta misma línea de dilucidación de la Bildung presentamos los aportes que tanto J.G. Herder como W. Humboldt nos permitieron ubicarnos en el escenario específico alemán en el cual dicha noción germinó y se desarrolló. Por una parte Herder nos posibilitó pensar la idea de formación como un «Ascenso a la humanidad» fundado en una cultura profundamente arraigada en unos valores humanistas y en una importante dependencia al lenguaje que se caracteriza por ser una «fuerza del espíritu» ${ }^{333}$, esto es, una de las vías más expeditas que el hombre posee para desarrollar todas sus potencialidades. Vimos que estas ideas están impregnadas de una religiosidad en la que se considera que los hombres llevan en sí mismos, la imagen (Bild) de Dios que "a la luz de la verdad de la salvación, comunicada con Dios, el deseo humano de saber se consideró sospechosamente como fruto de curiositas, en virtud de la cual el hombre quería justificarse y elevarse a sí mismo"334.

En cuanto a Humboldt, hicimos patente el lugar que le atribuyó a la «lengua» en la relación hombre-mundo. Para este pensador, la Sprache es una «autoactividad» con la que el hombre, a través de la educación, constituye su hablar y pensar, vale

Koselleck, R., Historia de conceptos..., op. cit., p. 79.

Recas, J., Hacia una hermenéutica..., op. cit., p. 124.

Grondin, J., Introducción a Gadamer..., op. cit., p. 48. 
decir, su propia Bildung que lo capacita para la vida social, el diálogo con otros seres y la comprensión de su mundo.

En la segunda etapa presentamos el «recorrido del espíritu» de Hegel. Este filósofo alemán nos brindó un enfoque teórico-práctico de formación como «Ascenso a lo universal» que "significa poder contemplar las cosas desde la posición del otro" ${ }^{335}$. Esto implica un recorrido formativo amplio y de esfuerzo por parte del sujeto en su devenir, es decir, en su lucha contra las necesidades naturales que “consisten en: a) el distanciamiento respecto a la inmediatez del deseo, de la necesidad personal y del interés privado..."336 y abrirse hacia una formación teórica esto es, a la "diversidad de los conocimientos" $" 337$ entendida como una multiplicidad de saberes logrando de hecho la universalidad.

Tanto en su Fenomenología del Espíritu como en sus Escritos Pedagógicos nos muestra cómo se da este proceso formativo del hombre, a partir de una exégesis del Espíritu. Éste a partir de su inmediatez hace el recorrido como un proceso racional a través de lo que llama Hegel la Ciencia de la experiencia de la conciencia. El resultado de esta odisea es, precisamente, la formación que debe realizar cada individuo dentro de su sociedad (eticidad). Con estos aportes filosóficos de Hegel logramos conceptualizar la idea de formación y así establecimos con esta categoría correspondencia e implicaciones con las pretensiones de Gadamer de sustentar su tesis hermenéutica sobre la Bildung.

335 Gadamer, H-G., Arte y verdad..., op. cit., p. 129.

336 Conill, J., Ética hermenéutica. Crítica..., op. cit., p. 66.

337 Hegel, G.W.F., Escritos Pedagógicos..., op. cit., p. 184. 
Finalmente, en la última etapa de nuestra investigación, expusimos desde un recorrido histórico-semántico de la Bildung y un análisis tanto del sentido común (sensus communis), la capacidad de juicio como el gusto. Todos conceptos con implicaciones ético-políticas que todavía, como tratamos de mostrar, permean el mundo moderno, desde un estilo hermenéutico de vida. Un mundo en el que Gadamer visualizó tres peligros que se debían conjurar. En primer lugar, el "poder de manipulación de las ciencias a través de la fabricación"; un tema hegemónico o axial en nuestra época llena de tecnología y avances científicos que sin duda llega a proporcionar una vida más cómoda para el ser humano, pero que al mismo tiempo surge el peligro de una racionalidad instrumental con consecuencias impredecibles para la continuidad de la humanidad.

En segundo término, tenemos el problema de «la proliferación de expertos» que se presenta en la cotidianidad. Como exploramos, Gadamer cree que la distorsión de la vida humana tiene que ver con la exacerbación tecnológica o tecno-científica. Ahora bien esta crítica que hace Gadamer sobre el «experto» apunta más hacia cómo asume decisiones en un contexto determinado sin causar problemas al grupo social.

En vista de que el conocimiento del experto radica en que es exclusivamente técnico, el pensador de Marburgo se vio en la necesidad de recurrir a la autoridad, para defender tanto la tradición como la libertad. El inconveniente es que la razón no puede estar sustentada o dejada al arbitrio o exclusividad de un experto, pues para solucionar la crisis de la sociedad actual se debe partir de una razón práctica (phronēsis) que vaya más allá de un uso instrumental de la razón por especialistas. Es 
claro, para el filósofo alemán, que no necesariamente deba oponerse a la ciencia, sino que ofrezca una solución dialéctica junto a la filosofía; de lo que se trata aquí, es de coadyuvar entre sí esta problemática sustentada en el ethos humano. La utilidad del experto es importante para construir un mundo que esté acorde con las necesidades humanas, sin embargo, la cuestión de fondo es que la solución de cualquier dificultad relevante debe estar también bajo control de nuestra responsabilidad, de nuestras decisiones.

Por último, el tercer problema que Gadamer abordó es el de «la diversidad de las lenguas y la comprensión del mundo». Las exclusiones, las divisiones, las guerras, las violencias son las «Espadas de Damocles» que siempre estarán presentes tratando de minar la conciencia de la cultura occidental. Por estos motivos, Gadamer tomando en consideración el lenguaje común (koiné) o encuentro de una pluralidad de las lenguas, sostiene que los seres humanos pueden entenderse, pactar y ser conscientes de la necesidad del diálogo para evitar, en el fondo, medir fuerzas y poner en franco peligro la paz en el mundo.

Lo que propone Gadamer es el diálogo, la tolerancia que sólo se consigue con un hombre formado, vale decir, un ser humano con Bildung y de esta manera lograr un consenso que permita salir de esta crisis sin precedentes en la historia de la humanidad respecto a este asunto. El entenderse es la "realización de un diálogo 
como relación recíproca, y cuya realización está referida a la dialéctica de la pregunta y la respuesta" ${ }^{338}$.

La propuesta de Gadamer en estas circunstancias tiene que ver con entendernos unos con otros, porque es mediante el diálogo que podemos convivir en sociedad, dejando a un lado los intereses particulares y dirigiendo la vista hacia el otro, precisamente a esto apunta la idea gadameriana para una comprensión del mundo. Hemos de comentar que la "oikoumene" ese mundo habitado del que nos habló el filósofo se presenta como una proposición: es en nuestro mundo humano donde convivir es una razón urgente, donde el "lenguaje es lenguaje real cuando se trata del lenguaje realmente hablado entre dos interlocutores"339. Lo inspira el convencimiento de que "ocurre entre tú y yo la misma cosa que entre pueblos o entre los círculos culturales y comunidades religiosas" ${ }^{340}$. La tradición común occidental es la fuerza cohesionadora.

Constatamos que la idea de Bildung le ha proporcionado a Gadamer las herramientas teórico-prácticas necesarias para analizar unos problemas que están vigentes en la actualidad. De hecho, mostramos cómo a través de un análisis hermenéutico-filosófico ha podido desglosar los mecanismos de control y distorsión de tres asuntos que tienen muchas repercusiones éticas y políticas en la dinámica de la sociedad.

338 Valera, G. y Madriz, G., Una hermenéutica de la formación de sí. Lectura, escritura y experiencia, Caracas, Consejo de Desarrollo Científico y Humanístico Universidad Central de Venezuela, 2006, p. 136.

339 Gadamer, H-G., El giro hermenéutico..., op. cit., p. 223.

340 Gadamer, H-G., Arte y verdad..., op. cit., p. 125. 
Ahora bien, la pregunta que viene al caso sería: ¿qué incidencias éticas y políticas tendrán en el futuro los presupuestos hermenéuticos sugeridos por Gadamer? Después de todo lo que hemos estudiado creemos que con el concepto de la Bildung podemos seguir explorando para comprender los nuevos retos de la sociedad por venir. En otras palabras, pensamos que queda abierta la posibilidad de seguir indagando junto a Gadamer que nos advierte que "quizás no deberíamos hablar de un fin de la filosofía hasta que no se produzca un fin del preguntar. Aunque es cierto que si un día se acaba el preguntar, se habrá acabado también el pensamiento"341.

Llegamos a la confianza de la trascendencia del pensamiento gadameriano por un motivo de fondo. Pensamos que Gadamer, a través de su hermenéutica dialógica, dio en la diana al colocar la formación (Bildung) en el centro del quehacer humano. La experiencia histórica ha demostrado que si las sociedades quieren estar a la altura de sus permanentes desafíos o demandas, deben contar con individuos preparados no solamente en los escalonados niveles académicos sino sobre todo en el dominio de unos comportamientos y valores orientados tanto al perfeccionamiento personal como a la convivencia humana y al bien común. Estas exigencias históricas se hacen más perentorias en los tiempos que vendrán.

Nos encontramos en una época de transición o ansiosa de permearse de un nuevo paradigma. Está signada por cambios profundos de la forma de vida, por contactos humanos efímeros enmarcados en medios masivos persuasivos, por el trastrocamiento permanente tanto de los parámetros institucionales como de la escala

341 Gadamer, H-G., El giro hermenéutico..., op. cit., p. 238. 
de valores y, finalmente por el auge incontenible del desencanto y del escepticismo. Todo esto acompañado con el estribillo de que estamos viviendo en una crisis de magnitudes insospechadas que solamente los 'expertos' en economía y los 'espantadores de conflictos' estarían en capacidad de conjurar eficientemente. Es precisamente en estas condiciones que nos envuelven, desorientan y en las que se vislumbran cosas peores en donde entra Gadamer con una opción válida respaldada por una Bildung políticamente inspiradora.

Pensamos que la Bildung gadameriana es una «fuente siempre viva» a la que se puede abrevar en esos momentos en los que es difícil establecer los ajustes necesarios entre lo universal y lo particular, entre el antes y el ahora, entre lo aprendido y lo que está por aprender, entre la teoría y la práctica, entre la desesperación y la esperanza. De hecho, su influjo queda patente en la gran cantidad de ensayos, libros, tesis de grado que expanden sus implicaciones o riquezas teóricas. Pero lo más importante se da en el plano de la aplicación. Son muchas las experiencias educativas y sociales que se han llevado a cabo, a nivel mundial, a partir de lo que la Bildung gadameriana ha inspirado.

En esta Bildung encontramos una concepción ontológica del lenguaje que increpa a todas esas consejas que se empeñan en cerrar las opciones de diálogo o que enfatizan más las diferencias que lo que une. Para Gadamer existe una especie de imperativo moral: "aprender a reconocer en el otro y en la diferencia lo común"342.

342 Ibíd., p. 186. 
También en la Bildung hallamos, a raíz del sentido común (lo heredado), la capacidad de juicio (lo adquirido) y el gusto (lo refinado), un potencial crítico que permanentemente deberá ser puesto en práctica en variables situaciones. Para Gadamer, mientras nos mantengamos dentro de «lo humano y lo digno» que se fue fraguando gracias al concurso de diferentes culturas, no todo puede ser 'tragado', no todo debe ser aceptado impunemente, no todo vale aunque muchos se empeñen en afirmarlo. No obstante que las nuevas realidades se impongan arrolladoramente, no se puede ceder, nos dirá el filósofo, sin antes evaluar si tanto los individuos como las sociedades expanden lo mejor de sus virtualidades.

Podríamos decir que Gadamer sintetiza su optimismo radical u ontológico en su 'fe' en la Bildung o en la formación del hombre. Pero no se trata, como mostramos, de una posición ingenua o de espaldas a los apremiantes problemas, que en todos los órdenes, envuelven a occidente. Se encamina, más bien, a mostrar que "lo negativo no debe callarse" ${ }^{\text {343 }}$ y que siempre es necesario y posible la apertura al otro. Su hermenéutica se expande para colmar ambas aspiraciones con la salvedad de que nunca será de manera definitiva. En tal sentido, el compromiso central al que nos convoca este insigne filósofo es saber «oír» (hören) porque esto supone la ampliación de horizontes en el reconocimiento del mutuo pertenecer (gehören), en un mundo de la vida (Lebenswelt).

343 Dutt, C., En conversación con..., op. cit., p. 103. 


\section{BIBLIOGRAFÍA}

1. Baur, Ernest, Juan Godofredo Herder. Su vida y su obra, Trad. Agustín García Calvo, Madrid, Editorial Tecnos, 1968.

2. Beiner, Ronald, El juicio político, Trad. Juan José Utrilla, México, Fondo de Cultura Económica, 1987.

3. Berlin, Isaiah, Vico y Herder. Dos estudios en la historia de las ideas, Trad. Carmen González del Tejo, Madrid, Editorial Cátedra, 2000.

4. Bueno, Gustavo, El mito de la cultura. Ensayo de una filosofía materialista de la cultura, Barcelona, Editorial Prensa Ibérica, 2004.

5. Collingwood, Robin George, Idea de la historia, México, Fondo de Cultura Económica, 2004.

6. Conill, Jesús, Ética hermenéutica. Crítica desde la facticidad, Madrid, Editorial Tecnos, 2010.

7. Copleston, Frederick, Historia de la filosofía 7: de Fichte a Nietzsche, Trad. Ana Domènech, Barcelona, Editorial Ariel Filosofía, 2004.

8. Cordua, Carla, El Mundo ético, Ensayos sobre la esfera del hombre en la filosofía de Hegel, Barcelona, Editorial Anthropos, 1989.

9. Crelier, Andrés, Introducción a la filosofía Hermenéutica del Lenguaje, Buenos Aires, Editorial Biblos, 2013.

10. Dieter, Koniecki y Almarza, Juan, (Coord), "El pensamiento alemán contemporáneo, Hermenéutica y teoría crítica", en Almarza, Juan, H.G. 
Gadamer: La historicidad de la comprensión. Fundamentos para una teoría de la experiencia hermenéutica, Salamanca, Editorial San Esteban, 1985.

11. Dutt, Carsten, (edit.), En conversación con Hans-Georg Gadamer. Hermenéutica, estética, filosofía práctica, Trad. Teresa Rocha Barco, Madrid, Editorial Tecnos, 1998.

12. Fink, Eugen, Hegel. Interpretaciones fenomenológicas de la Fenomenología del Espíritu, Trad. Iván Ortega Rodríguez, Barcelona, Editorial Herder, 2011.

13. Freund, Julien, Las teorías de las ciencias humanas, Barcelona, Ediciones Península, 1993.

14. Gadamer, Hans-Georg, La razón en la época de la ciencia, Trad. Ernesto Garzón Valdés, Barcelona, Editorial Alfa, 1981.

15. Gadamer, Hans-Georg, La herencia de Europa, Trad. Pilar Giralt Gorina, Barcelona, Ediciones Península, 1990.

16. Gadamer, Hans-Georg, La Dialéctica de Hegel. Cinco ensayos hermenéuticos, Trad. Manuel Garrido, Madrid, Editorial Cátedra, 1994.

17. Gadamer, Hans-Georg, La Educación es Educarse, Trad. Francesc Pereña Blasi, Barcelona, Ediciones Paidós Ibérica, S.A., 2000.

18. Gadamer, Hans-Georg, Acotaciones hermenéuticas, Trad. Ana Agud y Rafael de Agapito, Madrid, Editorial Trotta, 2002.

19. Gadamer, Hans-Georg, Verdad y Método II, Trad. Manuel Olasagasti, Salamanca, Ediciones Sígueme, 2006. 
20. Gadamer, Hans-Georg, Verdad y Método I, $3^{\mathrm{a}}$ ed., Trad. Ana Agud Aparicio y Rafael de Agapito, Salamanca, Ediciones Sígueme, 2007.

21. Gadamer, Hans-Georg, El giro hermenéutico, Trad. Arturo Parada, Madrid, Editorial Cátedra, 2007.

22. Gadamer, Hans-Georg, El problema de la conciencia histórica, Trad. Agustín Domingo Moratalla, Madrid, Editorial Tecnos, 2007.

23. Gadamer, Hans-Georg, Arte y verdad de la palabra, Trad. José Francisco Zuñiga y Faustino Oncina, Barcelona, Ediciones Paidós Ibérica, S.A., 2009.

24. Gadamer, Hans-Georg, Elogio de la teoría, Trad. Luis Martínez, Barcelona, Editorial RBA Libros, S.A., 2013.

25. Gracián, Baltasar, El criticón, Tom. I, Madrid, Editorial Espasa-Calpe, 1971.

26. Grondin, Jean, Introducción a Gadamer, Trad. Constantino Ruiz-Garrido, Barcelona, Editorial Herder, 2003.

27. Grondin, Jean, Introducción a la hermenéutica filosófica, Trad. Ángela Ackermann Pilári, Barcelona, Editorial Herder, 2002.

28. Grondin, Jean, ¿Qué es la hermenéutica? Trad. Antoni Martínez Riu, Barcelona, Editorial Herder, 2008.

29. Gutiérrez, Carlos, Ensayos hermenéuticos, México, Ediciones Siglo XXI, 2008.

30. Hegel, G.W.F., Filosofía del Derecho, Trad. Eduardo Vásquez, Caracas, Ediciones de la Biblioteca de la Universidad Central de Venezuela, 1976.

31. Hegel, G.W.F., El sistema de la Eticidad, Trad. Luis González-Hontoria, Madrid, Editora Nacional, 1982. 
32. Hegel, G.W.F., Lecciones de filosofía de la religión, Vol. 3, Trad. Ricardo Ferrara, Madrid, Alianza Universidad, 1987.

33. Hegel, G.W.F., Escritos de juventud, Trad. Zoltan Szankay y José María Ripalda, México, Fondo de Cultura Económica, 1989.

34. Hegel, G.W.F., Diferencia entre los sistemas de la filosofía de Fichte y Schelling, Trad. Ma del Carmen Paredes Martín, Madrid, Editorial Tecnos, 1990.

35. Hegel, G.W.F., Escritos Pedagógicos, Trad. Arsenio Ginzo, México, Fondo de Cultura Económica, 1998.

36. Hegel, G.W.F., Lecciones sobre la filosofía de la Historia Universal, Trad. José Gaos, Madrid, Alianza Editorial, 2004.

37. Hegel, G.W.F., Fenomenología del Espíritu, $4^{\mathrm{a}}$ ed., Trad. Wenceslao Roces y Ricardo Guerra, México, Fondo de Cultura Económica, 2006.

38. Heidegger, Martin, La Fenomenología del Espíritu de Hegel, Trad. Manuel E. Vásquez y Klaus Wrehde, Madrid, Alianza Editorial, 2012.

39. Herder, Johann, Ideas para una filosofía de la historia de la humanidad, Trad. Rovira Armengol, Buenos Aires, Editorial Losada, 1959.

40. Höffe, Otfried, Immanuel Kant, Trad. Diorki, Barcelona, Editorial Herder, 1986.

41. Horlacher, Rebekka, “¿Qué es Bildung? El eterno atractivo de un concepto difuso en la teoría de la educación alemana", en Pensamiento Educativo, Revista de Investigación Educacional Latinoamericana, 2014, Chile, pp. 35-45. 
42. Humboldt, Wilhelm (von), Escritos sobre el lenguaje, Trad. Andrés Sánchez Pascual, Barcelona, Ediciones Península, 1991.

43. Hyppolite, Jean, Génesis y Estructura de la Fenomenología del Espíritu de Hegel, Trad. Francisco Fernández Buey, Barcelona, Ediciones Península, 1974.

44. Jaeger, Werner, Paideia, Los ideales de la cultura griega, Trad. Joaquín Xirau y Wenceslao Roces, México, Fondo de Cultura Económica, 2001.

45. Kant, Immanuel, Critica de la facultad de juzgar, Trad. Pablo Oyarzún, Caracas, Monte Ávila Editores, 2006.

46. Karczmarczyk, Pedro, Gadamer: aplicación y comprensión, Buenos Aires, Editorial de la Universidad Nacional de la Plata, 2007.

47. Koselleck, Reinhart y Gadamer, Hans-Georg, Historia y hermenéutica, Trad. Faustino Oncina, Barcelona, Ediciones Paidós Ibérica, 2006.

48. Koselleck, Reinhart, Historias de conceptos. Estudios sobre semántica y pragmática del lenguaje político y social, Trad. Luis Fernández Torres, Madrid, Editorial Trotta, 2012.

49. Lafont, Cristina, La razón como lenguaje, una revisión del giro lingüístico en la filosofía del lenguaje alemana, Madrid, Editorial Visor S.A., 1993.

50. Leroy, Maurice, Las grandes corrientes de la lingüística, Madrid, Fondo de Cultura Económica, 1974.

51. Lulo, Julio, "La vía hermenéutica: Las ciencias sociales entre la epistemología y la ontología”, en Schuster, Federico, (Comp.), Filosofía y métodos de las Ciencias Sociales, Buenos Aires, Editorial Manantial, 2011. 
52. Marcuse, Herbert, Razón y Revolución. Hegel y el surgimiento de la teoría social, Trad. Julieta Fombona de Sucre y Francisco Rubio Llorente, Madrid, Alianza Editorial, 1976.

53. Martínez, Felipe, Historia de la Filosofía, Madrid, Ediciones Istmo, 1973.

54. Marx, Karl y Engels, Friedrich, Manifiesto comunista, Trad. Pedro Ribas, Madrid, Alianza Editorial, 2007.

55. Másmela, Carlos, Hegel: La desgraciada reconciliación del espíritu. Madrid, Editorial Trotta, S. A., 2001.

56. Nancy, Jean, Hegel. La inquietud de lo negativo, Trad. Juan Manuel Garrido, Madrid, Editorial Arena Libros S. L., 2005.

57. Navas, Nowys, "Phrónesis y Hermenéutica", en Apuntes Filosóficos UCV, Vol. 21, No 40, Caracas, 2012, pp. 67-86.

58. Palmier, Jean, Hegel, Trad. Juan José Utrilla, México, Fondo de Cultura Económica, 2006.

59. Reale, Giovanny, Introducción a Aristóteles, Trad. Víctor Bazterrica, Barcelona, Editorial Herder, 1992.

60. Recas, Javier, Hacia una hermenéutica crítica, Gadamer, Habermas, Apel, Vattimo, Rorty, Derrida y Ricoeur, Madrid, Editorial Biblioteca Nueva S.L., 2006.

61. Ríos, Clara, "Un acercamiento al concepto de formación en Gadamer", en Revista de Educación y pedagogía, N 15-16, Medellín, 1995, pp. 15-35. 
62. Rodríguez, Adriana, Identidad lingüística y nación cultural en J.G. Herder. Madrid, Editorial Biblioteca Nueva S.L., 2008.

63. Sánchez, Ángel, Introducción a la Ética y a la crítica de la Moral, Caracas, Vadell Hermanos Editores, 2009.

64. Sánchez, Ricardo, “¿La Fenomenología del Espíritu como Bildungsroman?”, en Eikasia Revista de Filosofía, año III Vol. 15, Valladolid, Diciembre del 2007, pp. 99-112.

65. Sianes, Alicia, “Bildung”: Concepto, evolución e influjo en la pedagogía occidental desde una perspectiva histórica y actual”, en Revista española de educación comparada, $\mathrm{N}^{\circ}$ 30, Julio-diciembre, 2017, pp. 99-111.

66. Valcárcel, Amelia, Hegel y la Ética. Sobre la superación de la «Mera Moral», Barcelona, Editorial Anthropos, 1998.

67. Valera, Gregorio y Madriz, Gladys, Una hermenéutica de la formación de sí. Lectura, escritura y experiencia, Caracas, Consejo de Desarrollo Científico y Humanístico Universidad Central de Venezuela, 2006.

68. Vásquez, Eduardo, Ensayos sobre la dialéctica de Hegel, Estudios sobre la dialéctica en Hegel y Marx, Caracas, Universidad Central de Venezuela, 1982.

69. Vásquez, Eduardo, Ciencia y dialéctica, Guarenas, Fondo Editorial el Búho de Minerva, 1988.

70. Vásquez, Eduardo, Filosofía y Educación, Mérida, Consejo de publicaciones Universidad de los Andes, 1994. 
71. Vásquez, Eduardo, Hegel un desconocido, Mérida, Consejo de publicaciones Universidad de los Andes, 1998.

72. Vilanou, Conrad, "Formación, cultura y hermenéutica", en Revista de Educación, № 328, Barcelona, 2002, p. 206.

73. Walsh, William Henry, Introducción a la filosofía de la historia, México, Siglo XXI Editores, 1980. 


\section{BREVE BIOGRAFÍA}

\section{Luis Enrique Silva Viera. Currículo}

Luis Enrique Silva Viera. Profesor de Filosofía de la Universidad Pontificia Católica Santa Rosa. Caracas-Venezuela.

E-mails: novalisucv@gmail.com / filosofiaucv@gmail.com

Licenciado en Filosofía (2009), Licenciado en Educación: Mención Filosofía (2012), MSc. En Filosofía: Mención Filosofía y Ciencias Humanas (2019) Todos los estudios realizados en la Universidad Central de Venezuela. Actualmente realiza estudios de Maestría en Teología Dogmática por la Universidad Pontificia Católica Santa Rosa Caracas-Venezuela. Ponencias: Disertación sobre Karl Marx: La selva, La alienación del hombre, una interpretación. Disertación sobre Hegel: "La unidad dialéctica en la conciencia. La certeza Sensible en la Fenomenología del Espíritu de Hegel." Disertación: La filosofía de la reflexión en Hegel una aproximación a "Fe y Saber". Disertación: Charles Taylor: La noción de reconocimiento e identidad.

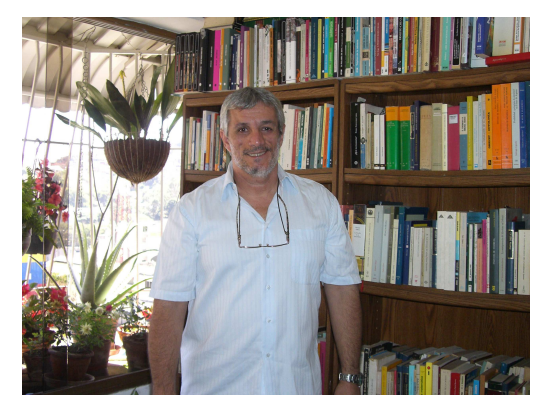

